\title{
Did ECB Liquidity Injections Help The Real Economy?*
}

\author{
Stine Louise Daetz \\ Danmarks Nationalbank \& Copenhagen Business School \\ E-mail: sld.fi@cbs.dk \\ Marti G. Subrahmanyam \\ Stern School of Business, New York University \\ E-mail: msubrahm@stern.nyu.edu \\ Dragon Yongjun Tang \\ Faculty of Business and Economics, University of Hong Kong \\ E-mail: yjtang@hku.hk \\ Sarah Qian Wang \\ Warwick Business School, University of Warwick \\ E-mail: qian.wang@wbs.ac.uk
}

September 22, 2017

\footnotetext{
${ }^{*}$ For helpful comments and discussions, we thank Viral Acharya, Michele Boldrin, Murillo Campello, David Cook, Xiaodan Gao, Gary Gorton, Regina Hammerschmid, Balint Horvath, Nigel Jones Barradale, Raj Iyer, Andrew Karolyi, Andrew MacKinlay, Simone Manganelli, Martin Oehmke, Davide Tomio, Neeltje Van Horen, Yan Xu, and seminar and conference participants at the Reserve Bank of Australia, Shanghai Advanced Institute of Finance Shanghai Jiao Tong University, the Chinese University of Hong Kong, University of Macau, the Hong Kong Polytechnic University, Cass Business School, Copenhagen Business School, NYU Stern, Bocconi University, University of Warwick, University of Surrey, Goethe University of Frankfurt, the CICF 2017, FMA Asia 2017, The 4th International Conference on Sovereign Bond Markets, the conference on "Asymmetries in Europe: Causes, Consequences, and Remedies" in Pescara, Swiss Society for Financial Market Research 2017, Bank of Canada Annual Conference 2016, European Banking Center Network Conference 2016, 15th International Conference Credit, 6th IWH/INFER Workshop on (Ending) Unconventional Monetary Policy, EFA 2016, Indian School of Business (ISB) Summer Research Conference, IF2016 Annual Conference in International Finance at City University of Hong Kong, and the 2016 FEBS Conference. We also acknowledge the support of Research Center SAFE at Goethe University, Marcel Heinrichs from S\&P Capital IQ, and Matteo Crosignani for helping us with data. Daetz gratefully acknowledges support from the Center for Financial Frictions (FRIC), grant no. DNRF102. Subrahmanyam thanks the Volkswagen Foundation, the Anneliese Maier Research Award of the Alexander von Humboldt Foundation, and the Center for Global Economy and Business at NYU Stern for their generous support. Disclaimer: The views expressed in this paper are those of the authors and do not necessarily reflect the position of Danmarks Nationalbank.
} 


\title{
Did ECB Liquidity Injections Help The Real Economy?
}

\author{
Abstract \\ We investigate the corporate-level efficacy of unconventional monetary interventions using \\ Longer-Term Refinancing Operations (LTROs), through which the European Central Bank pro- \\ vided long-term funds to banks. We find that Eurozone corporations did not increase invest- \\ ments even when their banks retained LTRO funds for a long period. However, counterfactual \\ analysis suggests that LTROs helped Eurozone corporations sustain their investments better \\ than European corporations outside the Eurozone. The LTROs were more effective in countries \\ with accommodative fiscal policies. Our findings demonstrate that monetary interventions help \\ decelerate economic decline, but also reveal the difficulty of boosting investments by injecting \\ liquidity into the banking system.
}




\section{Introduction}

Since the summer of 2009, the European Central Bank (ECB) has been engaged in a series of both conventional and, more recently, unconventional monetary policy actions, such as injecting liquidity into the banking system through Longer-Term Refinancing Operations (LTROs). These liquidity injections were of significant size and scope. However, the important question of whether these liquidity injections have helped the real economy as intended remains unanswered. Despite the overwhelming press coverage on this topic, the literature has primarily focused on the impact of the ECB's unconventional monetary policy on the banking sector and its related financial ramifications. There is still a lack of evidence on the changes that occurred in corporate financial and operating policies in the Eurozone following ECB liquidity injections; those changes have implications for the real effects of monetary policy. In this paper, we fill this gap in the literature by examining the impact of unconventional liquidity interventions on corporate policies, in a unified framework, including cash holdings, financing, investment, and employment. This research on the real effects of liquidity injections is of considerable importance, as many central banks around the world are still actively and regularly employing this approach in an effort to stimulate their economies, whereas others are planning to phase them out.

The Eurozone, and Europe at large, has faced serious fiscal challenges at least since April 2010, when Greece requested emergency funds from the European Union (EU), the International Monetary Fund (IMF), and the ECB. These fiscal problems caused substantial stress in the financial markets, which has spread to the Eurozones peripheral countries (e.g., Ireland, Italy, Portugal, and Spain) and even threatened its core. As a reaction to heightened sovereign bond yields and the looming European Sovereign Debt Crisis, the EU, the IMF, and the ECB engineered a series of interventions to improve market liquidity, real output, and employment. However, the efficacy of these measures remains hotly debated. One prominent example of these interventions is the liquidity injected by the ECB into the commercial banks of Eurozone countries through two unconventional LTROs with a three-year maturity, implemented in December 2011 and February 2012, respectively. ${ }^{1}$

\footnotetext{
${ }^{1}$ Subsequently, the ECB announced in June 2014 that it would conduct a series of targeted LTROs (TLTROs), through which permitted additional borrowing amounts would be linked to banks' lending to the non-financial sector, such that their operations became even more directed towards their final goal, i.e., that of overcoming financing difficulties at the corporate and household levels. We discuss ECB interventions in more detail in the second section.
} 
The extant discussion on the effect of market liquidity interventions, both in policymaking circles and in the academic literature, has focused mainly on the overall market reactions, e.g., bond yields, market liquidity, or how the interventions affected financial institutions. Correspondingly, the final goal of boosting both corporate liquidity and the real economy has not been analyzed in any depth at the Eurosystem level. Theoretically, macro-liquidity injections do not always translate into corporate liquidity and investment (e.g., Christiano (1994)). Banks' lending to corporations may respond weakly to liquidity interventions because of their precautionary motive to deleverage, particularly when banks hold large amounts of risky sovereign debt (Bocola (2016)). Furthermore, unconventional liquidity interventions can affect the real economy not only through bank lending to corporations but also through corporations' own liquidity, financing, and investment policies. Unconventional monetary policies may boost bank liquidity, making it less necessary for corporations to hold more precautionary cash. However, banks may use lender-of-last-resort (LOLR) funding from central banks to take on more sovereign risk rather than lend to corporations. Such risk taking by banks through their lending may further accentuate corporate precautionary motives for holding cash. As a result, corporations may save more cash from their operating cash flows, or even borrow more and save the proceeds as cash holdings. Corporations may even decrease their risky investments and switch to safer cash-equivalent holdings, such as short-term sovereign instruments. In addition, although macro-liquidity injections can relax corporate financing constraints in a particular region, corporate investment may decrease because of a sharp decline in demand from other regions. Overall, it is unclear whether we would observe a positive effect of liquidity injections on the real economy. ${ }^{2}$

In this paper, we explicitly address this lacuna in the literature and investigate whether particular ECB liquidity injections helped the real economy. Specifically, we examine the impact of macro-liquidity injections on corporate policies in the context of the ECB's LTROs I and II, as exogenous liquidity shocks in Eurozone countries. The ECB's liquidity injections provide an ideal setting for conducting a cross-country study of corporations' response to macro-liquidity interventions in view of both the heterogeneity of economic conditions across the Eurozone and the differing responses of each country's banks to ECB policies. Although prior studies show that negative credit

\footnotetext{
${ }^{2}$ There is a substantial degree of disagreement among business economists about the real effects of such liquidity injections. For example, the Spanish bank BBVA expresses a more optimistic view and argues that ECB liquidity injections could boost Eurozone GDP by between $0.3 \%$ and $0.5 \%$.
} 
supply shocks result in reduction in investments (e.g., Chava and Purnanandam (2011)), it is unclear whether a positive credit supply shock can boost investment, since corporations do not base their investment decisions exclusively on their cost of funding: New investments tend to be driven by long-term plans, not short-term considerations.

We use a comprehensive dataset that combines monetary policy data from the ECB Statistical Warehouse, loan information on Euro-area lenders from Thomson Reuters Loan Pricing Corporation (LPC) DealScan database, corporate fundamental data from Compustat Global and S\&P Capital IQ, credit rating data on non-financial corporations from CreditPro ${ }^{\circledR}$ by S\&P Capital IQ, credit default swaps (CDS) data from Markit, and relevant data from other sources. We find that corporations increased their cash holdings following ECB liquidity injections both at the time of their announcement and during the programs' subsequent implementation. We also confirm that this increase in cash holdings is statistically significant for Eurozone corporations. Our evidence suggests that corporations seem to raise debt from Eurozone banks (and probably also the public bond market) and hoard the resulting cash receipts. This cash increase is related to the banks actual uptake under the LTRO program in the same country, thus demonstrating the effects of the liquidity injection.

Nevertheless, we find a negative association between the LTRO uptake of banks and corporate investments in a given country (whereas there is no significant change in corporate payments to employees). Specifically, we find that corporations in countries with a higher LTRO uptake experienced large investment cuts; furthermore, corporations associated with banks with a higher LTRO uptake reduced investments more than those associated with a lower LTRO uptake. These results suggest that the increase in corporate liquidity may not have been employed in a productive manner. However, investments may reflect other influences such as the health of the banking system or macro-economic demand in the country. In relation to this discussion, we also note that we do not claim that unconventional LTROs caused the decrease in investments; rather, we argue that LTROs alone were not enough to boost corporate investments in the face of broader economic conditions. Indeed, the counterfactual evidence is that the two three-year LTROs seemed to have halted the deterioration in investments, as evidenced by the fact that non-Eurozone corporations in Europe experienced even larger investment cuts post-LTRO.

A noteworthy feature of LTROs is that some banks repaid the ECB's LTRO loans rather quickly, 
whereas others kept the money for a longer time. We find that when banks kept the LTRO funds for a longer time, corporations generally had higher cash holdings, but did not increase or decrease investment. Meanwhile, we find the investment reduction associated with LTROs to be mainly driven by corporations in countries with intermediate LTRO repayments. In contrast, corporations associated with banks that made faster repayments, i.e., German corporations, experienced an increase in investments. Overall, these findings reveal the interesting distributional effects of unconventional monetary policies and cast doubt on the real beneficiaries of the liquidity injection in that the countries that were the most affected by the Eurozone crisis did not experience an improvement in investment.

Recent discussions of macro-economic interventions in the face of anemic economic growth have shifted to fiscal policies after many years of monetary easing. In a monetary union such as the Eurozone, individual governments can (and often do) take different actions, which are sometimes unrelated to ECB policies. We investigate the effects of these policies and show that when individual governments cut corporate taxes or increased public investments, the LTRO uptake is associated with an increase in investments. These findings demonstrate the importance of coordinated monetary and fiscal policies to corporate investments, as there are limits to the efficacy of monetary policies in isolation.

Most studies on unconventional monetary policies are based on the U.S. experience (e.g., Berger and Roman (2016)). The paper by Acharya, Eisert, Eufinger, and Hirsch (2016) is among the few studies of Europe. On the one hand, our findings are consistent with that paper: both studies find that European corporations hold more cash after an exogenous liquidity shock. On the other hand, we focus on corporations' decisions and financing methods. Their research finds that corporations mostly save cash out of their free cash flows, whereas for our sample corporations, the primary sources of increased cash holdings are bank loans. We also argue that ECB liquidity injections have been ineffective in boosting corporate investments. Nevertheless, we show that those liquidity injections may have halted economic deterioration in the Eurozone. Furthermore, we suggest that it is important to consider monetary policies in tandem with fiscal policies. Finally, we show that it is important to consider cross-country heterogeneity in examining the effects of liquidity injections because not all countries react in the same manner to the coordinated unconventional monetary policies at the Eurosystem level. 
The rest of the paper proceeds as follows. We discuss the background and related literature in the next section. Section 3 provides descriptive statistics for our data and specifies the empirical setting for our analysis. In section 4, we investigate the impact of macro-liquidity injections on major corporate policies. In section 5, we examine the asymmetries in the LTRO impact across firms and countries. Section 6 concludes.

\section{Institutional Background and Related Literature}

A substantial body of literature has shown that negative credit supply shocks reduce corporate investments. Amiti and Weinstein (2017) show that supply-side financial shocks have a large impact on corporate investment. Chodorow-Reich (2014) shows that credit market disruptions in 20082009 caused a significant decrease in employment. Cingano, Manaresi, and Sette (2016) use Italian data to show that the liquidity drought in the interbank market during the 2007 crisis caused a large investment decrease. Bottero, Lenzu, and Mezzanotti (2017) show that investment and employment of small corporations in Italy were negatively affected by the credit crunch that followed the Greek crisis. De Marco (2017) shows that during European sovereign debt crisis, banks cut the credit supply because of their own funding problems, and corporations subsequently decreased their investments. Buca and Vermeulen (2017) show that European corporations substantially reduced their investments during the sovereign debt crisis after bank credit tightening. There is little prior research on whether a positive credit supply shock can boost investment. ${ }^{3}$ Therefore, we aim to understand the impact of monetary stimulus on corporate investments.

Central banks play an active and prominent role in the financial markets, and their actions can profoundly affect corporate policies. It is fundamentally important to understand the impact of monetary policy. Although there is substantial research on the conventional monetary policies of the U.S. Federal Reserve System (e.g., Gorton and Metrick (2013), and Romer and Romer (2013)), there is little research on unconventional monetary policies, non-U.S. policies, and their impact on the real economy. After the global financial crisis and the great recession that ensued, mon-

\footnotetext{
${ }^{3}$ One exception is Kasahara, Sawada, and Suzuki (2016), who show that capital injections made by the Japanese government in March 1998 and 1999 had a negligible impact on the average investment rate. Bergman, Iyer, and Thakor (2017) find a positive effect of cash injection during the Farm Debt Crisis of the 1980s. Chakraborty, Goldstein, and MacKinlay (2017) find that corporations reduce their investments when their banks receive a monetary stimulus. Foley-Fisher, Ramcharan, and Yu (2016) find that non-financial corporations that were more dependent on longerterm debt increased their investment during the Maturity Extension Program (MEP).
} 
etary interventions were first initiated by the U.S. government and the Federal Reserve System, leading to several studies examining U.S. data. In general, those studies find some evidence of banks increased risk shifting, relaxed corporate financing constraints, and an ineffective impact on households following the interventions. For example, Duchin and Sosyura (2015) and Berger and Roman (2016) focus on the Troubled Asset Relief Program (TARP) and find evidence of regulatory arbitrage by banks and a positive impact on "Main Street" after the program. Agarwal, Chomsisengphet, Mahoney, and Stroebel (2015) find that government interventions aimed at lowering banks' funding costs are ineffective in terms of stimulating household borrowing and spending. Furthermore, the impact of the interventions on the real economy, such as corporate financing constraints and investments, may depend on the characteristics of the intervention. For example, Chakraborty, Goldstein, and MacKinlay (2017) find that the mortgage-backed securities (MBS) purchases made by the Federal Reserve may crowd out banks' commercial lending and decrease corporate investment. However, they do not find the same effects for Treasury purchases.

The ECBs introduction of unconventional monetary policies in Europe led to similar studies based on European data. Studies on European policies are particularly important, as Europe has a very different governance structure than the U.S., particularly with regard to economic affairs; this implies that the U.S. analysis may not apply in a straightforward way. The crucial difference lies with the common monetary policy in the Eurozone, even as member countries follow independent fiscal policies. A number of the European studies focus on the sovereign bond market and banks' risk taking after either the announcement or the actual implementation of unconventional monetary policies. Eser and Schwaab (2016) find that the SMP helped lower the yield spreads and yield volatilities of European sovereign bonds. Although Acharya, Imbierowicz, Steffen, and Teichmann (2015) do find some announcement effects, they note that it was actual purchases and not the signaling of the policy that drove the lower bond yields. De Pooter, Martin, and Pruitt (2016) find consistent results demonstrating that the SMP helped lower the sovereign bond liquidity premium. Garcia-de Andoain, Heider, Hoerova, and Manganelli (2016) find that ECB liquidity injections helped stabilize the overnight unsecured interbank market. Drechsler, Drechsel, Marques-Ibanez, and Schnabl (2016) find that banks with weaker capitalization borrowed from the ECB and posted riskier collateral to access ECB funding. Acharya and Steffen (2015) also document banks' "carry trade" behavior from 2007 to 2013 and attribute it to risk shifting and regulatory arbitrage motives. 
Acharya, Pierret, and Steffen (2016) find different effects from the LTRO and OMT on banks' risk taking. Whereas the LTROs increased banks' holding of risky sovereign debt, the OMT reduced sovereign risk and increased banks' debt holdings. De Pooter, DeSimone, Martin, and Pruitt (2015) find SMP announcement effects but no actual purchase effect on bond yield spreads. Pelizzon, Subrahmanyam, Tomio, and Uno (2016) investigate the dynamic relationship between sovereign credit risk and sovereign bond market liquidity. They find that a change in sovereign credit risk leads a change in market liquidity. However, the ECB intervention weakened this adverse relationship and improved market liquidity. Trebesch and Zettelmeyer (2016) investigate the determinants and effects of ECB interventions on the Greek government bond market in mid-2010. They find that bonds bought by the ECB experienced a much steeper drop in their yields than did other bonds.

In addition to the sovereign bond market and banks' risk taking, an increasing number of papers focus on the impact of unconventional monetary policies on the actual users of capital, i.e., corporations, which are this studys focus. In this regard, Acharya, Eisert, Eufinger, and Hirsch (2017) show that banks increased their lending to corporations following the "whatever-ittakes" statement of ECB President Mario Draghi and the announcement of the OMT. However, these corporations used the funds to build up their cash reserves rather than to increase their investment or employment. Acharya, Eisert, Eufinger, and Hirsch (2016) show that the contraction in the loan supply from Eurozone periphery banks that arose during the financial crisis from 2006 to 2012 depressed investment, job creation, and sales among related European borrowers, concluding that the borrowers saved more cash out of their free cash flows. Similarly, ChodorowReich (2014) documents the negative impact of bank lending frictions on employment outcomes. Acharya, Imbierowicz, Steffen, and Teichmann (2015) investigate the transmission of the liquidity interventions of central banks to the bank deposits and loan spreads of European corporations. They find differing transmissions of central bank liquidity for low-risk banks compared to that of high-risk banks and an impaired transmission from high-risk banks to corporate borrowers. Carpinelli and Crosignani (2017) also examine the LTRO but use only data from Italian banks. They highlight the important role of collateral for the transmission of unconventional monetary policies. Garcia-Posada and Marchetti (2016) analyze the real effect of the LTRO on Spanish corporations and find that it had a positive, moderately sized effect on the supply of bank credit to corporations, providing evidence of a bank lending channel in the context of unconventional 
monetary policies. Andrade, Cahn, Fraisse, and Mésonnier (2015) analyze the LTROs impact in France and find that they increased the supply of loans to French corporations. In contrast to much of the prior literature, we provide a comprehensive examination of corporations in the Eurozone as a whole and examine the effects on corporate financial policies in a more detailed and comprehensive manner.

Our paper relates to the above literature and adds new and more granular results to the literature on corporate liquidity and investment management. ${ }^{4}$ As outlined by Bolton, Chen, and Wang (2014), corporations that face external financial frictions need to use their liquidity reserves (such as cash holdings) to service outstanding debt. In another paper, Bolton, Chen, and Wang (2013) argue that when market conditions are good or corporations face significant uncertainties in their future financing conditions, they may issue new equity or debt and hoard the proceeds as cash, even if there is no immediate use for the funds. Similarly, Bocola (2016) emphasizes the role of the precautionary motive in crises and exemplifies it in a theoretical model for the case of the LTRO intervention. Subrahmanyam, Tang, and Wang (2017) find that the inception of CDS trading increases corporate precautionary cash holdings, which is partly financed by increases in debt financing. Iyer, Peydro, da Rocha-Lopes, and Schoar (2014) also provide evidence of "liquidity hoarding" during the 2007-2009 crisis. Kahle and Stulz (2013) show that bank-dependent corporations hoarded cash during the global financial crisis. All these papers outline the importance of cash holdings for corporate liquidity management and show that corporations do adjust their internal liquidity with respect to the availability of external funding.

Another related area of the literature tackles the determinants of corporate investment, including corporate taxation and other factors. For instance, Graham, Leary, and Roberts (2014) study U.S. data and find that government fiscal activities can affect corporate financial and investment policies. Kydland and Zarazaga (2016) show that concerns about higher taxes caused by fiscal challenges depressed investment and slowed the recovery in the U.S. In this paper, we add insights into corporations' adjustment of their cash holdings and investment in response to macro-liquidity injections in terms of both the announcement and the excess inflow of liquidity to their lenders

\footnotetext{
${ }^{4}$ There is a large body of literature on corporate cash holdings that is too broad to be surveyed here. Azar, Kagy, and Schmalz (2016) argue that the lower cost of carrying cash can potentially explain the higher cash holdings in recent times. Our study extends this literature by examining the impact of unconventional monetary interventions, during which, at least for certain corporations with access to cheaper bank credit, the cost of holding cash is low.
} 
through an increase in (cheaper) external funding from the central banks. In the following sections, we will empirically examine the impact of macro-liquidity injections on corporate policies in the context of the ECB's LTRO liquidity injections.

\section{Data and Methodology}

\subsection{Data}

We collect data from several databases that contain European data so that we can analyze the impact of the ECBs liquidity interventions. These data are for the period ranging from the 2002 adoption of the Euro to 2014, thereby allowing us to look at differences in corporate liquidity, financial, and investment policies during both normal and distressed periods, along with periods characterized by ECB interventions. ${ }^{5}$

We use data on corporate fundamentals from the Compustat Global database. ${ }^{6}$ From this source, we identify a sample of European corporations and collect all yearly and quarterly corporate financial and stock price data for the period from 2002 to 2014. Because financial and utility corporations often have capital structures that are quite different from the average corporation, we follow the literature and exclude financial corporations (SIC codes 6000 to 6999), utility corporations (SIC codes 4900 to 4999) and corporations for which no SIC code is available. Furthermore, because we are interested in only active corporations, we follow Bates, Kahle, and Stulz (2009) and require corporations to have both a non-negative asset value and non-negative sales to be included in a given year (quarter). We supplement the data from Compustat with corporate data from the Capital IQ database. In contrast to Compustat, Capital IQ compiles, inter alia, detailed information on corporate debt structure, using financial footnotes contained in corporations' financial reports. Finally, we use CreditPro ${ }^{\circledR}$ (S\&P Capital IQ) rating data as a proxy for corporate credit risk so that we can estimate the impact of the ECBs extraordinary liquidity injection, after controlling for such risk. ${ }^{7}$

\footnotetext{
${ }^{5}$ We restrict our sample to the period after 2002 to ensure an alignment with the establishment of the Eurozone, whereas the end of our sample in the year 2014 is set in accordance with the availability of fundamental corporate data at the time of the data collection for this study.

${ }^{6}$ The advantage of using data from Compustat rather than, for instance, Amadeus (which is used in related European corporate studies), is that we have quarterly rather than annual data, which increases our sample size and allows for greater granularity in our analysis.

${ }^{7}$ To mitigate the effect of outliers, we winsorize the observations for our variables at the $1^{\text {st }}$ and $99^{\text {th }}$ percentiles. Furthermore, we follow the conventional approach in related empirical research (e.g., Bates, Kahle, and Stulz (2009))
} 
In addition to firm controls for corporate policies, we also use the five-year sovereign CDS spreads from Markit as a proxy for country credit risk. The five-year tenors are by far the most liquid CDS contracts, and they are the benchmark widely employed both in industry and in the related literature. We use end-of-quarter observations of the daily five-year CDS spread to match the quarterly corporate fundamental data. For additional country-specific measures, we use data from the World Bank. As a proxy for a country's overall exposure to other countries' economic conditions, we use data on the country's exports of goods and services. We also use these and other countryand industry-specific data, e.g., indicators of competition, to investigate the impact of differences in credit supply, along with demand differences, on sensitivity to the LTRO intervention across corporations. To measure the sensitivity of the effectiveness of ECB liquidity interventions in light of country-specific LTRO repayment and fiscal policies, we also collect both yearly data on national total LTRO holdings and quarterly data on each country's corporate tax rates and government investment expenditures over time. The data are obtained from the National Central Bank (NCB) reports from members of the Eurosystem and the ECB Statistical Warehouse. Appendix Table A3 provides a full description of all the variables used in our analysis.

We restrict our main sample to corporations located in the Eurozone to analyze the impact of liquidity interventions made by the ECB. This sample includes all corporations located in countries that belong to the European monetary union (i.e., the Eurozone) and that thereby were directly affected by the ECB's liquidity interventions. To exclude any potential biases or country-specific reasons for the later adoption of the Euro by some countries, we include only corporations from those countries that adopted the Euro as a common currency in 1999 and joined the European Monetary System from the time of its inception in January 2001. However, we collect similar data for both Eurozone and non-Eurozone corporations and use the latter as a control group for some of our subsequent analysis. ${ }^{8}$

Our main objective in this research project is to investigate the impact of liquidity intervention on corporate policies. To address this issue, we use the ECB's implementation of its unconventional and assume that a corporation has no R\&D expenditure in a given quarter if it is reported as "missing" by Compustat. We use the same argument for observations of corporations' merger and acquisition (M\&A) activities.

${ }^{8}$ Today, the Eurozone comprises 19 of the 28 European Union member states. Slovenia adopted the Euro in 2007 , Cyprus and Malta in 2008, Slovakia in 2009, Estonia in 2011, and, Latvia and Lithuania in 2015. Poland and the Czech Republic are current applicants. Because of missing CDS data for Luxembourg, we exclude corporations from that country (46 companies). The non-Eurozone sample includes corporations located within the EU but outside the Eurozone. For details, please see Appendix Table A1. 
three-year LTROs, which were set in place not only to increase the ECB's support for the Eurozone banking sector but also to improve the real economy. The two LTROs were unconventional in the sense that the ECB was, for the first time, offering refinancing operations with a maturity of three years. ${ }^{9}$ These operations were announced in early December 2011 and were implemented on December 21, 2011 (LTRO I) and February 29, 2012 (LTRO II). In general, as indicated by the steep increase in the amount of outstanding LTRO as presented in Appendix Table A1, the interventions overall turned out to be of significant size. For more detailed information about the ECBs unconventional liquidity interventions and the banks' uptake of liquidity provided by the three-year LTROs, we use data from two sources, both at the country and at the bank levels. Because we are particularly interested in whether and how much of the ECBs liquidity injection flowed to individual banks, we use country-specific aggregate information on the Eurozone banks' uptake of LTRO I and LTRO II. We also use bank-level uptake information hand collected from Bloomberg. ${ }^{10}$

Table 1 provides these LTRO uptake numbers within the Eurozone, sorted by country. ${ }^{11}$ As shown in the table, banks from the periphery countries were highly active because of their actual capital needs, as the LTRO was their only option for accessing medium-term funding. However, for many banks, participating in the unconventional LTROs also provided an opportunity to replace their shorter-term borrowing with low-cost three-year borrowing (FitchRatings (2012)). Therefore, banks in even highly rated and safe Eurozone countries such as Germany and France participated in the three-year LTRO. In addition, as Table 1 indicates, the participation in and uptake from the two LTROs were quite similar (both at the aggregate and country levels). The aggregate uptake was approximately 918 billion Euros, with Italian and Spanish banks being by far the most active in participation in terms of both the number of participating banks and the amounts borrowed. Together, banks in these two countries had an uptake of approximately $68 \%$ of the aggregate uptake (see, e.g., Appendix Figure A2). In terms of the significance of the ECB liquidity intervention, we can see from the ratio of the total LTRO uptake to central government debt that the liquidity

\footnotetext{
${ }^{9}$ Figure 1 provides a detailed timeline of the ECBs recent unconventional monetary policies. Appendix A provides background on the ECB open market operations.

${ }^{10}$ The data include bank-level uptake information related to LTRO I and LTRO II. We thank Matteo Crosignani for kindly sharing these data.

${ }^{11}$ Although the ECB liquidity injection was available only to banks located in the Eurozone, approximately $5 \%$ of the total uptake involved a few non-Eurozone banks that participated through their subsidiaries situated in the Eurozone.
} 
injection was greatest for countries in the Eurozone periphery, i.e., Greece, Ireland, Italy, Portugal, and Spain (GIIPS). We supplement these intervention-specific data with other Eurozone-wide data provided by the ECB. The latter are obtained from the ECB Statistical Data Warehouse, where all published reports and historical data are stored on a monthly or weekly basis, depending on the source. $^{12}$

\subsection{Empirical Specification}

In terms of methodology, our approach is twofold. In the first part of the paper, we investigate the impact of the ECB's unconventional LTROs on corporate policies, including liquidity, financing and investment policies. Our main measure of corporate liquidity is cash holdings, Cash. Cash is the most liquid asset a corporation can hold, and a change in cash holdings clearly reflects a change in corporate liquidity. Following Bates, Kahle, and Stulz (2009) and Subrahmanyam, Tang, and Wang (2017), we measure corporate cash holdings by the ratio of cash and cash equivalents to total assets. As outlined in Table 2, the cross-country average of corporate cash holdings is $8.29 \%$ for Eurozone companies. In line with Chen, Dou, Rhee, Truong, and Veeraraghavan (2015), we find wide variation in the cash holdings ratio across countries. Corporations in some countries, e.g., Portugal, have cash holdings that are less than half (4.0\%) those of the Eurozone in general, whereas those in countries such as Germany, France, and Ireland have cash holding ratios of above $10 \%$.

We relate corporate cash holdings to a set of explanatory variables and other controls, including both firm- and time-fixed effects. Our choice of the determinants of cash holdings in the empirical specification is motivated by the transaction and precautionary explanations for cash holdings. Market-to-Book is the book value of assets minus the book value of equity plus the market value of equity, all divided by the book value of assets. The Size variable is the logarithm of total assets. Leverage is measured as the book value of the long-term debt plus debt in current liabilities, divided by total assets. The variable Cash Flow is the ratio of cash flow to total assets, where cash flow is defined as the earnings after interest and related expenses, income taxes, and dividends. The variable Industry Sigma is the industry cash flow risk, measured by the mean cash flow volatility

\footnotetext{
${ }^{12}$ See, e.g., https://sdw.ecb.europa.eu/home.do, and http://www.ecb.europa.eu/stats/monetary/res/html/ index.en.html. Note that the ECB itself does not provide country- or bank-specific data regarding its intervention programs.
} 
across two-digit SIC codes. Net Working Capital is measured as net working capital minus cash, divided by total assets. $R \mathscr{E} D /$ Sales is the ratio of $\mathrm{R} \& \mathrm{D}$ to sales. Capital Expenditure is the ratio of capital expenditure to total assets. The variable Acquisition Activity is the corporation's costs related to acquisitions, scaled by total assets. Finally, the variable Rated is a dummy variable that is equal to one if the corporation is rated and zero otherwise.

In our investigation of the impact of the unconventional LTROs on the real economy (i.e., corporations investment and employment policies), we follow the literature and use the ratio of capital expenditure to total assets as the proxy for investment. Following Table 2, the average corporation in our sample uses $3.12 \%$ of its total assets on capital expenditure each quarter. As a proxy for employment compensation, we use Wages, which represents the corporations' total salaries and wages, given in logarithms. Our main controls in the investment and employment compensation model specifications are Cash Flow, Market-to-Book, Size, Leverage and Rated. Because investment and employment may also be determined by the lagged ratios of alternative investment measures, e.g., $R \& D$ and acquisitions, along with profitability and the degree of competition in the respective industry, we also use these controls in extended specifications. ${ }^{13}$ Our proxy for profitability, Sales, is the operating income (before depreciation) and is scaled by total assets. Our measure of industry competition is the Herfindahl-Hirschman Index (HHI), which is given by the sum of the squared market shares of corporations within the same industry for a given year.

Because this paper is based upon Eurozone corporations and provides a cross-country study, we also include sovereign CDS spreads, Sovereign CDS, and countries' ratios of exports to GDP, Sovereign Export, in our model specifications to control for sovereign credit risk and diversification of the economy across markets. As outlined in Table 2, the median CDS spread over the sample period within the Eurozone is approximately 17.62 bps. The sovereign CDS spread variable shows a large degree of cross-country and time-series variation, which implies that this is an interesting proxy for our study of unconventional monetary policies within the Eurozone. Likewise, we find a large variation in the countries' dependence on exports, which gives us the ability to study the impact of liquidity intervention for corporations that are (or are not) located in countries that rely heavily on local markets. ${ }^{14}$

\footnotetext{
${ }^{13}$ For alternative specifications of investment and employment models, see, e.g., Almeida and Campello (2007), and Duchin, Ozbas, and Sensoy (2010).

${ }^{14}$ Appendix Table A2 provides summary statistics for the non-Eurozone sample. Except for the significantly lower
} 
To capture the liquidity injection impact of the three-year LTROs, we use LTRO-Country Uptake as our main measure. LTRO-Country Uptake measures the differences between countries in terms of participation in the three-year LTROs and therefore, reflects the country-specific uptake of liquidity. In particular, LTRO-Country Uptake is equal to zero until the first round of the unconventional LTROs, Q4-2011, and equals the amount of each country's total uptake through LTRO I and II, scaled by the country's central government debt holdings in the year 2011, i.e.,

$$
\text { LTRO-Country Uptake }_{t, c}=\frac{\text { Total Country LTRO Uptake }}{t, c}
$$

where $t$ indicates the year-quarter and $c$ refers to the country. The interpretation of the variable is as follows: A high value of LTRO-Country Uptake implies that the uptake through the unconventional LTROs compared to existing government debt was significant and therefore, all else being equal, would have affected the local banking sector more than another country's banking sector that had a low uptake. Thus, this variable measures the country-specific significance of the unconventional monetary policy implemented by the ECB. The advantage of this specification is that the variable not only differentiates between countries that had a high or low uptake, respectively, but also considers whether the liquidity intervention was significant in relation to each country's local banking sector. Accordingly, we expect corporations located in countries that received relatively high liquidity injections to have been more heavily affected and to show a stronger reaction in terms of their liquidity management, financing, and investment policies. ${ }^{15}$

In section 4, we analyze the standalone impact of the LTRO-Country Uptake measure on corporate cash holdings, investments and employment compensation. We also investigate the impact of the LTRO intervention on corporate debt financing, which helps us determine the source of the change in corporate policy and therefore, the actual transmission of liquidity provided by the ECB to the corporate sector. In section 5, we further investigate the granularity of LTRO impact on investment. To this end, we study corporate policies in different subsamples. We start from corporations' reliance on bank debt and their bank-specific LTRO uptake (LTRO-Bank Uptake). We sovereign CDS spreads, we find no general differences between Eurozone and non-Eurozone corporations.

${ }^{15}$ In a robustness test, we use the ratio of country-specific LTRO uptake to the countries' GDPs as a proxy for the size of each country's economy. Our main results are robust to this alternative specification. As an alternative and simplified measure, we further use Post-LTRO, which is a dummy variable equal to one for year-quarter observations after the implementation of the first three-year LTRO intervention (Q4-2011) and zero otherwise. 
further investigate the role of banks' overall policies on repayments of the LTRO and (local) fiscal policies. To investigate the role of early repayment, we rely on end-of-year country-level LTRO data reported by the NCBs and use the percentage changes in country LTRO holdings between 2012 and 2013 to proxy for early repayments of the three-year LTROs across countries. To determine the role of variation in fiscal policies, we use corporate tax rates and government investment expenditures. These measures are based upon quarterly data provided by the ECB Statistical Warehouse. For the impact of corporate tax rates, we use Corporate Tax, which is the quarterly corporate tax rate given in percentages. ${ }^{16}$ However, because corporate tax rates vary over time only to a limited extent, we use end-of-year observations and specifically, country-specific year-to-year changes. As a measure of government spending, we mainly use Government Investment, which captures the ratio of government investment expenditures to GDP. To account for seasonality, in line with government budgeting within a financial year, we take the median of quarterly government investment expenditures to GDP ratio within a year. Based on this measure, we determine the yearly changes in government investment expenditures.

\section{LTRO and Corporate Policies}

In this section, we investigate the impact of the unconventional liquidity intervention on corporate policies. We focus on the effect of the three-year LTROs implemented by the ECB (macro-liquidity) and corporate liquidity management in terms of the precautionary demand for cash holdings (microliquidity). We also investigate the LTROs' impact on corporations' debt-financing policies, as a channel for changes in their cash holdings, and the consequent effect on corporate investment and employment compensation.

\subsection{Cash Holdings}

Macro-liquidity injections such as the ECB's unconventional LTROs do not always translate (directly) into corporate liquidity. An analysis of both the supply side (in this case provided by the banking sector) and the demand side (i.e., the corporate response) is necessary to understand such

\footnotetext{
${ }^{16}$ Corporate tax rates are measured as total tax rates and measure the amounts of taxes and other mandatory contributions payable by businesses, after accounting for allowable deductions and exemptions, as a share of commercial profits.
} 
liquidity transmissions. On the one hand, unconventional liquidity interventions may boost bank liquidity, making it less necessary for corporations to hold precautionary cash. If this were the outcome of the liquidity injection, that injection would have, from a corporate liquidity perspective, achieved the ECB's goal in undertaking the intervention. On the other hand, banks may use LOLR funding to take on additional sovereign risk rather than lend to corporations. Further, risk taking by banks may accentuate corporations' precautionary motives for holding cash. As a result, corporations may save more cash from their operating cash flows or even borrow more and save the proceeds as additional cash holdings (cash hoarding). If the latter effect dominates, we would expect to see corporations in the Eurozone, particularly those situated in countries with a high LTRO uptake, increase their precautionary cash holdings following the LTRO intervention.

Whether a boost in bank liquidity (and therefore, the transmission of liquidity to the corporate sector) would be effective depends not only on the supply side but also on the demand for and cost of corporations' products and services. At the onset of the European sovereign debt crisis, aggregate demand was clearly down; indeed, when the unconventional LTROs were introduced in late 2011, demand across European countries and markets remained slack. Thus, in this framework of high demand uncertainty, corporations would have been likely to maintain their precautionary motives for holding significant amounts of cash. Consequently, and independent of the supplyside effect, it is very unlikely that a liquidity injection into the banking sector would have led to decreases in corporate cash holdings. Thus, if corporate demand uncertainty remained large, and accordingly impaired the lending-supply shock effect, we would expect that corporations in the Eurozone, particularly those based in countries with a high LTRO uptake, would have increased their precautionary cash holdings following the LTRO intervention.

To investigate the impact on the corporate cash holdings response to the LTRO intervention, we first note the determinants of cash holdings used in the model proposed by Opler, Pinkowitz, Stulz, and Williamson (1999) and Bates, Kahle, and Stulz (2009). In addition to the conventional determinants of corporate cash holdings, we include the variable LTRO-Country Uptake as our main variable of interest. We conduct the analysis in our sample of Eurozone corporations, and the results are presented in Table 3, Model 1. As seen in Model 1, we find a positive and significant coefficient estimate for LTRO-Country Uptake at the 1\% level, suggesting that Eurozone corporate cash holdings increased following the unconventional LTROs liquidity injections. More specifically, we 
find that this effect increases with LTRO-Country Uptake, which means that corporations located in countries in which the excess inflow of liquidity to lenders was high, on average, increased their cash holdings by approximately $0.55 \%$, compared to that of other corporations. ${ }^{17}$ The coefficients for the other control variables are generally consistent with prior findings. Corporations with high Market-to-Book and $R \mathscr{E} D /$ Sales ratios have greater precautionary cash holdings, since it is costlier for them to be financially constrained. Large corporations generally have less cash due to the economies of scale in holding cash. Capital Expenditure and Acquisition Activity, which create assets that can be used as collateral for borrowing, lead to a decrease in precautionary cash holdings. With regard to our specified country controls, Sovereign CDS and Sovereign Export, we find that countries with higher credit risk and lower export intensity hold more cash in general, which is in line with the precautionary motive for holding cash.

The three-year LTROs implemented by the ECB provided a significant liquidity injection to banks in the Eurozone. Such a macro-liquidity injection may have generated a positive bank lending shock, and thus, not only have created an immediate source of additional borrowing for corporations but also have mitigated corporations' uncertainty about the future credit supply. With a positive bank lending shock, corporate cash holdings and the capital expenditures of corporations that are reliant on bank borrowing will fall and rise, respectively. Therefore, we expect corporations that pre-intervention relied to a large extent on bank debt, and thus, had access to bank debt as an external financing source, would have been more strongly affected by the macro-liquidity injection, all else being equal. However, if macro-liquidity injections cannot mitigate corporate uncertainty about the future (bank) lending supply, we would expect to observe a greater increase in cash holdings and an even larger decrease in investment for bank-reliant corporations.

Based upon the above argument, we use corporations' reliance on bank debt to initially test the impact of the LTRO intervention on cash holdings. More specifically, we separate corporations into subsamples with High Bank Debt and Low Bank Debt. The separation is based upon the corporations' bank debt obligations (Bank Debt) one year before the first three-year LTRO intervention (Q4-2010). Bank Debt is the corporations' debt in the form of bank loans divided by total assets. Then, the High Bank Debt (Low Bank Debt) subsample includes corporations with a bank debt

\footnotetext{
${ }^{17}$ The country-specific LTRO uptake typically differs by $25 \%$, implying that for such a change, the difference in corporations' cash holdings is $25 \% * 2.2=0.55 \%$. For the average corporation, this means that cash holdings increase from $8.3 \%$ to $8.9 \%$.
} 
to asset ratio above (below) the median. In Table 3, Models 2 and 3, we present our results for corporate cash holdings.

As shown in Table 3, Model 2, we find a positive and significant coefficient for corporations that use bank-related loans and credits as their main source of debt financing. In contrast, and as outlined by Table 3, Model 3, the coefficient is positive, but insignificant, for less bank-reliant corporations. Therefore, the results suggest that corporations that used bank loans as their main source of debt financing prior to the three-year LTRO interventions, and accordingly were more closely related to their banks, increased their cash holdings more than corporations with no (or only minor) use of bank debt did. Thus, although all corporations may have had a heightened precautionary motive for holding cash, only those with a (significant) amount of bank borrowing actually increased their liquidity, i.e., their cash holdings. This finding may underscore the fact that at least one source of our finding of increased cash holdings is the increase in existing bank borrowing that followed the LTRO intervention and the subsequent bank lending shock. In particular, corporations may have been able either to refinance existing loans (debt renegotiation, including improved borrowing conditions) or to take out new loans. ${ }^{18}$ In both cases, corporations may have been able to hoard the additional proceeds from bank borrowing as cash. ${ }^{19}$

Overall, the results suggest that corporations in the Eurozone increased their cash holdings following the LTRO liquidity injection. However, the impact of a macro-liquidity injection on corporate liquidity policies may also depend on corporations' precautionary motives and the marginal value of cash. When the marginal value of cash is high, corporations have a greater precautionary demand for cash holdings. Therefore, we expect that such corporations would have been more likely to increase their cash holdings following the announcement of an unconventional liquidity injection. In unreported results, we use the corporations' credit rating and leverage ratios as proxies for credit risk, underscoring the precautionary demand for cash holdings, and show that the impact of unconventional LTROs on cash holdings is amplified for more risky corporations, i.e., those with a greater precautionary motivation for holding $\operatorname{cash}^{20}$

\footnotetext{
${ }^{18}$ For more information, see, e.g., FitchRatings (2012).

${ }^{19}$ In line with this argument and the fact that large corporations are in general less constrained and have better access to lending, one would expect large corporations to have exploited the bank lending supply shock that much more. In unreported results, we confirm this hypothesis when classifying our sample into large and small corporations and show that the increase in cash holdings following the LTRO is more pronounced for large corporations.

${ }^{20}$ Note that corporations with higher credit risk are in general also more constrained financially, e.g., they have more limited access to debt markets and thus must borrow at a higher cost, which may lead not only to greater cash
} 


\subsection{Debt Financing}

To investigate whether the LTRO intervention may indeed have increased corporations' cash holdings because of an increase in corporate borrowing, we next analyze the impact of the unconventional LTROs on corporate debt-financing policies. For this investigation, we use several corporate debt-financing measures, and the results for all alternative specifications are presented in Table 4. As before, the variable of interest is LTRO-Country Uptake, and as indicated in Table 4, Model 1, we find positive and significant coefficients for corporate Leverage. In addition, we find a positive and significant coefficient for LTRO-Country Uptake in the model for Net Debt, Model 2, which is defined as the ratio of current plus non-current liabilities minus cash holdings to total assets. These results suggest that the increase in corporate leverage is even larger than the increase in cash holdings, suggesting that cash is not equivalent to negative debt. For Short-term Debt (Model 3), which includes all current liabilities of the corporations, we find a negative impact. This finding suggests that corporations may have replaced shorter-term liabilities with longer-term liabilities. Recall that the LTRO intervention was an unconventional monetary policy that for the first time provided three-year funding opportunities for Eurozone banks. The participating banks' replacement of their own short-term borrowing with longer-term borrowing not only have increased bank lending to the corporate sector in general but also may have caused banks to offer loans with longer maturities to the corporate sector. A related discussion in the case of French corporations can be found in Andrade, Cahn, Fraisse, and Mésonnier (2015).

In line with the findings by Darracq-Paries and Santis (2015), we conclude from our results that corporations increased their reliance on debt financing following the macro-liquidity injection. More specifically, our results show that the three-year LTROs significantly increased the chances of loans being provided to non-financial corporations and that corporations, on average, were able to increase their leverage ratio by approximately $1.1 \%{ }^{21}$ This supports the view that the three-year LTROs can be interpreted as a favorable credit supply shock. Thus, the bank liquidity shock may indeed have been transformed into a bank lending shock through which Eurozone corporations

holdings (Azar, Kagy, and Schmalz (2016)) but also to an increased precautionary demand for cash holdings (Bolton, Chen, and Wang (2014)).

${ }^{21}$ The country-specific LTRO uptake typically differs by $25 \%$, implying that for such a difference, the leverage is $25 \% * 4.4=1.1$ percentage points higher for corporations in LTRO uptake countries, which implies a change in the leverage ratio from $22 \%$ to $23.1 \%$ for the average corporation. 
were able to increase their debt financing. Given the results showing both increased corporate cash holdings, particularly, for corporations that are highly reliant on bank debt, and increased leverage, we can infer that increased borrowing may have been an important source of the increase

in cash holdings. However, we emphasize that based only on this analysis, we cannot exclude the possibility that there may have been other sources of funding for that increase.

\subsection{Investment and Employment Compensation}

The implementation of the liquidity intervention by the ECB may not only have affected corporate liquidity management but also may have had an impact on corporate investment and employment decisions. Corporate access to debt markets has an impact on investment (Harford and Uysal (2014)), and financing frictions do affect corporate investment decisions (Almeida and Campello (2007)). Thus, the availability of debt financing, and therefore, the credit supply shock, may have affected corporations' investment policies, such as capital expenditures. Likewise, we expect that the increased availability of debt financing may have increased employment compensation. In particular, the impact on employment compensation could be attributable to either an increase in the level of wages or an increase in the number of employees. Both a positive effect on investment and increased employment compensation would suggest that the LTRO intervention had an ameliorating impact on the real economy. However, as with corporate cash holdings, corporations' investment and employment compensation decisions both depend upon economic uncertainty and in particular, the uncertainty of product demand (Guiso and Parigie (1999)). If product demand is low, then corporations would be more reluctant to invest, for instance, in property, plants, equipment, and employees. In this framework, the LTRO intervention and the related increase in corporations' debt financing may not have led to increased investment. Because demand uncertainty at the time of the LTRO implementation was clearly high, it would have been optimistic to have expected a positive impact on either corporate investment or employee compensation: in other words, we would not expect that the intervention alone would have been able to resolve the problem of demand uncertainty. In terms of the ECB's intended objective of introducing the LTRO intervention, this would mean that the unconventional LTROs may not have boosted the real economy and thus not have achieved the ECB's goal, at least at the corporate level.

To investigate whether the LTRO intervention had an impact on corporate investment and 
employment decisions, we next present the results of our investigation of proxies for corporate investment and employment compensation. The analysis is conducted among the sample of all corporations in the Eurozone, and the results are presented in Table 5. The variable of interest is LTRO-Country Uptake. In Models 1 and 2, we use the ratio of capital expenditure to total assets as our proxy for corporate investment. In Model 1, we add only controls that affect the corporate capital expenditure decision. In Model 2, we add lagged versions of alternative investment measures such as dividend payment, R\&D investment, and acquisition activities, along with other controls, as a robustness check. As the table shows, after controlling for corporate fundamentals, we find a negative and significant coefficient for the country-specific LTRO uptake measure, which indicates that corporations located in countries with a high uptake of additional liquidity in the banking sector actually reduced investment following the LTRO intervention; on average, they decreased investment by $0.43 \%$ following the LTRO intervention. ${ }^{22}$ One explanation for this finding is that the LTRO implementation came with additional baggage in terms of banks use of the increased liquidity for purposes other than corporate lending, such as investment in high-yield sovereign bonds. This usage may have increased uncertainty about future product demand and therefore, corporations may have become more reluctant to invest. This argument is in line with our previous finding of increased precautionary cash holdings.

In Table 5, Models 3 and 4, we provide the same analysis for corporate employment compensation. As a proxy for employment compensation, we use corporations' total expenses related to wages (on a logarithmic scale). In this case, we do not find a significant effect for the LTRO uptake measure. Therefore, similar to the case of corporate investment, corporate spending on employees was not positively affected by the introduction of the unconventional LTROs. Our tentative conclusion is that although corporations may have had access to more debt financing, they did not use the proceeds from the additional borrowing to invest in their businesses but instead hoarded them as cash.

To better understand the investment reduction following the LTRO intervention, we investigate the impact of general economic uncertainty at the time of the intervention on the corporate

\footnotetext{
${ }^{22}$ The country-specific LTRO uptake typically differs by $25 \%$, implying that for such a difference, the investment difference is $25 \% * 1.70=0.43 \%$. Given the $1.1 \%$ increase in leverage, the $0.55 \%$ increase in cash holdings, and the $0.42 \%$ decrease in investment following the LTRO intervention, corporations may have used the additional debt for precautionary cash holdings and other purposes, rather than increased investment.
} 
response to the liquidity injections. Considering the recent crisis in Europe, economic uncertainty was generally higher for Eurozone corporations that faced greater industry competition, that relied more heavily on domestic demand, and that were situated in the periphery, i.e., in high-risk countries. Accordingly, the corporate response and reception of the LTRO intervention might have been different for corporations facing different levels of economic uncertainty, e.g., product-demand uncertainty (Kahle and Stulz (2013)). ${ }^{23}$ If the liquidity injection did not help resolve the productdemand/cost uncertainties following the European Sovereign debt crisis, corporations with greater uncertainty before the intervention may have had an even greater precautionary demand to hold cash afterwards and may have become even more reluctant to make new investments. To investigate the role of demand uncertainty, we analyze corporations' reliance on the domestic market. In particular, we investigate the impact of demand uncertainty by separating our sample of Eurozone corporations into those located in high- and low-export countries, respectively. As presented in Appendix Table A4, Models 1 and 2, we find that corporations situated in countries with a greater reliance on domestic markets (low export), in contrast to those in high-export-oriented economies, significantly decreased their investment following the LTRO liquidity injections. Since the objective of the LTRO liquidity injections was to stimulate the real economy in the Eurozone, the greater decrease in investment for corporations with a high dependence on the domestic market suggests that the interventions' effectiveness was challenged by the significant demand uncertainty that Eurozone corporations faced at the time of its implementation. ${ }^{24}$

Just as corporations' export reliance determines demand uncertainty, industry competition may also affect the corporate supply incentive, which plays a role in shaping corporate investment decisions (Valta (2012), Akdoğu and MacKay (2008)). In particular, corporations in highly competitive industries are typically more aggressive in increasing their investment and therefore, we would expect to observe (positive) effects of the LTRO liquidity injections on investment for corporations operating in more competitive industries. However, as shown by the results in the Appendix Table A4, Models 3 and 4, we find a decrease in investment across different levels of industry competition. ${ }^{25}$ Thus, in general, our results suggest that corporate supply incentives do not drive the

\footnotetext{
${ }^{23}$ Similarly, market expectations may also have affected corporate investment policies (Gennaioli, Ma, and Shleifer (2016)).

${ }^{24}$ In a similar test on corporate employment compensation, we find no significant change in employment compensation for either high- or low-export-oriented corporations.

${ }^{25}$ In unreported results, we further use industry capital intensity and corporate cash flows as proxies for corpora-
} 
finding of a decrease in investment following the liquidity injections but instead that the conclusion of lower investments following the LTRO intervention was attributable to larger concerns about the macro-economic environment, i.e., demand uncertainty.

\subsection{Counterfactual Analysis: Eurozone versus Non-Eurozone Countries}

The results from the previous sections suggest that the unconventional LTROs were ineffective in boosting corporate investment, since corporations have concerns other than the availability of macro-liquidity when making their investment decisions. In particular, corporations' concerns about the uncertainty of demand for their products seem to have impeded the positive impact of the LTRO intervention on the real economy. Moreover, our results suggest that corporations tended to hold more cash reserves after the LTRO liquidity injections. Although these findings help us develop a better understanding of the real effects of the LTRO intervention and may have implications for the design of future monetary policies, we do not propose that the ECBs LTRO intervention made things worse or that corporate investments would have been higher had the ECB not implemented the unconventional LTROs. To explicitly address this point, we use non-Eurozone corporations as the benchmark to compare corporate investments with and without the influence of the LTRO liquidity injections. Although using non-Eurozone corporations as the benchmark may be challenged based on other fundamental differences between Eurozone and non-Eurozone economies, the comparison can be considered a rough "counterfactual analysis" investigating the impact of the ECB's three-year LTROs.

We investigate corporate policies after the LTRO intervention occurred in a sample of corporations located in the EU, with non-Eurozone corporations used as the control group for the LTRO effects. Whereas banks in the Eurozone countries may have had access to LTRO liquidity injections during the two rounds of unconventional LTROs, non-Eurozone countries did not have such access. $^{26}$ To account for major differences in economic conditions across countries and the corresponding deferred impact, we match the EU sample countries based upon their sovereign risk when

tions' financial constraints, which may harm corporate supply incentives. We find that corporations' reduction in investment following the LTRO intervention is independent of whether they are financially constrained.

${ }^{26}$ This is valid with the exception of non-Eurozone banks with bank subsidiaries located in the Eurozone. Additionally, we do not account for other stimulus measures that may have been implemented in the non-Eurozone countries during the same period, which would be biased against our finding of a positive impact of the LTROs in the Eurozone countries relative to the non-Eurozone countries. 
investigating the impact of the unconventional LTROs. In particular, we measure country risk using the country's CDS spreads two years before the LTRO intervention. High (Low) Sovereign Risk is defined as a CDS spread above (below) the median in the pre-intervention and crisis period, i.e., in 2009 and 2010, respectively. In Appendix Figure A3, we first compare the market-to-book values of Eurozone and non-Eurozone corporations across years. The market-to-book ratio is a relative metric that measures the valuation of a corporation, with a market-to-book value greater than one indicating a highly valued corporation. We observe an increasing trend in the market-to-book ratios for both Eurozone and non-Eurozone corporations following the LTRO liquidity injections. Most interestingly, we see that although the difference between the market-to-book ratios of corporations from high- and low-risk Eurozone countries, respectively, widened following the financial crisis, the spread actually declined following the LTRO intervention period. The decrease in the spread in the market-to-book ratios was particularly driven by Eurozone corporations in countries with high sovereign credit risk, as these corporations exhibited a greater increase in this spread. In the meantime, the spread in the market-to-book ratios between the high- and low-risk groups of corporations outside the Eurozone increased even more following the intervention.

Next, we conduct a regression analysis within the sample of corporations located in the EU, using non-Eurozone corporations as our control group. The results for cash holdings, leverage, investment, and wages are presented in Table 6 Panels A, B, C, and D, respectively. In Model 1 of all the panels, we use the full sample of corporations. The variable Post-LTRO is a time dummy variable equal to one for year-quarter observations occurring after the ECB had implemented the first three-year LTRO intervention (Q4-2011) and indicates the timing of the LTRO intervention. The variable Non-Eurozone is a dummy equal to one for corporations located in countries that do not belong to the Eurozone. The variable of interest in this counterfactual analysis is Post-LTRO $\times$ Non-Eurozone, which is the interaction term between the LTRO intervention and non-Eurozone dummies. The variable is equal to one for non-Eurozone corporations in year-quarters following the first LTRO intervention and therefore captures the effect of the liquidity intervention on corporate policies in non-LTRO countries (the "counterfactual" effect). As seen from Model 1 in Table 6 with the term Post-LTRO $\times$ Non-Eurozone, non-Eurozone corporations had lower cash holdings and lower leverage ratios during the post-LTRO intervention period than corporations in the Eurozone. Moreover, we find a negative and significant coefficient for the term Post-LTRO $\times$ Non-Eurozone 
for both the investment and wages analyses. This finding suggests that non-Eurozone corporations may not only have had less access to a substantial financing source but also have experienced an even greater decrease in investment than corporations in the Eurozone.

In Models 2 and 3 of Table 6 Panels A, B, C, and D, we further separate our sample of corporations in the EU into high- and low-sovereign-risk subsamples based on the risk of the country in which a corporation is located. The separation is similar to that used in Figure A3. We then compare corporate policies during the post-LTRO intervention period for the high- and lowsovereign-risk groups. In the sample of corporations in low-risk countries, we find that Eurozone corporations had a greater increase in their cash holdings (and leverage) following the LTRO than non-Eurozone corporations (the "counterfactual"). Although the difference in corporate cash holdings is not significant for the high-risk group, we find that non-Eurozone corporations in high-risk sovereigns had significantly lower leverage ratios following the LTRO intervention. In general, this provides evidence of the presence and transmission of LTRO funds for Eurozone corporations. Furthermore, we find that Eurozone corporations in both the high- and low-risk groups experienced a greater decrease in their investment and wages following the unconventional LTROs than did non-Eurozone corporations. In Figure 2, we also plot the level of cash holdings and investment of Eurozone and non-Eurozone corporations, matched by sovereign risk, around the LTRO liquidity injections. Before the LTRO implementation, they generally showed similar trends in their cash holdings, leverage and investment, which validates the matching based on country risk. However, after the LTRO implementation, the Eurozone corporations exhibited a greater increase in their cash holdings and leverage. We also observe a slight decrease in investment for Eurozone corporations.

If one takes non-Eurozone corporations (or sovereign-risk-matched non-Eurozone corporations) as the "counterfactual" of Eurozone corporations that were exposed to LTRO liquidity injections, the results in this section suggest that although the unconventional LTROs were unable to boost corporate investment for Eurozone corporations, the economy might have fared even worse (with lower corporate liquidity, lower debt financing, lower investment, and lower employee payments) without the LTRO intervention. Said in other words, these results suggest that the LTROs helped Eurozone corporations sustain their investments better than corporations elsewhere in Europe at the onset of the European Sovereign Debt Crisis. 


\section{The Granularity of LTRO Impact on Investment}

Our previous evidence suggests that the unconventional ECB liquidity injections were not sufficient to boost corporate investments, but as a lower bound, they may have halted the deterioration of investment cuts. However, for a strong recovery of the real economy following monetary policy implementations, we expect to see increased corporate investment. In this section, we further investigate asymmetries in the impact of the LTRO, particularly the setting in which the two LTROs could stimulate corporate investment. Corporations may have different reactions to the liquidity injection because of corporation-specific, bank-specific, or local country characteristics, which may further affect the signaling and transmission effects of the LTROs. We start from corporate bank debt reliance and bank-specific LTRO uptakes of corporations. Considering that the LTRO injections operated through the banking system, the liquidity transmission and investmentboosting effect should have been more prominent for these corporations. We then investigate whether the effect of the LTRO intervention varies across banks repayment choices. Finally, we explore the role of the interaction between (local) fiscal and monetary policy in boosting real investment.

\subsection{The Impact of Bank Debt Reliance}

The three-year LTROs implemented by the ECB provided a significant liquidity injection to banks in the Eurozone. The stated objective of the program was that with a positive bank lending shock, corporate investment might increase because of a loosening of financial constraints and the actual provision of additional financing. In particular, the ECB hoped that investment might increase through corporations' usage of bank financing and specifically, would help those corporations that might not have had access to alternative sources of funding. In that sense, corporations' reliance on bank debt would be an important measure of the effectiveness of the transmission. However, if the macro-liquidity injections did not mitigate corporate uncertainty about the future, we would expect to observe no change or even a decrease in investment for all corporations, despite access to additional financing. To add evidence to our investigation of the unconventional LTROs' impact

on the real economy to this end, we provide an analysis of corporate investment, conditional on corporate dependence on bank debt. 
Specifically, in Table 7, we separate corporations into the subsamples High Bank Debt and Low Bank Debt based upon their bank debt obligations (Bank Debt) one year before the first three-year LTRO intervention (Q4-2010). Next, we run the same subsample analysis for corporate investment and employment compensation policies as for corporate cash holdings. For our measure of investment, Capital Expenditure, we find negative and significant coefficients for the LTRO uptake measure in both specifications, i.e., Models 1 and 2. Because the coefficients are quite similar in magnitude for high- and low-bank-reliant corporations, the results suggest that there is no significant difference between the two subsamples. Likewise, we present in Table 7, Models 3 and 4, our results for our measure of employment compensation, Wages, conditional on bank debt dependence. In contrast to our investigation of cash holdings and investment, we do not find any significant effect when we investigate the bank-reliance impact on employment compensation following the LTRO intervention. Thus, although we condition our model on corporations' reliance on bank debt, we (again) do not find evidence of a positive impact of the liquidity interventions on corporate employment compensation. These results may be partially driven by the stickiness of corporate employment and compensation policies in general.

Overall, the investment results conditional on bank debt dependence presented in this section provide additional evidence that the LTRO intervention did not boost the real economy, at least in the medium term. If bank debt reliance is a good proxy for corporations access to the bank credit supply channel, the results suggest that the corporations did not change or even decrease investment, and not because of their lack of access to the positive bank credit supply shock following the LTRO intervention. There might have been other factors that affected the LTRO effectiveness, leading to asymmetries in the LTRO transmission.

\subsection{The LTRO Transmission from Banks to Corporations}

To further understand the transmission channel, we utilize detailed bank-firm relationship data (from LPC Dealscan) and bank-level LTRO uptake data (from the ECB) to measure the liquidity injection effects at the corporate level. Although our main focus in the paper is to examine the aggregate impact of the LTRO intervention on corporate policies, it should be stressed that the effectiveness of the liquidity transmission to the corporate sector largely depends on the response of and the changes in the lending behavior of banks that participated in the three-year LTROs. In 
other words, corporations with a relationship to such an "LTRO bank" should, all else being equal, be more affected by the ECB's LTRO intervention, if it indeed had a significant impact. On the one hand, a corporation's relationship to an LTRO bank establishes a direct link to the injected macro-liquidity. On the other hand, these corporations would also be more exposed to additional risk taking by the LTRO banks.

To provide a deeper investigation of the impact of the LTRO-bank relation, we collect syndicated loan information from the LPC Dealscan database and create a subsample of corporations with lender and loan information. In particular, we match the information on banks that participated in the LTROs with the lender-share and loan-facility data in LPC DealScan. Simultaneously, we match our main sample of Eurozone corporations with the loan-facility data in LPC Dealscan. ${ }^{27}$ Then, by using the loan-facility data, we match the LTRO-participating banks (as lenders) with a subsample of the Eurozone corporations (as borrowers) and in particular, identify whether those corporations have a relationship with a bank that participated in the unconventional LTROs. Using this procedure, we match 953 corporations, 476 of which have an LTRO-Bank relationship. Appendix Table A5 shows the corporation-specific summary statistics and confirms that there is no major sample bias induced by our procedure for identifying loan relationships. ${ }^{28}$

To explicitly study the impact of corporations' access to LTRO funds, we define a corporatespecific LTRO exposure measure, LTRO-Bank Uptake, based upon the hand-collected bank-level uptake from Bloomberg. Similar to the LTRO-Country Uptake measure, LTRO-Bank Uptake is equal to zero until the first round of the unconventional LTROs, Q4-2011. However, thereafter it equals the amount of the average LTRO uptake of related banks through LTRO I and LTRO II, scaled by the size of each related bank, i.e., total assets, as of 2011. The measure is determined as

$$
\text { LTRO-Bank Uptake }_{t, i}=\sum_{j=1}^{N_{i}}\left(\frac{\text { Bank LTRO Uptake }_{t, j}}{\text { Bank Size } 2011, j}\right) / N_{i}
$$

where $t$ indicates the year-quarter, $i$ refers to the corporation, $j$ refers to a related bank and $N_{i}$ refers to the total number of LTRO-bank relationships the corporation has. The interpretation of

\footnotetext{
${ }^{27}$ Based upon our data on bank-level uptake information for the Eurozone banks that participated in the LTROs, we identify 89 banks as lenders with syndicated loans covered in LPC Dealscan. We match Dealscan borrowers with Compustat corporations by using the Dealscan-Compustat Link provided by Chava and Roberts (2008) and by hand-matching corporations by name and country of origin.

${ }^{28}$ Because LPC Dealscan provides loan pricing information on syndicated loans, which are typically made to larger corporations, there is a minor sample bias in terms of corporate size.
} 
the variable is as follows: A high value of LTRO-Bank Uptake implies that the LTRO uptake of banks with which the corporation has an existing lending relationship compared to the size of the related banks on average was significant and therefore, all else being equal, makes it more likely that the corporation had access to (and obtained) additional funds stemming from the LTRO liquidity injections.

In Table 8, we provide an analysis of the impact of LTRO liquidity injections on corporate investment in the subsample of corporations for which we have lender information. Models 1 and 2 in Table 8 present the regression results for corporate investments and employment, respectively, where we add the corporate-specific LTRO-Bank Uptake measure. Our expectation is that corporations that had an existing borrowing relationship with banks that obtained a significant amount of the LTRO funds are in general more likely to be positively affected by the LTRO credit supply shock. However, rather than a positive impact, we find a negative and statistically significant coefficient for LTRO-Bank Uptake for investments, whereas the coefficient for LTRO-Bank Uptake is positive and statistically insignificant for wages. The results also suggest that corporations with relatively good access to the LTRO funds decreased investment in the aftermath of the LTRO intervention. In other words, the average corporation did not increase its investment, although in relative terms, it may have had direct access to the additional credit supply provided by the ECB.

\subsection{The Effect of Early Repayment of LTRO Funds}

As part of the ECBs unconventional monetary policies during the Eurozone crisis, the three-year LTROs were launched to forestall a curtailment of credit to the banking systems in the member countries and to ensure the smooth transmission of monetary policy to the real economy. To increase the attractiveness of the unconventional LTROs, participating banks were given the option to repay, either in part or in full, the amount of their borrowings after one year without any penalty. Under this arrangement, the first three-year LTRO (LTRO I) could be repaid after January 25, 2013, and the second (LTRO II) could be repaid after February 22, 2013. Because banks are closely monitored by financial market participants, it is likely that LTRO-participating banks would have chosen to repay the three-year LTROs money at the early opportunity, either to signal improvements in their individual funding conditions or because of their decreased funding needs during the process of 
balance sheet adjustment. ${ }^{29}$

However, this early-repayment option may have undermined the stimulative effect of the LTRO. When banks were able to repay a large amount of LTRO funding after one year, it was less likely that they would use the LTRO funds for corporate lending and accordingly and that the LTRO liquidity would be fully transmitted to corporate balance sheets. In this setting, we may observe no significant change in corporate leverage in the aftermath of the intervention. However, the LTRO intervention may still stimulate corporate investment because of the signaling effect. In particular, the initially widespread nature of the LTRO uptakes may have allayed the European banks funding concerns. In contrast, banks' subsequent early repayments may have further signaled improvements in their individual funding conditions. Therefore, LTRO intervention may have helped the real economy through both the real liquidity injection channel, i.e., an increase in both corporate borrowing and investment, and the signaling channel, i.e., an increase in corporate investment even when there is no change in corporate borrowing. The signaling channel may dominate when banks use the early-repayment option to signal improvements in their funding conditions.

To investigate the role of early repayment, we rely on end-of-year country-level LTRO data reported by the NCBs to proxy for country-specific LTRO early repayments by banks. Specifically, we use the percentage changes in the country-level LTRO holdings between 2012 and 2013 as a proxy for early repayments of the three-year LTROs across countries (for details, see Appendix Table A6). ${ }^{30}$ One interesting observation from this measure is that the bank repayments differ for non-GIIPS (core) and GIIPS (periphery) countries. In general, non-GIIPS countries had high LTRO repayment rates. At the extreme, German banks exhibited an $80 \%$ decrease in their reliance on LTRO money from the year 2012 to 2013. Other non-GIIPS countries in our sample (i.e., Austria, the Netherlands, Belgium, and France) also showed a sharp decrease of approximately $64 \%$ in their holdings of LTRO money during this period. Among GIIPS countries, there are mixed patterns in the LTRO early repayment, with more modest amounts in Portugal (13\%), Italy (20\%), and Greece (29\%), and larger repayments of approximately $45 \%$ in Spain and Ireland.

Based on our proxy for early LTRO repayments, we separate our sample of corporations into

\footnotetext{
${ }^{29}$ See ECB Monthly Bulletin, February 2013.

${ }^{30}$ The country-level LTRO data from the NCBs may contain LTROs with other maturities, such as three-month and one-year LTROs. However, most of the LTROs during 2012 and 2013 were of three-year maturity. As discussed in the 2013 annual report of the Bank of Spain, "Most of the decrease in this balance took place in January when institutions availed themselves of the early redemption option offered by three-year refinancing operations."
} 
three groups: Low Early LTRO Repayment (Portugal, Italy, and Greece), Medium Early LTRO Repayment (Spain, Ireland, Austria, the Netherlands, Belgium, France), and High Early LTRO Repayment (Germany). Next, we examine the impact of the LTRO intervention on corporate policies for the three different groups. Since we wish to explore the impact of the early repayment of LTRO funding, which occurred at the bank level, and determine for how long the LTRO funds may have been accessible to corporations through existing bank lending relationships, we conduct our analysis in the bank-firm linked sample, where the transmission of the repayment mechanism is more likely to be visible. Accordingly, we also investigate the LTRO impact by using the corporationspecific LTRO-Bank Uptake measure.

The results regarding the impact of early repayments for the effectiveness of the unconventional LTROs are presented in Table 9. As seen from the table, we find evidence that the impact of the LTRO intervention on corporate policies significantly differs across the early LTRO repayment groups. For corporations in countries with relatively low early repayments in 2013 (i.e., Portugal, Italy and Greece (Panel A)), we find a significant increase in corporate leverage after the LTRO liquidity injections for corporations with better access to the LTRO funds. However, there is no increase in leverage for corporations in countries with medium and high early repayment (Panels $\mathrm{C}$ and D). These findings are intuitive, since we expect a lower transmission of funds for high early repayers of LTRO funds, which is particularly observed for banks in the non-GIIPS countries. Moreover, we find that corporations increase their cash holdings when they are in a low early repayment country, which not only is consistent with the precautionary demand for cash holdings rather than investments for corporations in high-risk countries but also can be related to the additional financing made available by the two three-year LTROs providing a source for cash hoarding by these corporations. In addition, for corporations in countries with medium early repayment (Spain, Ireland, Austria, the Netherlands, Belgium, France), we observe not a positive but a negative impact on investment. However, the corporations in these countries show a decrease in their short-term holdings, which may have stimulated and led to the observed decrease in these corporations' precautionary demand for cash following the LTRO intervention. Furthermore, for corporations in the country with very high early repayment (i.e., Germany (Panel C)), we observe an impact neither on corporate liquidity nor on debt-financing policies. However, in contrast to all earlier findings, we find that on average, German corporations increased their investment after 
LTRO liquidity injections, despite having experienced no significant increase in leverage. These findings are consistent with the important role of the signaling effect of LTRO liquidity injections for Germany and may further outline that corporations in the safer Eurozone countries may have been relatively less affected by the economic downturn following the European Sovereign Debt Crisis.

In Appendix Table A7, we further investigate whether the impact of the bank-level LTRO uptake and early repayments differ for large and small corporations, i.e., corporations that are relatively less or more financially constrained. In general, small corporations rely more on bank debt financing and have fewer alternatives when their bank lenders are financially constrained. As a result, they may respond more positively to the LTRO intervention and its positive signals of bank funding conditions when the constraints are loosened. As seen in Panel A in Appendix Table A7, we find an increase in leverage and investment for both small and large corporations in countries with very low early LTRO repayment. However, although large corporations seem particularly likely to have used LTRO funds to build up their cash holdings, we observe a positive impact on investments for small corporations in these countries. Thus, the results suggest that corporations that were the most financially constrained before the LTRO intervention and are located in countries where we expect the LTRO intervention to be most effective (low early repayment countries) were helped in terms of the fulfillment of their investment goals. Although we find a decrease in investment for corporations in the medium early repayment countries (Panel B), we again find a positive impact on leverage, and therefore a transmission of LTRO funds, for small corporations. For corporations in the high early LTRO repayment group, we find an increase in investment for both small and large corporations, reconfirming that the signaling effect dominated in relatively safe countries.

Overall, and as evidenced by the increase in leverage, the findings in this section suggest that the real LTRO liquidity injections into banks were transmitted to corporate borrowing in GIIPS countries, where the banks used the LTRO funds for a relatively longer time period. Small corporations in the low early-repayment countries (i.e., Portugal, Italy, and Greece) also increased their investment after LTRO liquidity injections, which suggests the role of both real liquidity transmission and signaling effects. However, for non-GIIPS countries, the LTRO liquidity injections may instead have stimulated corporate investment through the signaling channel. German corporations, typically dealing with the high-repayment banks, increased their investment after LTRO liquidity 
injections even when there was no significant increase in leverage. Because the signaling channel, in general, may not only be determined by the ECB's monetary policy but also, in particular, by (local) national fiscal policies we next address the significance of the signaling channel for the effectiveness of the LTRO intervention by investigating the role of accommodative versus contractionary fiscal policies.

\subsection{The Role of Fiscal Policy}

Fiscal and monetary policies interact closely in reality, and these interactions can lead to very different outcomes than those predicted by the analysis of either policy in isolation (Dixit and Lambertini (2003)). Whereas the ECB launched a plethora of expansionary monetary interventions since the onset of the European sovereign debt, many member states in the Eurozone implemented austerity plans to cut government spending, intending to reduce their fiscal deficits and sovereign debt. One unique feature of the Eurozone economies is that although the ECB determines the common monetary policy for all member countries, each member state's government decides its own fiscal policy. This feature limits the flexibility of economic policymaking and introduces greater complexity to overall economic policies, with attendant spillover effects on product supply and consumer demand in the Eurozone. In particular, fiscal policies that do not support a monetary policy may offset the positive liquidity shock created by the ECB because it weakens the signaling effect and potentially also hurts the corporations even more. Therefore, we expect the decrease in investment to be most pronounced when there is a lack of coordination between the monetary and fiscal policies, i.e., expansionary monetary policy through the unconventional LTROs, accompanied by a contractionary fiscal policy in a particular country. However, when there is closer coordination between monetary and fiscal policies, we expect to observe increased corporate investment following the implementation of the ECB's unconventional monetary policy.

To investigate the role of fiscal policy, we analyze the impact of the country-level changes in corporate tax rates and government investment expenditures as proxies for the country-specific fiscal policies. Accordingly, contractionary fiscal policies involve increasing corporate taxation, decreasing government spending (investment expenditures), or both. Specifically, we measure the changes in tax policy as the country-specific change in the corporate tax rate from one year before to one year after the first LTRO intervention, i.e., the change from 2010-Q4 to 2012-Q4. Next, we 
classify corporations into subsamples based on whether their local national government increased, maintained or decreased the corporate tax rate and conduct our investment analysis within the subsamples of corporations located in Increased Corporate Tax, Unchanged Corporate Tax and Decreased Corporate Tax countries, respectively. ${ }^{31}$ To account for governments' spending policies, we again use the country-specific change in the government investment expenditures from one year before to one year after the first LTRO intervention, i.e., the change from 2010-Q4 to 2012-Q4. Specifically, we use the median of quarterly government investment expenditures to GDP ratio for each year to classify corporations into subsamples based on whether their local national government increased or decreased the amount of investment expenditures between 2010-Q4 to 2012-Q4. Next, we conduct our investment analysis within the subsamples of corporations located in Increased Government Investment, and Decreased Government Investment countries, respectively.

The results of this analysis of fiscal policies are presented in Table 10. In Panel A, the analysis is conducted in the baseline Eurozone sample, with LTRO-Country Uptake as a proxy for the monetary policy. As we can see from Models 1 and 5, we find significant negative coefficients for LTRO-Country Uptake for corporations in countries that increased their corporate taxes or decreased government investment. These results indicate that in countries with relatively contractionary fiscal policies, corporations decreased their investments following the LTRO liquidity injection. Furthermore, for Models 3 and 4, we find positive and significant coefficients for LTROCountry Uptake for corporations in countries that decreased corporate taxes or increased government investment. Thus, we find clear evidence that when governments adopted accommodative fiscal policies in the face of substantial monetary stimulus, corporations actually increased investment along with their local banks' uptake of the LTRO liquidity injections. In Panel B, we further investigate the interaction of monetary-fiscal policy in the bank-firm linked sample, with LTROBank Uptake as a proxy for the monetary policy. We again find some evidence that corporations in countries with accommodative fiscal policies increased/or had a smaller decrease in investment following the LTRO liquidity injections. However, the results are not as robust as those for the full sample with the LTRO-Country Uptake as a proxy for monetary policy, which may indicate the differential impact of the signaling versus the transmission channels of monetary policy: The

\footnotetext{
${ }^{31}$ During the period 2010-Q4 to 2012-Q4, France and Portugal increased and Finland, Netherlands and Greece decreased the corporate tax rate. The remaining countries did not change corporate tax rates.
} 
ECB monetary policy can be transmitted as a positive signal to the corporate level only if the local government sends an accommodative signal at the same time. In contrast, the actual transmission effect may still be present but to a much smaller degree, despite accommodative fiscal policies, so long as it is ensured that the corporations actually have access to the additional funds stemming from the ECB policy. Overall, the results in this section provide additional evidence of the potential of increased corporate investment in countries with coordinated monetary-fiscal policies.

\section{Conclusions}

Since the 2008 global financial crisis, major central banks around the world have virtually exhausted their conventional monetary policy tools; specifically, sovereign interest rates have reached the zero bound in many countries. Consequently, central banks have resorted to unconventional monetary policies such as asset purchases and liquidity injections, and seem willing to do "whatever it takes" including targeting even negative interest rate policies. There have been many studies on how such unconventional monetary policies affect asset prices along with how these monetary interventions to commercial banks, i.e., the entities that are the most directly affected by such policies, are transmitted. Remarkably, there has been relatively little discussion of how individual corporations in these economies are affected, either positively or negatively, by these policies, particularly with regard to actual liquidity injections. In this paper, we fill this gap and investigate how non-financial corporations in the Eurozone, and the EU more generally, react to unconventional monetary interventions by the ECB. To this end, we provide direct evidence of the effects of central bank liquidity injections on the real economy.

Examining the impact of the ECB's LTRO, we find that non-financial corporations in the Eurozone held more cash after these massive LTRO liquidity injections. The cash increase is closely related to the actual uptake of the banks in the corporation's country of domicile, under the unconventional LTRO program. In other words, when the commercial banks in a country received more funds from the ECB through the LTRO programs, non-financial corporations in the same country ended up with more cash. However, in terms of the real economy, we do not find evidence of a positive impact of the liquidity intervention on corporate investment or employment for the average corporation. Specifically, we find that corporations decreased their investment when the 
banks in their home countries received more money from the unconventional LTRO program. This reduction in investment existed for corporations regardless of whether they had a bank relationship. However, the negative investment effect of the unconventional LTROs varies across repayment choices. Corporate investments are positively associated with LTRO uptake if their associated banks repaid ECB LTRO funds earlier. Furthermore, we find that when governments adopted accommodative fiscal policies at the same time, corporate investment increased in response to the banks' LTRO uptakes. In contrast, counterfactual analysis suggests that the LTRO intervention helped corporations in the Eurozone sustain their investments better than European corporations outside the Eurozone at the onset of the European Sovereign Debt Crisis.

Our findings indicate that non-financial corporations in the Eurozone were indeed affected by ECB liquidity injections in terms of cash holdings and leverage. However, at least part of the impact turned out to be different from what the ECB intended. If corporations simply hoarded the cash that they borrowed from banks instead of hiring or investing, then the real economy could not have benefited from the flood of liquidity circulating around the banking system and on corporate balance sheets. Overall, while our findings demonstrate the ability of monetary interventions to decelerate economic decline, our study casts doubt on the effectiveness of certain unconventional monetary policies in improving real economic output. Fiscal policies and other unconventional monetary policies, including the more aggressive Targeted LTRO, may have resulted in different outcomes, but they too should be carefully discussed and analyzed. We leave these issues for future study once additional data become available. 


\section{References}

Acharya, Viral V., Tim Eisert, Christian Eufinger, and Christian Hirsch, 2016, "Real Effects of the Sovereign Debt Crisis in Europe: Evidence from Syndicated Loans," Working paper.

— , 2017, "Whatever it Takes: The Real Effects of Unconventional Monetary Policy," Working paper.

Acharya, Viral V., Björn Imbierowicz, Sascha Steffen, and Daniel Teichmann, 2015, "Does Lack of Financial Stability Impair the Transmission of Monetary Policy?," Working paper.

Acharya, Viral V., Diane Pierret, and Sascha Steffen, 2016, "Lender of Last Resort versus Buyer of Last Resort-Evidence from the European Sovereign Debt Crisis," Working paper.

Acharya, Viral V., and Sascha Steffen, 2015, "The "Greatest" Carry Trade Ever? Understanding Eurozone Bank Risks," Journal of Financial Economics 115, 215-236.

Agarwal, Sumit, Souphala Chomsisengphet, Neale Mahoney, and Johannes Stroebel, 2015, "Regulating Consumer Financial Products: Evidence from Credit Cards," Quarterly Journal of Economics 130, 111164.

Akdoğu, Evrim, and Peter MacKay, 2008, "Investment and Competition," Journal of Financial and Quantitative Analysis 43, 299-330.

Almeida, Heitor, and Murillo Campello, 2007, "Financial Constraints, Asset Tangibility, and Corporate Investment," Review of Financial Studies 20, 1001-1024.

Amiti, Mary, and David E. Weinstein, 2017, "How Much do Idiosyncratic Bank Shocks Affect Investment? Evidence from Matched Bank-Firm Data," Journal of Political Economy, forthcoming.

Andrade, Philippe, Christophe Cahn, Henri Fraisse, and Jean-Stéphane Mésonnier, 2015, "Can the Provision of Long-term Liquidity Help to Avoid a Credit Crunch? Evidence from the Eurosystem's LTROs," Working paper.

Azar, José A., Jean-Francois Kagy, and Martin C. Schmalz, 2016, "Can Changes in the Cost of Carry Explain the Dynamics of Corporate "Cash" Holdings?," The Review of Financial Studies 29, 2194-2240.

Bates, Thomas W., Kathleen M. Kahle, and Rene M. Stulz, 2009, "Why do U.S. Firms hold so much more Cash than They Use to?," Journal of Finance 64, 1985-2021.

Berger, Allen N., and Raluca A. Roman, 2016, "Did Saving Wall Street Really Save Main Street? The Real Effects of TARP on Local Economic Conditions," Journal of Financial and Quantitative Analysis, forthcoming.

Bergman, Nittai, Rajkamal Iyer, and Richard T. Thakor, 2017, "The Effect of Cash Injections: Evidence from the 1980s Farm Debt Crisis," Working paper.

Bocola, Luigi, 2016, "The Pass-Through of Sovereign Risk," Journal of Political Economy 124, 879-926.

Bolton, Patrick, Hui Chen, and Neng Wang, 2013, "Market Timing, Investment, and Risk Management," Journal of Financial Economics 109, 40-62.

— , 2014, "Debt, Taxes, and Liquidity," Working Paper.

Bottero, Margherita, Simone Lenzu, and Filippo Mezzanotti, 2017, "Sovereign debt exposure and the bank lending channel: impact on credit supply and the real economy," Working paper.

Buca, Andra, and Philip Vermeulen, 2017, "Corporate investment and bank-dependent borrowers during the recent financial crisis," Journal of Banking and Finance 78, 164-180.

Carpinelli, Luisa, and Matteo Crosignani, 2017, "The Effect of Central Bank Liquidity Injections on Bank Credit Supply," Working paper.

Chakraborty, Indraneel, Itay Goldstein, and Andrew MacKinlay, 2017, "Monetary Stimulus and Bank Lending," Working paper.

Chava, Sudheer, and Amiyatosh Purnanandam, 2011, "The Effect of Banking Crisis on Bank-Dependent Borrowers," Journal of Financial Economics 99, 116-135.

Chava, Sudheer, and Michael Roberts, 2008, "How does Financing Impact Investment? The Role of Debt Covenants," Journal of Finance 63, 2085-2121.

Chen, Yangyang, Paul Y. Dou, Rhee, Cameron Truong, and Madhu Veeraraghavan, 2015, "National Culture and Corporate Cash Holdings around the World," Journal of Banking and Finance 50, 1-18.

Chodorow-Reich, Gabriel, 2014, "The employment effects of credit market disruptions: Firm-level evidence from the 2008-9 financial crisis," Quarterly Journal of Economics 129, 1-58. 
Christiano, Lawrence J., 1994, "Modeling the Liquidity Effect of a Money Shock," Springer-Verlag 413, 61-124.

Cingano, Federico, Francesco Manaresi, and Enrico Sette, 2016, "Does Credit Crunch Investment Down? New Evidence on the Real Effects of the Bank-Lending Channel," Review of Financial Studies 29, 2737-2773.

Darracq-Paries, Matthieu, and Roberto A. De Santis, 2015, "A Non-Standard Monetary Policy Shock: The ECB's 3-Year LTROs And the Shift In Credit Supply," Journal of International Money and Finance 54, $1-34$.

De Marco, Filippo, 2017, "Bank Lending and the European Sovereign Debt Crisis," Journal of Financial and Quantitative Analysis, forthcoming.

De Pooter, Michiel, Rebecca DeSimone, Robert F. Martin, and Seth Pruitt, 2015, "Cheap Talk and the Efficacy of the ECBs Securities Market Programme: Did Bond Purchases Matter?," Working paper.

De Pooter, Michiel, Robert F. Martin, and Seth Pruitt, 2016, "The Liquidity Effects of Official Bond Market Intervention," Working paper.

Dixit, Avinash, and Luisa Lambertini, 2003, "Interactions of Commitment and Discretion in Monetary and Fiscal Policies," American Economic Review 93, 1522-1542.

Drechsler, Itamar, Thomas Drechsel, David Marques-Ibanez, and Philipp Schnabl, 2016, "Who Borrows from the Lender of Last Resort?," Journal of Finance 71, 1933-1974.

Duchin, Ran, Oguzhan Ozbas, and Berk A. Sensoy, 2010, "Costly External Finance, Corporate Investment, and the Subprime Mortgage Credit Crisis," Journal of Financial Economics 97, 418-435.

Duchin, Ran, and Denis Sosyura, 2015, "Safer Ratios, Riskier Portfolios: Banks Response to Government Aid," Journal of Financial Economics 113, 1-28.

Eser, Fabian, and Bernd Schwaab, 2016, "Evaluating the Impact of Unconventional Monetary Policy Measures: Empirical Evidence from the ECB's Securities Markets Programme," Journal of Financial Economics 119, 147-167.

FitchRatings, 2012, "European Banks's Use of LTRO," Report.

Foley-Fisher, Nathan, Rodney Ramcharan, and Edison Yu, 2016, "The Impact of Unconventional Monetary Policy on Firm Financing Constraints: Evidence from the Maturity Extension Program," Journal of Financial Economics 122, 409-429.

Garcia-de Andoain, Carlos, Florian Heider, Marie Hoerova, and Simone Manganelli, 2016, "Lending-ofLast-Resort is as Lending-of-Last-Resort does: Central Bank Liquidity Provision and Interbank Market Functioning in the Euro Area," Journal of Financial Intermediation 28, 32-47.

Garcia-Posada, Miguel, and Marcos Marchetti, 2016, "The Bank Lending Channel of Unconventional Monetary Policy: The Impact of the VLTROs on Credit Supply in Spain," Economic Modelling 58, 427-441.

Gennaioli, Nicola, Yueran Ma, and Andrei Shleifer, 2016, "Expectations and Investment," NBER Macroeconomics Annual 30, 379-442.

Gorton, Gary, and Andrew Metrick, 2013, "The Federal Reserve and Panic Prevention: The Roles of Financial Regulation and Lender of Last Resort," Journal of Economic Perspectives 27, 45-64.

Graham, John R., Mark T. Leary, and Michael R. Roberts, 2014, "How Does Government Borrowing Affect Corporate Financial and Investment Policies?," Working paper.

Guiso, Luigi, and Giuseppe Parigie, 1999, "Investment and Demand Uncertainty," The Quarterly Journal of Economics 114, 185-227.

Harford, Jarrad, and Vahap B. Uysal, 2014, "Bond Market Access and Investment," Journal of Financial Economics 112, 147-163.

Iyer, Rajkamal, Jose-Luis Peydro, Samuel da Rocha-Lopes, and Antoinette Schoar, 2014, "Interbank Liquidity Crunch and the Firm Credit Crunch: Evidence from the 20072009 Crisis," Review of Financial Studies $27,347-372$.

Kahle, Kathleen M., and Rene M. Stulz, 2013, "Access to Capital, Investment, and the Financial Crisis," Journal of Financial Economics 110, 280-299.

Kasahara, Hiroyuki, Yasuyuki Sawada, and Michio Suzuki, 2016, "The Effect of Bank Recapitalization Policy on Corporate Investment: Evidence from a Banking Crisis in Japan," Working paper.

Kydland, Finn E., and Carlos E.J.M. Zarazaga, 2016, "Fiscal Sentiment and the Weak Recovery from the Great Recession: A Quantitative Exploration," Journal of Monetary Economics 79, 109-125. 
Opler, Tim, Lee Pinkowitz, Rene Stulz, and Rohan Williamson, 1999, "The Determinants and Implications of Corporate Cash Holdings," Journal of Financial Economics 52, 3-46.

Pelizzon, Loriana, Marti G. Subrahmanyam, Davide Tomio, and Jun Uno, 2016, "Sovereign Credit Risk, Liquidity, and ECB Intervention: Deus ex Machina?," Journal of Financial Economics 122, 86-115.

Romer, Christina D., and David H. Romer, 2013, "The Most Dangerous Idea in Federal Reserve History: Monetary Policy Doesn't Matter," American Economic Review 103, 55-60.

Subrahmanyam, Marti G., Dragon Y. Tang, and Sarah Q. Wang, 2017, "Credit Default Swaps, Exacting Creditors and Corporate Liquidity Management," Journal of Financial Economic 124, 395-414.

Trebesch, Christoph, and Jeromin Zettelmeyer, 2016, "ECB Interventions in Distressed Sovereign Debt Markets: The Case of Greek Bonds," Working paper.

Valta, Philip, 2012, "Competition and the Cost of Debt," Journal of Financial Economics 105, 661-682. 
Two LTROs with

6 month maturity

\section{Two LTROs \\ with 3 year maturity}

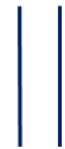

Two LTROs with 12 month maturity
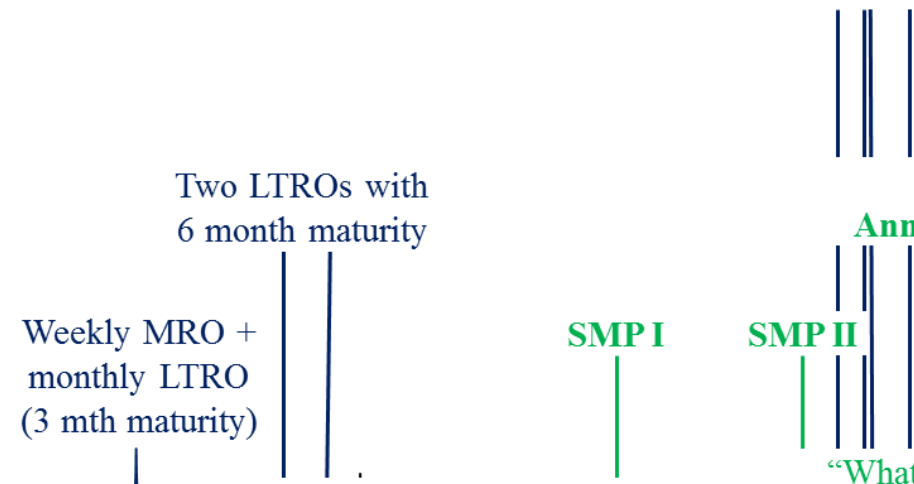

Fixed rate full Fixed rate full Fixed rate full
allotment - MRO allotment - LTRO

Fixed rate full SMP I

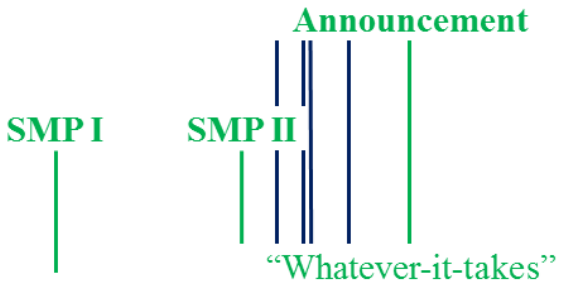

OMT

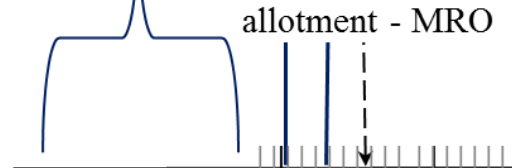

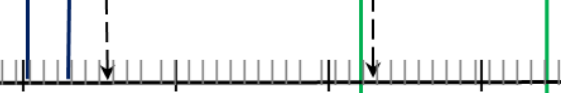

2000-2007 2008

2009

2010

2011 speech by Draghi

\section{Two initial rounds of targeted LTROs}

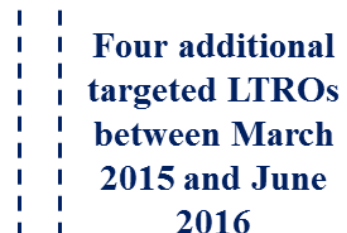
2016

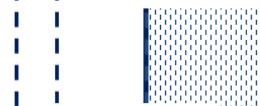

OMT

Approved

110

APP

Implementation

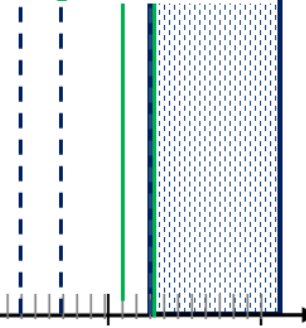

$2014 \quad 2015 \quad 2016$

Figure 1

ECB's unconventional monetary policies

This figure outlines the timeline of recent unconventional monetary policies implemented by the European Central Bank (ECB). $M R O$ labels the standard Marginal Refinancing Operations that are conducted on a weekly basis. LTROs refers to Longerterm Refinancing Operations, while TLTROs refers to the recently introduced Targeted Longer-Term Refinancing Operations. $S M P$, the Securities Markets Program, was recently replaced by the Outright Monetary Transactions (OMT) program. APP represents the most recently introduced Asset Purchase Program, that is still under way. The "whatever-it-takes" event refers to a speech made by Mario Draghi, the President of the ECB, at the Global Investment Conference, London, July $26,2012$. 
High Sovereign Risk

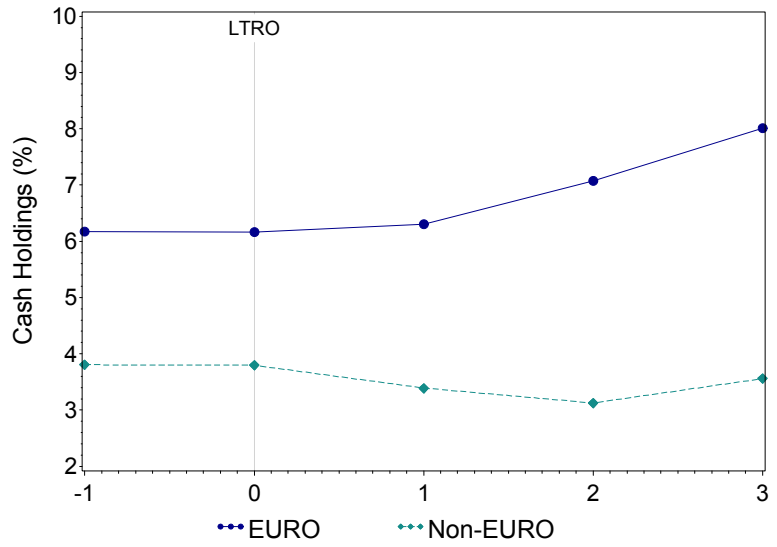

(a) Corporate cash holdings in high-sovereign-risk countries.

High Sovereign Risk

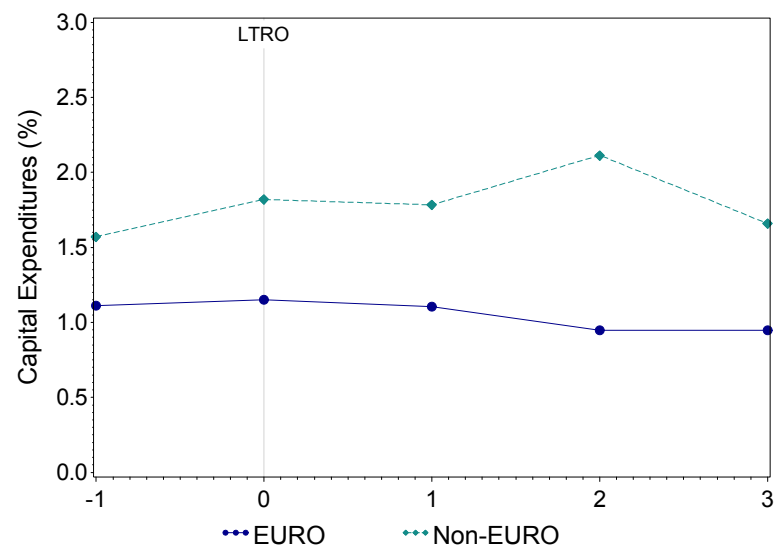

(c) Corporate investment in high-sovereign-risk countries.

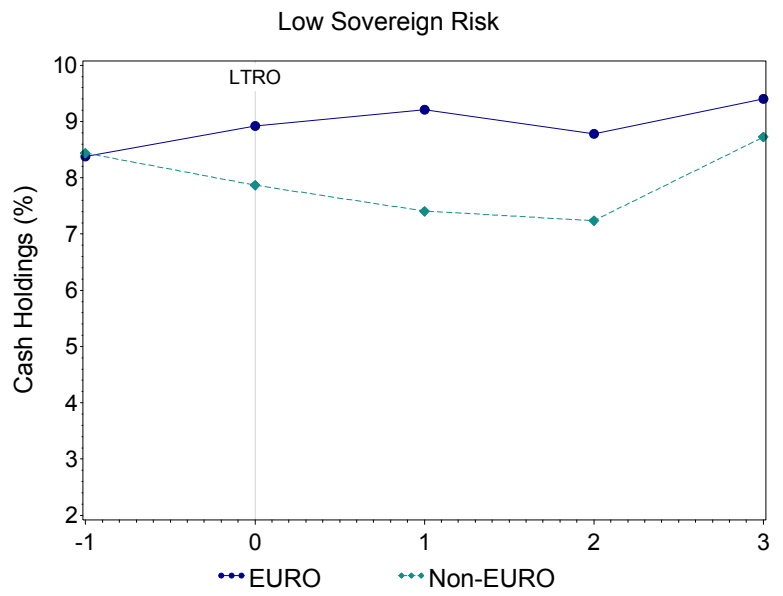

(b) Corporate cash holdings in low-sovereign-risk countries.

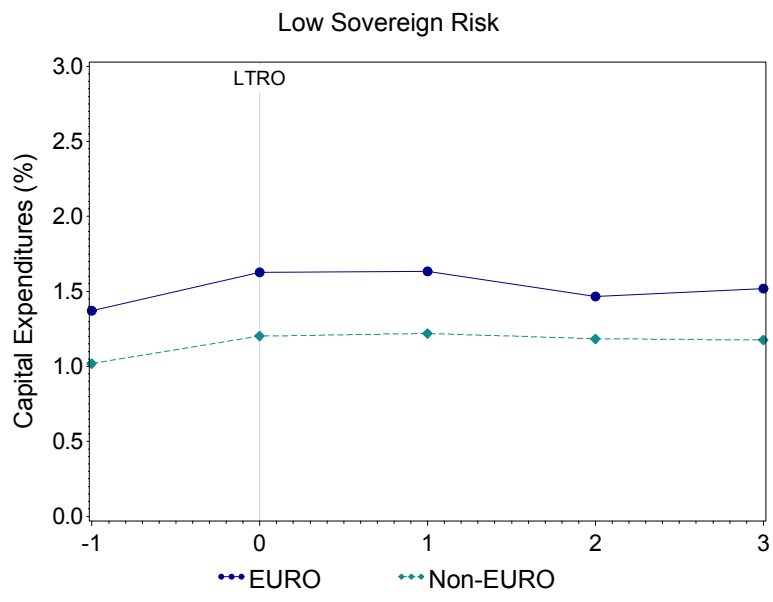

(d) Corporate investment in low-sovereign-risk countries.

Figure 2

Time series of corporate cash holdings and investment before and after the LTRO intervention

The figures outline the development in corporations' cash holdings (cash to assets ratio) and investment (capital expenditure to assets ratio) in the European Union (both in the Eurozone and outside) around the LTRO intervention in $2011 / 2012$. Time "0" indicates the year of the first LTRO intervention (2011) and the variable for cash (investment) is the average of the quarterly observations of the corporations' cash to assets (capital expenditure to assets) ratio. Similarly, times "-1" ("1", "2", "3") indicate the year 2010 (2012, 2013, 2014). We separate corporations into EURO and Non-EURO samples based upon whether they are located in a Eurozone, or non-Eurozone, country respectively. In addition, we provide the analyses separately for High Sovereign Risk and Low Sovereign Risk countries, the separation being based upon countries' CDS spreads in the pre-intervention period (2009 and 2010). 
Table 1

Liquidity injection from the ECB's three-year Longer-term Refinancing Operations

\begin{tabular}{|c|c|c|c|c|}
\hline Country & $\begin{array}{c}\text { LTRO I: Dec. } 2011 \\
\text { EUR billion } \\
(1)\end{array}$ & $\begin{array}{c}\text { LTRO II: Feb. } 2012 \\
\text { EUR billion } \\
(2)\end{array}$ & $\begin{array}{c}\text { Total } \\
\text { EUR billion } \\
(3)\end{array}$ & $\begin{array}{c}\text { LTRO-Country Uptake } \\
\text { \% of government debt } \\
(4)\end{array}$ \\
\hline Austria & 3.66 & 7.83 & 11.49 & 4.82 \\
\hline Belgium & 45.28 & 43.71 & 88.99 & 25.02 \\
\hline France & 5.59 & 6.52 & 12.12 & 0.61 \\
\hline Germany & 12.25 & 13.13 & 25.38 & 1.67 \\
\hline Greece & $60.94 \S$ & & $60.94^{a}$ & 25.54 \\
\hline Ireland & 21.91 & 17.62 & 39.52 & 22.33 \\
\hline Italy & 172.08 & 128.11 & 300.20 & 15.92 \\
\hline Netherlands & 8.86 & 1.96 & 10.81 & 2.58 \\
\hline Portugal & 24.54 & 24.76 & 49.30 & 29.37 \\
\hline Spain & 153.21 & 165.53 & 318.74 & 51.44 \\
\hline Total & 508.32 & 409.17 & 917.49 & \\
\hline
\end{tabular}

This table presents data on the liquidity injections that Eurozone countries obtained from the three-year Longer-term Refinancing Operations (LTROs) initiated by the European Central Bank (ECB) on December 21, 2011 (LTRO I) and February 29, 2012 (LTRO II), respectively. The term Uptake refers to the amount that banks in the respective country obtained through LTRO I and II, with the numbers given in billions of Euros. The Total refers to the total uptake from the two LTROs. In column 4, we scale the Total Uptake for each country by the country's central government debt obligations, as of December 2011. The information about the country-specific LTRO uptake is based upon hand-collected data from Bloomberg, as well as central bank announcements and public commentaries. The information for government debt by country is obtained from the World Bank Database.

$\S$ In the case of Greece, we only have information about the total LTRO amount that, besides the three-year LTROs, also includes the standard one-month and three-month LTROs. As we cannot separate the latter, the number is not directly comparable to the uptake numbers for the other countries. 
Table 2

Summary statistics

\begin{tabular}{|c|c|c|c|c|c|c|c|c|c|c|c|c|}
\hline Country & DEU & FRA & ITA & GRC & NLD & FIN & ESP & BEL & AUT & IRL & PRT & Total \\
\hline Cash & 10.07 & 10.23 & 6.96 & 4.15 & 6.82 & 8.06 & 7.08 & 8.01 & 8.85 & 11.37 & 4.00 & 8.29 \\
\hline Investments & 3.31 & 3.05 & 2.47 & 2.48 & 3.11 & 3.39 & 3.29 & 3.85 & 5.41 & 2.56 & 3.16 & 3.12 \\
\hline Wages & 1.85 & 1.86 & 2.30 & 1.19 & 2.88 & 2.16 & 3.30 & 2.10 & 3.15 & 1.30 & 2.77 & 2.07 \\
\hline Leverage & 16.40 & 19.06 & 27.63 & 33.97 & 22.80 & 23.86 & 28.33 & 22.42 & 22.35 & 21.28 & 40.2 & 22.07 \\
\hline Net Debt & 55.58 & 59.01 & 64.26 & 60.54 & 58.65 & 57.39 & 63.95 & 56.70 & 55.96 & 55.04 & 73.59 & 59.01 \\
\hline Short-term Debt & 0.05 & 0.06 & 0.11 & 0.16 & 0.05 & 0.07 & 0.08 & 0.05 & 0.08 & 0.03 & 0.14 & 0.07 \\
\hline Bank Debt & 11.36 & 9.97 & 20.99 & 21.78 & 13.38 & 15.49 & 22.47 & 11.43 & 14.23 & 12.56 & 22.58 & 14.54 \\
\hline Size & 4.53 & 4.59 & 5.70 & 4.84 & 6.32 & 4.99 & 6.42 & 5.15 & 5.44 & 5.69 & 5.92 & 5.02 \\
\hline Market-to-Book & 120.0 & 121.6 & 114.4 & 95.2 & 128.9 & 125.9 & 123.4 & 114.7 & 114.7 & 128.9 & 106.9 & 117.9 \\
\hline Cash Flow & 4.84 & 3.57 & 3.07 & 1.62 & 5.80 & 7.21 & 5.89 & 4.81 & 5.36 & 2.90 & 2.96 & 4.10 \\
\hline Ind. Sigma & 7.61 & 5.69 & 3.20 & 3.07 & 5.53 & 4.43 & 2.59 & 4.48 & 3.30 & 4.55 & 2.97 & 4.85 \\
\hline NWC & 6.17 & 1.90 & 0.85 & 5.11 & 2.13 & 3.75 & -2.08 & -0.58 & 3.38 & 0.55 & -7.76 & 2.75 \\
\hline R\&D/Sales & 0.00 & 0.00 & 0.00 & 0.00 & 0.00 & 0.47 & 0.00 & 0.00 & 0.00 & 0.00 & 0.00 & 0.00 \\
\hline Acquisition & 0.00 & 0.00 & 0.00 & 0.00 & 0.00 & 0.00 & 0.00 & 0.00 & 0.00 & 0.00 & 0.00 & 0.00 \\
\hline Sov. CDS & 10.55 & 11.71 & 52.00 & 56.40 & 29.95 & 13.09 & 50.74 & 24.96 & 10.35 & 27.89 & 36.86 & 17.62 \\
\hline Sov. Export & 42.25 & 27.12 & 26.21 & 22.10 & 69.27 & 39.08 & 25.51 & 76.44 & 51.00 & 90.48 & 29.91 & 31.12 \\
\hline Corp. Tax & 30.17 & 35.42 & 31.40 & 29.00 & 25.50 & 26.00 & 30.00 & 33.99 & 25.00 & 12.50 & 29.00 & 34.43 \\
\hline Gov. Inv. & 8.68 & 15.81 & 11.69 & 19.42 & 15.69 & 15.13 & 16.45 & 8.65 & 11.73 & 13.72 & 14.80 & 14.26 \\
\hline Gov. Debt & 67.06 & 67.01 & 105.9 & 126.6 & 50.27 & 41.69 & 50.08 & 101.8 & 73.17 & 32.54 & 69.23 & 69.88 \\
\hline$\# \mathrm{~N}$ & 31333 & 30712 & 10825 & 9810 & 6594 & 6000 & 5443 & 4939 & 3376 & 2519 & 2392 & 113943 \\
\hline \# Corp. & 837 & 837 & 285 & 233 & 190 & 143 & 136 & 124 & 92 & 75 & 57 & 3009 \\
\hline
\end{tabular}

This table provides sample averages (medians) of corporate characteristics for each country in our sample of Eurozone corporations. Cash is the ratio of cash and short-term investments to total assets. Investments is the ratio of capital expenditure to total assets. Wages is the total salaries and wages, given in logarithms. Leverage is the book value of the long-term debt plus debt in current liabilities, divided by total assets. Net Debt is the ratio of current plus non-current liabilities minus cash holdings to total assets. Short-term Debt is the ratio of current liabilities to total assets. Bank Debt is the amount of debt from bank loans, divided by total assets. Size is the total assets, given in logarithms. Market-to-Book is the book value of assets minus the book value of equity plus the market value of equity, all divided by the book value of assets. Cash Flow is the ratio of the cash flow to total assets, where cash flow is the earnings after interest and related expenses, income taxes, and dividends. Industry Sigma is industry cash flow risk, measured by the mean cash flow volatility across two-digit SIC codes. Net Working Capital (NWC) is the difference between current assets and current liabilities net of cash, divided by total assets. RED/Sales is the ratio of R\&D to sales. Acquisition is the ratio of acquisitions to total assets. Sovereign CDS is the five-year sovereign CDS spread for the country. Sovereign Export is the country's export-to-GDP ratio. Corporate Tax is the country's corporate tax rate given as a percentage. Government Investment is the country's government investment expenditures to GDP ratio, given as a percentage. Government Debt is the country's central government debt to GDP ratio, given as a percentage. The sample period for each country is 2002-2014, and the variables are based on quarterly observations. The firm fundamental data are obtained from Compustat Global, while country specific data are obtained from Markit, the World Bank, as well as, the ECB statistics Warehouse. For any data unavailable for a specific quarter, we replace the missing values with yearly observations. Ratios are given in percentages. 
Table 3

LTRO uptake and bank debt reliance effect on cash holdings

\begin{tabular}{|c|c|c|c|}
\hline & \multirow{2}{*}{$\begin{array}{c}\text { Cash } \\
\text { Full Sample } \\
(1)\end{array}$} & \multicolumn{2}{|c|}{ Cash } \\
\hline & & $\begin{array}{c}\text { High Bank Debt } \\
(2)\end{array}$ & $\begin{array}{c}\text { Low Bank Debt } \\
\text { (3) }\end{array}$ \\
\hline LTRO-Country Uptake & $\begin{array}{c}2.169^{* * *} \\
(0.56)\end{array}$ & $\begin{array}{l}2.609^{* * *} \\
(0.61)\end{array}$ & $\begin{array}{l}0.166 \\
(0.98)\end{array}$ \\
\hline Industry Sigma & $\begin{array}{l}0.021 \\
(0.01)\end{array}$ & $\begin{array}{c}0.102^{* * *} \\
(0.02)\end{array}$ & $\begin{array}{c}-0.016 \\
(0.02)\end{array}$ \\
\hline Cash Flow & $\begin{array}{l}0.001 \\
(0.00)\end{array}$ & $\begin{array}{l}0.000 \\
(0.00)\end{array}$ & $\begin{array}{l}0.004 \\
(0.00)\end{array}$ \\
\hline Market-to-Book & $\begin{array}{c}0.014^{* * *} \\
(0.00)\end{array}$ & $\begin{array}{c}0.015^{* * *} \\
(0.00)\end{array}$ & $\begin{array}{c}0.015^{* * *} \\
(0.00)\end{array}$ \\
\hline Size & $\begin{array}{c}-0.113 \\
(0.07)\end{array}$ & $\begin{array}{c}-0.714^{* * *} \\
(0.10)\end{array}$ & $\begin{array}{c}0.662^{* * *} \\
(0.12)\end{array}$ \\
\hline Net Working Capital & $\begin{array}{c}-0.124^{* * *} \\
(0.00)\end{array}$ & $\begin{array}{c}-0.064^{* * *} \\
(0.00)\end{array}$ & $\begin{array}{c}-0.188^{* * *} \\
(0.00)\end{array}$ \\
\hline Capital Expenditure & $\begin{array}{c}-0.121^{* * *} \\
(0.00)\end{array}$ & $\begin{array}{c}-0.037^{* * *} \\
(0.01)\end{array}$ & $\begin{array}{c}-0.190^{* * *} \\
(0.01)\end{array}$ \\
\hline Leverage & $\begin{array}{c}-0.167^{* * *} \\
(0.00)\end{array}$ & $\begin{array}{c}-0.140^{* * *} \\
(0.00)\end{array}$ & $\begin{array}{c}-0.199 * * * \\
(0.00)\end{array}$ \\
\hline Div. Dummy & $\begin{array}{c}0.665^{* * *} \\
(0.08)\end{array}$ & $\begin{array}{c}0.388^{* * *} \\
(0.11)\end{array}$ & $\begin{array}{c}0.752^{* * *} \\
(0.12)\end{array}$ \\
\hline R\&D/Sales & $\begin{array}{c}0.015^{* * *} \\
(0.00)\end{array}$ & $\begin{array}{c}0.029 * * * \\
(0.00)\end{array}$ & $\begin{array}{c}0.019 * * * \\
(0.00)\end{array}$ \\
\hline Acquisition Activity & $\begin{array}{c}-0.023^{* * *} \\
(0.00)\end{array}$ & $\begin{array}{c}0.035^{* * *} \\
(0.01)\end{array}$ & $\begin{array}{c}-0.047^{* * *} \\
(0.01)\end{array}$ \\
\hline Sovereign CDS & $\begin{array}{c}1.491 * * * \\
(0.29)\end{array}$ & $\begin{array}{l}0.295 \\
(0.26)\end{array}$ & $\begin{array}{c}0.785^{* *} \\
(0.39)\end{array}$ \\
\hline Sovereign Export & $\begin{array}{c}0.552^{* *} \\
(0.24)\end{array}$ & $\begin{array}{c}-0.036^{* *} \\
(0.01)\end{array}$ & $\begin{array}{c}-0.053^{* * *} \\
(0.01)\end{array}$ \\
\hline Rated & $\begin{array}{c}-0.048^{* * *} \\
(0.01)\end{array}$ & $\begin{array}{l}0.846 \\
(0.52) \\
\end{array}$ & $\begin{array}{c}1.862^{* * * *} \\
(0.37)\end{array}$ \\
\hline Time fixed effects & Yes & Yes & Yes \\
\hline Firm fixed effects & Yes & Yes & Yes \\
\hline$R$-square & 0.767 & 0.589 & 0.778 \\
\hline$N$ & 82053 & 30126 & 43777 \\
\hline
\end{tabular}

This table presents estimates of the effect of the corporate reliance on bank debt and the liquidity uptake from the ECB's three-year Longer-term Refinancing Operations (LTROs) on corporate cash holdings in a sample of corporations located in the Eurozone. Cash is defined as cash and cash equivalents, scaled by total assets. Bank Debt is the debt from bank loans, divided by total assets. Model 1 represents our base case cash model that, in addition to basic cash-holding determinants, includes the country-specific controls, Sovereign CDS and Sovereign Export. In Models 2 and 3, corporations are separated into those with High and Low Bank Debt ratios, based upon their bank debt ratios one year before the first three-year LTRO intervention (Q4-2010). The variable LTRO-Country Uptake is equal to zero until Q4-2011, and is equal to the country-specific total LTRO uptake amount, scaled by the central government debt of the country, thereafter. The sample period is 2002-2014, based on quarterly observations. (*** denotes significance at the $1 \%$ level, $* *$ significance at the $5 \%$ level, and $*$ significance at the $10 \%$ level. The numbers in parentheses are standard errors.) 
Table 4

LTRO uptake effect on debt financing policies

\begin{tabular}{|c|c|c|c|}
\hline & $\begin{array}{c}\text { Leverage } \\
(1)\end{array}$ & $\frac{\text { Net Debt }}{(2)}$ & $\frac{\text { Short-term Debt }}{(3)}$ \\
\hline LTRO-Country Uptake & $\begin{array}{c}4.420^{* * * *} \\
(0.65)\end{array}$ & $\begin{array}{c}3.554^{* * * *} \\
(1.15)\end{array}$ & $\begin{array}{c}-0.012^{* * *} \\
(0.00)\end{array}$ \\
\hline Industry Sigma & $\begin{array}{c}0.112^{* * *} \\
(0.01)\end{array}$ & $\begin{array}{c}0.106^{* * *} \\
(0.03)\end{array}$ & $\begin{array}{c}0.001^{* * *} \\
(0.00)\end{array}$ \\
\hline Cash Flow & $\begin{array}{c}-0.059^{* * *} \\
(0.00)\end{array}$ & $\begin{array}{c}-0.123^{* * *} \\
(0.00)\end{array}$ & $\begin{array}{c}-0.000^{* *} \\
(0.00)\end{array}$ \\
\hline Market-to-Book & $\begin{array}{c}0.008^{* * *} \\
(0.00)\end{array}$ & $\begin{array}{c}0.051^{* * *} \\
(0.00)\end{array}$ & $\begin{array}{l}0.000 \\
(0.00)\end{array}$ \\
\hline Size & $\begin{array}{c}2.640^{* * *} \\
(0.09)\end{array}$ & $\begin{array}{c}-3.271^{* * *} \\
(0.18)\end{array}$ & $\begin{array}{l}0.001 \\
(0.00)\end{array}$ \\
\hline Net Working Capital & $\begin{array}{c}-0.302^{* * *} \\
(0.00)\end{array}$ & $\begin{array}{c}-0.633^{* * *} \\
(0.00)\end{array}$ & $\begin{array}{c}-0.005^{* * *} \\
(0.00)\end{array}$ \\
\hline Capital Expenditure & $\begin{array}{c}-0.173^{* * *} \\
(0.01)\end{array}$ & $\begin{array}{c}-0.239^{* * *} \\
(0.01)\end{array}$ & $\begin{array}{c}-0.001^{* * *} \\
(0.00)\end{array}$ \\
\hline Cash & $\begin{array}{c}-0.228^{* * *} \\
(0.00)\end{array}$ & $\begin{array}{c}-0.549^{* * *} \\
(0.00)\end{array}$ & $\begin{array}{c}-0.002^{* * *} \\
(0.00)\end{array}$ \\
\hline Div. Dummy & $\begin{array}{c}-1.271^{* * *} \\
(0.09)\end{array}$ & $\begin{array}{c}-1.196 * * * \\
(0.18)\end{array}$ & $\begin{array}{c}-0.005^{* * *} \\
(0.00)\end{array}$ \\
\hline R\&D/Sales & $\begin{array}{c}-0.013^{* * *} \\
(0.00)\end{array}$ & $\begin{array}{c}0.013^{*} \\
(0.00)\end{array}$ & $\begin{array}{c}-0.000^{* * *} \\
(0.00)\end{array}$ \\
\hline Acquisition Activity & $\begin{array}{c}0.064^{* * *} \\
(0.01)\end{array}$ & $\begin{array}{l}0.007 \\
(0.01)\end{array}$ & $\begin{array}{c}-0.000 \\
(0.00)\end{array}$ \\
\hline Rated & $\begin{array}{l}0.020 \\
(0.34)\end{array}$ & $\begin{array}{c}-1.234^{*} \\
(0.65)\end{array}$ & $\begin{array}{c}-0.002 \\
(0.00)\end{array}$ \\
\hline Sovereign CDS & $\begin{array}{c}2.763^{* * *} \\
(0.28)\end{array}$ & $\begin{array}{l}0.559 \\
(0.45)\end{array}$ & $\begin{array}{l}0.010^{* * * *} \\
(0.00)\end{array}$ \\
\hline Sovereign Export & $\begin{array}{c}-0.106^{* * *} \\
(0.01)\end{array}$ & $\begin{array}{l}-0.021 \\
(0.02)\end{array}$ & $\begin{array}{l}-0.000 \\
(0.00)\end{array}$ \\
\hline Time fixed effects & Yes & Yes & Yes \\
\hline Firm fixed effects & Yes & Yes & Yes \\
\hline$R$-square & 0.795 & 0.778 & 0.801 \\
\hline$N$ & 82053 & 64040 & 57166 \\
\hline
\end{tabular}

This table presents estimates of the effect of the liquidity uptake from the ECB's three-year Longer-term Refinancing Operations (LTROs) on leverage in a sample of corporations located in the Eurozone. Leverage is measured as the book value of the longterm debt plus debt in current liabilities, divided by total assets. Net Debt is defined as the ratio of current plus non-current liabilities minus cash holdings, to total assets. Short-term Debt is defined as the ratio of current liabilities to total assets. The variable LTRO-Country Uptake is equal to zero until Q4-2011, and is equal to the country-specific total LTRO uptake amount, scaled by the central government debt of the country, thereafter. The sample period is 2002-2014, based on quarterly observations. (*** denotes significance at the $1 \%$ level, ${ }^{* *}$ significance at the $5 \%$ level, and ${ }^{*}$ significance at the $10 \%$ level. The numbers in parentheses are standard errors.) 
Table 5

LTRO uptake effect on investment and employment

\begin{tabular}{|c|c|c|c|c|}
\hline & \multicolumn{2}{|c|}{ Investments } & \multicolumn{2}{|c|}{ Wages } \\
\hline & $(1)$ & $(2)$ & $(3)$ & (4) \\
\hline \multirow[t]{2}{*}{ LTRO-Country Uptake } & $-1.695^{* * *}$ & $-1.350 * * *$ & -0.145 & -0.101 \\
\hline & $(0.24)$ & $(0.25)$ & $(0.08)$ & $(0.09)$ \\
\hline \multirow[t]{2}{*}{ Cash Flow } & $0.009 * * *$ & $0.005^{* *}$ & $-0.004^{* * *}$ & $-0.007 * * *$ \\
\hline & $(0.00)$ & $(0.00)$ & $(0.00)$ & $(0.00)$ \\
\hline \multirow[t]{2}{*}{ Market-to-Book } & $0.004^{* * *}$ & $0.004^{* * *}$ & $0.000^{* * *}$ & $0.000^{* *}$ \\
\hline & $(0.00)$ & $(0.00)$ & $(0.00)$ & $(0.00)$ \\
\hline \multirow[t]{2}{*}{ Size } & $0.127^{* * *}$ & $0.218^{* * *}$ & $0.675^{* * *}$ & $0.365^{* * *}$ \\
\hline & $(0.03)$ & $(0.04)$ & $(0.01)$ & $(0.02)$ \\
\hline \multirow[t]{2}{*}{ Leverage } & $-0.016^{* * *}$ & $-0.020^{* * *}$ & $-0.001^{* *}$ & -0.001 \\
\hline & $(0.00)$ & $(0.00)$ & $(0.00)$ & $(0.00)$ \\
\hline \multirow[t]{2}{*}{ Rated } & $0.332 * * *$ & $0.340 * *$ & 0.100 & $0.135^{* *}$ \\
\hline & $(0.12)$ & $(0.14)$ & $(0.06)$ & $(0.06)$ \\
\hline \multirow[t]{2}{*}{ Sovereign CDS } & $-0.771^{* * *}$ & $-0.670 * * *$ & $-0.102^{* *}$ & -0.055 \\
\hline & $(0.10)$ & $(0.10)$ & $(0.05)$ & $(0.05)$ \\
\hline \multirow[t]{2}{*}{ Sovereign Export } & $-0.014^{* * *}$ & $-0.017^{* * *}$ & $0.004^{*}$ & $0.004 *$ \\
\hline & $(0.00)$ & $(0.00)$ & $(0.00)$ & $(0.00)$ \\
\hline \multirow[t]{2}{*}{ Lagged Div. Dummy } & & $0.118^{* * *}$ & & -0.019 \\
\hline & & $(0.04)$ & & $(0.01)$ \\
\hline \multirow[t]{2}{*}{ Lagged R\&D/Sales } & & $0.580^{* * *}$ & & 0.028 \\
\hline & & $(0.13)$ & & $(0.05)$ \\
\hline \multirow[t]{2}{*}{ Lagged Acquisition Act } & & $-2.409^{* * *}$ & & $-0.481 * * *$ \\
\hline & & $(0.36)$ & & $(0.15)$ \\
\hline \multirow[t]{2}{*}{ Industry Sigma } & & $-0.014^{* *}$ & & -0.001 \\
\hline & & $(0.00)$ & & $(0.00)$ \\
\hline \multirow[t]{2}{*}{ Net Working Capital } & & $-0.007^{* * *}$ & & -0.000 \\
\hline & & $(0.00)$ & & $(0.00)$ \\
\hline \multirow[t]{2}{*}{ Sales } & & $0.148^{* * *}$ & & $0.356^{* * *}$ \\
\hline & & $(0.03)$ & & $(0.01)$ \\
\hline \multirow[t]{2}{*}{ Competition } & & 0.001 & & $-0.005^{* * *}$ \\
\hline & & $(0.00)$ & & $(0.00)$ \\
\hline Time fixed effects & Yes & Yes & Yes & Yes \\
\hline Firm fixed effects & Yes & Yes & Yes & Yes \\
\hline$R$-square & 0.568 & 0.597 & 0.787 & 0.790 \\
\hline$N$ & 86392 & 64635 & 51997 & 47910 \\
\hline
\end{tabular}

This table presents estimates of the effect of the liquidity uptake from the ECB's three-year Longer-term Refinancing Operations (LTROs) on corporate investment and employment compensation in a sample of corporations located in the Eurozone. Our measure for investment is Investments, which is the corporation's capital expenditure, scaled by total assets. Our measure for employment compensation is Wages, which is the corporation's total salaries and wages, given in logarithms. Model 1 and 3 include all the base corporate-level financial variables in addition to macro-economic variables. In Models 2 and 4 we include, in addition to basic investment and employment compensation determinants, lagged values of alternative investment measures and other corporate and industry controls. The variable LTRO-Country Uptake is equal to zero until Q4-2011, and is equal to the country's total LTRO uptake amount, scaled by the country's central government debt, afterwards. The sample period is $2002-2014$, based on quarterly observations. (*** denotes significance at the $1 \%$ level, ${ }^{* *}$ significance at the $5 \%$ level, and $*$ significance at the $10 \%$ level. The numbers in parentheses are standard errors.) 
Table 6

Counter-factual analysis of the LTRO effect and country risk

\begin{tabular}{|c|c|c|c|}
\hline \multicolumn{4}{|l|}{ Panel A: Cash Holdings } \\
\hline & Cash & \multicolumn{2}{|c|}{ Cash } \\
\hline & $\begin{array}{c}\text { Full sample } \\
(1)\end{array}$ & $\begin{array}{c}\text { High-Risk Sovereign } \\
(2)\end{array}$ & $\begin{array}{c}\text { Low-Risk Sovereign } \\
\text { (3) }\end{array}$ \\
\hline Post-LTRO & $\begin{array}{c}0.414^{* *} \\
(0.20)\end{array}$ & $\begin{array}{l}0.047 \\
(0.34)\end{array}$ & $\begin{array}{c}0.965 * * * \\
(0.27)\end{array}$ \\
\hline Post-LTRO x Non-Eurozone & $-0.969 * * *$ & 0.020 & $-1.050^{* * *}$ \\
\hline & $(0.11)$ & $(0.21)$ & $(0.15)$ \\
\hline$R$-square & 0.751 & 0.677 & 0.762 \\
\hline$N$ & 143731 & 35385 & 103686 \\
\hline \multicolumn{4}{|l|}{ Panel B: Debt Financing } \\
\hline & Leverage & \multicolumn{2}{|c|}{$\begin{array}{ll}\text { Leverage } \\
\end{array}$} \\
\hline & $\begin{array}{c}\text { Full sample } \\
(1)\end{array}$ & $\begin{array}{l}\text { High-Risk Sovereign } \\
(2)\end{array}$ & $\begin{array}{c}\text { Low-Risk Sovereign } \\
\text { (3) }\end{array}$ \\
\hline Post-LTRO & $\begin{array}{c}0.722^{* * *} \\
(0.21)\end{array}$ & $\begin{array}{c}1.056^{* *} \\
(0.42)\end{array}$ & $\begin{array}{c}-0.134 \\
(0.28)\end{array}$ \\
\hline Post-LTRO x Non-Eurozone & $-0.964^{* * *}$ & $-1.141^{* * *}$ & $-1.099 * * *$ \\
\hline & $(0.12)$ & $(0.26)$ & $(0.16)$ \\
\hline$R$-square & 0.586 & 0.525 & 0.617 \\
\hline$N$ & 149798 & 37088 & 107834 \\
\hline \multicolumn{4}{|l|}{ Panel C: Investments } \\
\hline & Investments & \multicolumn{2}{|c|}{ Investments } \\
\hline & $\begin{array}{l}\text { Full sample } \\
(1)\end{array}$ & $\begin{array}{c}\text { High-Risk Sovereign } \\
(2)\end{array}$ & $\begin{array}{c}\text { Low-Risk Sovereign } \\
\text { (3) }\end{array}$ \\
\hline Post-LTRO & $\begin{array}{c}-0.368^{* * *} \\
(0.08)\end{array}$ & $\begin{array}{c}-0.420^{* *} \\
(0.18)\end{array}$ & $\begin{array}{c}-0.627^{* * *} \\
(0.10)\end{array}$ \\
\hline Post-LTRO x Non-Eurozone & $-0.519^{* * *}$ & $-0.979 * * *$ & $-0.408^{* * *}$ \\
\hline & $(0.05)$ & $(0.11)$ & $(0.06)$ \\
\hline$R$-square & 0.586 & 0.525 & 0.617 \\
\hline$N$ & 149798 & 37088 & 107834 \\
\hline \multicolumn{4}{|l|}{ Panel D: Employment } \\
\hline & Wages & \multicolumn{2}{|c|}{ Wages } \\
\hline & $\begin{array}{l}\text { Full sample } \\
\text { (1) }\end{array}$ & $\begin{array}{l}\text { High-Risk Sovereign } \\
(2)\end{array}$ & $\begin{array}{c}\text { Low-Risk Sovereign } \\
\text { (3) }\end{array}$ \\
\hline Post-LTRO & $\begin{array}{c}-0.094^{* *} \\
(0.04)\end{array}$ & $\begin{array}{c}-0.079 \\
(0.05)\end{array}$ & $\begin{array}{c}-0.176^{* * *} \\
(0.05)\end{array}$ \\
\hline Post-LTRO x Non-Eurozone & $-0.068^{* * *}$ & $-0.088^{* *}$ & $-0.153^{* * *}$ \\
\hline & $(0.02)$ & $(0.03)$ & $(0.02)$ \\
\hline$R$-square & 0.772 & 0.832 & 0.769 \\
\hline$N$ & 91049 & 19222 & 69184 \\
\hline
\end{tabular}

This table presents estimates of the "counterfactual" effect of the liquidity uptake from the ECB's three-year Longer-term Refinancing Operations (LTROs), on corporate policies, in a sample of corporations located in the European Union (EU), both either inside or outside the Eurozone. The variable Post-LTRO is a dummy variable equal to 1, for year-quarter observations after the ECB had implemented the first three-year LTRO intervention (Q4-2011). The variable Post-LTRO x Non-Eurozone is the interaction variable between the non-Eurozone dummies and LTRO intervention and captures, accordingly, the effect of the liquidity intervention on corporate policies in non-LTRO countries ("counterfactual" effect) accordingly, equal to 1, for non-Eurozone corporations after the first LTRO intervention (for details see Appendix B2). In Model 1, we use the full sample of corporations. In Models 2 and 3, corporations are separated into high and low-risk sovereigns, based on their location and the respective country's CDS spreads. High (Low) Sovereign Risk is defined as a CDS spread above (below) the median in the pre-intervention and crisis period (2009 and 2010). In Panels A to Panels D we present the estimates from our analysis of corporate cash holdings, leverage, investment, and wages, respectively. The sample period is 2002-2014, based on quarterly observations. In all specifications, we use controls as well as firm and time fixed effects. (*** denotes significance at the $1 \%$ level, ** significance at the $5 \%$ level, and $*$ significance at the $10 \%$ level. The numbers in parentheses are standard errors.) 
Table 7

Bank debt reliance and LTRO uptake effect on corporate policies

\begin{tabular}{|c|c|c|c|c|}
\hline & \multicolumn{2}{|c|}{ Investments } & \multicolumn{2}{|c|}{ Wages } \\
\hline & $\begin{array}{c}\text { High Bank Debt } \\
(1)\end{array}$ & $\begin{array}{c}\text { Low Bank Debt } \\
(2)\end{array}$ & $\begin{array}{c}\text { High Bank Debt } \\
(3)\end{array}$ & $\begin{array}{c}\text { Low Bank Debt } \\
(4)\end{array}$ \\
\hline LTRO-Country Uptake & $\begin{array}{c}-1.286^{* * *} \\
(0.37)\end{array}$ & $\begin{array}{c}-1.123^{* * *} \\
(0.33)\end{array}$ & $\begin{array}{c}-0.023 \\
(0.10)\end{array}$ & $\begin{array}{c}-0.199 \\
(0.15)\end{array}$ \\
\hline Cash Flow & $\begin{array}{c}0.015^{* * *} \\
(0.00)\end{array}$ & $\begin{array}{c}0.007^{* * *} \\
(0.00)\end{array}$ & $\begin{array}{c}-0.006^{* * *} \\
(0.00)\end{array}$ & $\begin{array}{c}-0.004^{* * *} \\
(0.00)\end{array}$ \\
\hline Market-to-Book & $\begin{array}{c}0.007^{* * *} \\
(0.00)\end{array}$ & $\begin{array}{c}0.004^{* * *} \\
(0.00)\end{array}$ & $\begin{array}{l}0.000 \\
(0.00)\end{array}$ & $\begin{array}{c}0.000^{* * *} \\
(0.00)\end{array}$ \\
\hline Size & $\begin{array}{c}0.184^{* * *} \\
(0.06)\end{array}$ & $\begin{array}{c}0.087^{* *} \\
(0.04)\end{array}$ & $\begin{array}{c}0.712^{* * *} \\
(0.02)\end{array}$ & $\begin{array}{c}0.668^{* * *} \\
(0.02)\end{array}$ \\
\hline Leverage & $\begin{array}{c}-0.019 * * * \\
(0.00)\end{array}$ & $\begin{array}{c}-0.013^{* * *} \\
(0.00)\end{array}$ & $\begin{array}{c}-0.001 \\
(0.00)\end{array}$ & $\begin{array}{c}-0.000 \\
(0.00)\end{array}$ \\
\hline Rated & $\begin{array}{c}0.615^{* *} \\
(0.30)\end{array}$ & $\begin{array}{l}0.152 \\
(0.12)\end{array}$ & $\begin{array}{l}0.171 \\
(0.10)\end{array}$ & $\begin{array}{l}0.071 \\
(0.07)\end{array}$ \\
\hline Sovereign CDS & $\begin{array}{c}-0.689^{* * *} \\
(0.16)\end{array}$ & $\begin{array}{c}-0.620^{* * *} \\
(0.13)\end{array}$ & $\begin{array}{c}-0.145^{* *} \\
(0.06)\end{array}$ & $\begin{array}{c}-0.055 \\
(0.07)\end{array}$ \\
\hline Sovereign Export & $\begin{array}{c}-0.012 \\
(0.01)\end{array}$ & $\begin{array}{c}-0.020 * * * \\
(0.00)\end{array}$ & $\begin{array}{c}-0.003 \\
(0.00)\end{array}$ & $\begin{array}{c}0.006^{*} \\
(0.00)\end{array}$ \\
\hline Time fixed effects & Yes & Yes & Yes & Yes \\
\hline Firm fixed effects & Yes & Yes & Yes & Yes \\
\hline$R$-square & 0.524 & 0.563 & 0.779 & 0.789 \\
\hline$N$ & 31262 & 45556 & 20201 & 28804 \\
\hline
\end{tabular}

This table presents estimates of the effect of the corporate reliance on bank debt and the liquidity uptake from the ECB's three-year Longer-term Refinancing Operations (LTROs), on corporate policies, in a sample of corporations located in the Eurozone. Bank Debt is the debt from bank loans, divided by total assets. In Models 1 and 2, and Models 3 and 4 corporations are separated into those with High and Low Bank Debt ratios, based upon their bank debt ratios one year before the first threeyear LTRO intervention (Q4-2010). In Models 1 and 2, we analyze the impact on corporate investments (capital expenditure scaled by total assets), and in Models 3 and 4, wages (salaries on the logarithmic scale). The variable LTRO-Country Uptake is equal to zero until Q4-2011, and equal to the country-specific total LTRO uptake amount, scaled by the central government debt of the country, thereafter. The sample period is 2002-2014, based on quarterly observations. (*** denotes significance at the $1 \%$ level, ${ }^{*}$ significance at the $5 \%$ level, and $*$ significance at the $10 \%$ level. The numbers in parentheses are standard errors.) 
Table 8

LTRO uptake by lenders and investment policies

\begin{tabular}{lcc}
\hline \hline & Investments & Wages \\
\cline { 2 - 3 } & $(1)$ & $(2)$ \\
\hline & & 0.020 \\
LTRO-Bank Uptake & $-0.532^{* * *}$ & $(0.05)$ \\
Cash Flow & $(0.11)$ & $-0.003^{*}$ \\
& $0.018^{* * *}$ & $(0.00)$ \\
Market-to-Book & $(0.00)$ & $0.001^{* * *}$ \\
Size & $0.003^{* * *}$ & $(0.00)$ \\
& $(0.00)$ & $0.715^{* * *}$ \\
Leverage & 0.008 & $(0.03)$ \\
& $(0.04)$ & $-0.003^{* *}$ \\
Rated & $-0.023^{* * *}$ & $(0.00)$ \\
Sovereign CDS & $(0.00)$ & $-0.173^{* *}$ \\
Sovereign Export & $0.548^{* * *}$ & $(0.08)$ \\
& $(0.12)$ & 0.054 \\
Time fixed effects & $-0.740^{* * *}$ & $(0.13)$ \\
Firm fixed effects & $(0.19)$ & 0.001 \\
$R$-square & $-0.029^{* * *}$ & $(0.00)$ \\
$N$ & $(0.00)$ & Yes \\
\hline \hline
\end{tabular}

This table presents estimates of the effect of the liquidity uptake from the ECB's three-year Longer-term Refinancing Operations (LTROs) by loan-related banks on investment polices in a subsample of Eurozone corporations with existing loan information in LPC Dealscan. The variable LTRO-Bank Uptake is equal to zero until Q4-2011, and equal to the LTRO uptake amount of the corporate's related banks, scaled by the size of each bank, thereafter. We classify Eurozone banks as related if the corporation in the five years prior to the first LTRO intervention had a loan relation to the bank. The information about the bank-specific LTRO uptake is based upon hand-collected data from Bloomberg, as well as central bank announcements and public commentaries. The loan information data is obtained from LPC Dealscan. The sample period is 2002-2014, and based on quarterly observations. (*** denotes significance at the $1 \%$ level, $* *$ significance at the $5 \%$ level, and $*$ significance at the $10 \%$ level. The numbers in parentheses are standard errors.) 
Table 9

LTRO uptake of lenders and LTRO repayment

\begin{tabular}{|c|c|c|c|c|c|c|}
\hline \multicolumn{7}{|c|}{ Panel A: Low Early LTRO Repayment } \\
\hline & Cash & Leverage & Net Debt & Short-term Debt & Investments & Wages \\
\hline & $(1)$ & $(2)$ & $(3)$ & $(4)$ & $(5)$ & $(6)$ \\
\hline \multirow[t]{2}{*}{ LTRO-Bank Uptake } & $8.194^{* * *}$ & $19.685^{* * *}$ & $17.435^{* * *}$ & 0.024 & -0.695 & -0.097 \\
\hline & $(1.82)$ & $(3.01)$ & $(3.78)$ & $(0.01)$ & $(1.06)$ & $(0.26)$ \\
\hline$R$-square & 0.634 & 0.739 & 0.739 & 0.809 & 0.544 & 0.834 \\
\hline$N$ & 4845 & 4845 & 4053 & 3867 & 5116 & 2988 \\
\hline
\end{tabular}

Panel B: Medium Early LTRO Repayment

\begin{tabular}{|c|c|c|c|c|c|c|}
\hline & $\begin{array}{c}\text { Cash } \\
(1)\end{array}$ & $\frac{\text { Leverage }}{(2)}$ & $\frac{\text { Net Debt }}{(3)}$ & $\frac{\text { Short-term Debt }}{(4)}$ & $\frac{\text { Investments }}{(5)}$ & $\frac{\text { Wages }}{(6)}$ \\
\hline LTRO-Bank Uptake & $\begin{array}{c}-0.908^{* * *} \\
(0.22)\end{array}$ & $\begin{array}{c}-0.536 \\
(0.33)\end{array}$ & $\begin{array}{l}0.194 \\
(0.45)\end{array}$ & $\begin{array}{c}-0.012^{* * *} \\
(0.00)\end{array}$ & $\begin{array}{c}-0.528^{* * *} \\
(0.11)\end{array}$ & $\begin{array}{l}0.007 \\
(0.06)\end{array}$ \\
\hline$R$-square & 0.768 & 0.777 & 0.810 & 0.791 & 0.640 & 0.681 \\
\hline$N$ & 17032 & 17032 & 13573 & 12828 & 17883 & 11246 \\
\hline
\end{tabular}

Panel C: High Early LTRO Repayment

\begin{tabular}{|c|c|c|c|c|c|c|}
\hline & $\frac{\text { Cash }}{(1)}$ & $\frac{\text { Leverage }}{(2)}$ & $\frac{\text { Net Debt }}{(3)}$ & Short-term Debt & $\begin{array}{c}\text { Investments } \\
(5)\end{array}$ & $\frac{\text { Wages }}{(6)}$ \\
\hline LTRO-Bank Uptake & $\begin{array}{c}15.915 \\
(9.96)\end{array}$ & $\begin{array}{c}-11.308 \\
(11.4)\end{array}$ & $\begin{array}{c}-8.542 \\
(14.3)\end{array}$ & $\begin{array}{c}-0.121 \\
(0.07)\end{array}$ & $\begin{array}{c}9.938^{* *} \\
(3.95)\end{array}$ & $\begin{array}{l}1.398 \\
(2.07)\end{array}$ \\
\hline$R$-square & 0.717 & 0.766 & 0.783 & 0.737 & 0.572 & 0.774 \\
\hline$N$ & 9116 & 9116 & 7675 & 6931 & 9506 & 5433 \\
\hline
\end{tabular}

This table presents estimates of the effect of the liquidity uptake from the ECB's three-year Longer-term Refinancing Operations (LTROs) by loan-related banks, and LTRO repayment policies on corporate polices, in a subsample of Eurozone corporations with existing loan information in LPC Dealscan. The variable LTRO-Bank Uptake is equal to zero until Q4-2011, and equal to the LTRO uptake amount of the corporate's related banks, scaled by the size of each bank, thereafter. In Panels A through Panels C corporations are separated based on their location and the respective country's LTRO repayment policy, compared to the initial LTRO-country uptake. Low (Medium, High) Early LTRO Repayment is defined as a LTRO repayment ratio from 2012 to 2013 , i.e., at the first possible LTRO repayment date, that is below $30 \%$ (between $30 \%$ and $70 \%$, above $70 \%$ ). The sample period is 2002-2014, and based on quarterly observations. (*** denotes significance at the $1 \%$ level, ${ }^{* *}$ significance at the $5 \%$ level, and * significance at the $10 \%$ level. The numbers in parentheses are standard errors.) 
Table 10

Fiscal Policy and LTRO uptake effect on investment policies

\begin{tabular}{|c|c|c|c|c|c|}
\hline \multicolumn{6}{|c|}{ Panel A: Eurozone Sample } \\
\hline & \multicolumn{3}{|c|}{ Investments } & \multicolumn{2}{|c|}{ Investments } \\
\hline & Increased & Unchanged & Decreased & Increased & Decreased \\
\hline & $\begin{array}{l}\text { Corp. Tax } \\
\text { (1) }\end{array}$ & $\begin{array}{c}\text { Corp. Tax } \\
\text { (2) }\end{array}$ & $\begin{array}{c}\text { Corp. Tax } \\
\text { (3) }\end{array}$ & $\begin{array}{c}\text { Gov. Investment } \\
\text { (4) }\end{array}$ & $\begin{array}{c}\text { Gov. Investment } \\
\text { (5) }\end{array}$ \\
\hline \multirow[t]{2}{*}{ LTRO-Country Uptake } & $-8.425^{* * *}$ & $-1.630 * * *$ & $25.052^{* *}$ & $2.249 * * *$ & $-1.825^{* * *}$ \\
\hline & $(1.31)$ & $(0.31)$ & $(9.80)$ & $(0.70)$ & $(0.29)$ \\
\hline$R$-square & 0.626 & 0.555 & 0.530 & 0.576 & 0.563 \\
\hline$N$ & 25389 & 43192 & 15934 & 39090 & 45425 \\
\hline
\end{tabular}

Panel B: Eurozone Sample with existing loan information

\begin{tabular}{|c|c|c|c|c|c|}
\hline & \multicolumn{3}{|c|}{ Investments } & \multicolumn{2}{|c|}{ Investments } \\
\hline & $\begin{array}{l}\text { Increased } \\
\text { Corp. Tax } \\
\text { (1) }\end{array}$ & $\begin{array}{l}\text { Unchanged } \\
\text { Corp. Tax } \\
\text { (2) }\end{array}$ & $\begin{array}{l}\text { Decreased } \\
\text { Corp. Tax } \\
\quad(3)\end{array}$ & $\begin{array}{c}\text { Increased } \\
\text { Gov. Investment } \\
(4)\end{array}$ & $\begin{array}{c}\text { Decreased } \\
\text { Gov. Investment } \\
(5)\end{array}$ \\
\hline LTRO-Bank Uptake & $\begin{array}{l}0.182 \\
(0.16)\end{array}$ & $\begin{array}{c}-1.039 * * * \\
(0.16)\end{array}$ & $\begin{array}{c}7.916^{*} \\
(4.38)\end{array}$ & $\begin{array}{c}-0.402^{* * *} \\
(0.14)\end{array}$ & $\begin{array}{c}-0.495^{* *} \\
(0.24)\end{array}$ \\
\hline $\begin{array}{l}R \text {-square } \\
N\end{array}$ & $\begin{array}{c}0.665 \\
9013\end{array}$ & $\begin{array}{l}0.578 \\
17486\end{array}$ & $\begin{array}{c}0.609 \\
6006\end{array}$ & $\begin{array}{l}0.608 \\
13897\end{array}$ & $\begin{array}{l}0.605 \\
18608\end{array}$ \\
\hline
\end{tabular}

This table presents estimates of the effect of fiscal policy and the liquidity uptake from the ECB's three-year Longer-term Refinancing Operations (LTROs) on corporate investment. Our measure for the corporations investment is Capital Expenditure, which is the corporate capital expenditure scaled by total assets. Panel A shows the results based upon a sample of corporations located in the Eurozone and using the country-specific LTRO uptake. The variable LTRO-country Uptake is equal to zero until Q4-2011, and equal to the country-specific total LTRO uptake amount, scaled by the central government debt of the country, thereafter. Panel B shows the results based upon a subsample of Eurozone corporations with existing loan information in LPC Dealscan, and using the lender specific LTRO uptake. The variable LTRO-Bank Uptake is equal to zero until Q4-2011, and equal to the LTRO uptake amount of the corporate's related banks, scaled by the size of each bank, thereafter. In Models 1, 2 and 3, corporations are separated into those with increased, unchanged and decreased corporate tax rates (Increased (Unchanged/Decreased) Corporate Tax, based on the home countries' (absolut) change of the corporate tax rate between 2010-Q4 and 2012-Q4, i.e., around the first LTRO. The corporate tax rate data is given on a quarterly basis. In Models 4 and 5, corporations are separated into those with increased and decreased government investment (Increased (Decreased) Government Investment), based on the home countries' (relative) change in the government investment expenditures to GDP ratio between 2010-Q4 and 2012-Q4, i.e., around the first LTRO. The sample period is 2002-2014, based on quarterly observations. (*** denotes significance at the $1 \%$ level, ${ }^{* *}$ significance at the $5 \%$ level, and $*$ significance at the $10 \%$ level. The numbers in parentheses are standard errors.) 
Appendices 


\section{Note A1 - Background on ECB's open market operations}

The operational framework of the ECB consists of open market operations, standing facilities, minimum reserve, and non-standard monetary policy measures. In particular, ECB open market operations are aimed "to steer short-term interest rates, to manage the liquidity situation and to signal the monetary policy stance in the euro area". We can classify the ECB open market operations into regular open market operations and non-standard monetary policies. ${ }^{32}$

The regular open market operations consist of main refinancing operations (MROs) and three-month longer-term refinancing operations (three-month LTROs). MROs refer the regular one-week liquidity providing reverse transactions, which are the ECB's primary, regular open market operations. In October 2008, the ECB switched to a fixed-rate full allotment mode such that Eurozone banks then were able to obtain unlimited short-term liquidity at a fixed rate, provided they pledged sufficient eligible collateral. To provide additional, longer-term refinancing to the financial sector, ECB also implemented three-month LTROs, which were substantial in size. In 2003, refinancing via LTROs amounted to 45 billion Euro, referring to about $20 \%$ of the overall liquidity provided by the ECB. In recent years, the regular open market operations are complemented by a set of non-standard monetary policies. On 28 March 2008, six-month LTROs are announced, while the regular 3-month LTROs remained unaffected. The six-month LTRO came in two rounds (allotted on 2 April and 9 July 2008), and both were present with an amount of 25 billion Euro. The threeand six-month LTROs were carried out through a variable-rate standard tender procedure. In June 2010, the ECB Governing Council decided to adopt a fixed-rate tender procedure with full allotment in the regular three-month LTROs, to be allotted on 28 July, 25 August, and 29 September 2010. On 6 October 2011, two twelve-month LTROs were announced. The operations were introduced as fixed-rate tender procedures with full allotment, and were conducted in addition to the regular and special term refinancing operations in October and December 2011, respectively.

On 8 December 2011, to increase the ECB's support for the Eurozone banking sector and to improve the real economy, two three-year LTROs were announced, with the option of early repayment after one year. Moreover, it was stated, "there is no limit on what the banks can do with the money". ${ }^{33}$ The LTROs were allotted on December 21, 2011 (LTRO I) and February 29, 2012 (LTRO II), respectively. The loans were settled one day after the allotment, on December 22, 2011 and March 1, 2012, respectively, with maturities January 29, 2015 and February 26, 2015, respectively. The interest rate on the two long-term loans was the average MRO rate over the life of the operation, which was very low at approximately $1 \%$. The three-year LTROs eased credit conditions, not only by allowing banks to borrow unlimited funds for three years (given the provision of eligible collateral) but also by assisting banks with the management of their "gap risk", i.e., increasing banks' ability to match the tenor of their assets and liabilities. Prior to the LTROs, many banks were only able to secure overnight funding.

To increase the attractiveness of the unconventional LTROs, participating banks were given the option to repay part or full amount of their borrowings after one year without any penalty. Under this arrangement, the first three-year LTRO (LTRO I) could be repaid as of 25 January 2013, and the second (LTRO II) as of 22 February 2013. Banks used the two LTROs loans to both rollover previous central bank borrowing and obtain new borrowing. In total, 523 credit institutions participated in the first LTRO, and were provided with 489.2 billion Euro, which amounted to a net injection of 210 billion Euro ${ }^{34}$. As outlined by FitchRatings (2012), the participants in the first LTRO round can roughly be divided into two groups. On the one hand, banks from the periphery countries were highly active due to their actual capital needs, as the LTROs provided them with the only option for accessing medium-term funding. However, for many banks/countries, participating in the unconventional LTROs simply provided an opportunity for them to replace shorter-term funds with $1 \%$ three-year borrowing. As outlined by the ECB, 45.72 billion Euro of the total uptake was used to replace the 12-month allotment that had taken place in October 2011. ${ }^{35}$ Specifically, a total of 123 counter-parties

\footnotetext{
${ }^{32}$ Financial instruments that can be used to achieve the open market transactions include reverse transaction, outright transactions, issuance of debt certificates, foreign exchange swaps, and collection of fixed term deposits. For details, see https://www.ecb.europa.eu/mopo/implement/html/index.en.html.

${ }^{33}$ Source: http://www.nytimes.com/2011/12/22/business/a-central-bank-doing-what-central-banks-do.html?_r=0.

${ }^{34}$ This amount is the injection net of other operations conducted in the same weeks (such as three-month operations and regular weekly operations) and operations maturing on these dates.

${ }^{35}$ Source: ECB Monthly Bulletin, January 2012.
} 
chose this option, many of which were located in highly rated, safe countries such as France and Germany, which took up a significant share. In particular, the ECB outlines that the banks that placed the highest bids were those that (1) had the highest upcoming rollover needs and (2) had the lowest maturity structures (average tenor). On the other hand, it was also claimed that certain banks had avoided the LTROs due to concerns that participating banks would be stigmatized as troubled institutions. ${ }^{36}$

Since a considerable portion of the banks' collateral was already pledged at the ECB at the time of the first allotment, the central banks relaxed the collateral requirements to encourage the LTRO uptake in the second round. For instance, the rating threshold was reduced for certain asset-backed securities (ABS), and rated corporate loans were allowed to be used as collateral, as long as they were processed through national central banks and an appropriate haircut was taken. The second round of the LTROs provided a liquidity injection of 529.5 billion Euro (310 billion Euro in net terms) to 800 credit institutions. Table 1 provides the LTRO uptake numbers by country.

In June 2014, to "further ease private sector credit conditions and stimulate bank lending to the real economy", ECB announced targeted LTROs (TLTROs) which provide financing to credit institutions with maturity up to four years. Under the TLTRO, counter-parties are only allowed to borrow an amount that is capped in accordance with their lending to the corporate sector. In September and December 2014, the ECB initially introduced two successive TLTROs, in which counter-parties were able to borrow in accordance with their initial allowance, at a rate equal to a 10 basis point spread over the MRO rate. In January 2015, and applying to the series of four rounds of TLTRO conducted between March 2015 and June 2016, the ECB eliminated this excess MRO spread. The TLTROs will all mature on September 26, 2018, while the dates for voluntary early repayment depend on the actual settlement dates.

In addition to the MROs, LTROs and TLTROs, several outright asset purchase programmes (APP) have been implemented since 2009. Under expanded APP, ECB purchases marketable debt instruments from both public and private sector to inject liquidity into the banking system, with monthly purchase target of 80 billion euros. ${ }^{37}$ The active APP consists of the third covered bond purchase programme (CBPP3), asset-backed securities purchase programme (ABSPP), and public sector purchase program (PSPP). The starting dates for CBPP3, ABSPP, and PSPP are 20 October 2014, 21 November 2014, and 9 March 2015, respectively. These programs are intended to be carried out "until the end of March 2017 and in any case until the Governing Council sees a sustained adjustment in the path of inflation that is consistent with its aim of achieving inflation rates below, but close to, $2 \%$ over the medium term."

Besides the active APP, there are several terminated APP programs in the past years, including first covered bond purchase program (CBPP), second covered bond purchase program (CBPP2), and securities markets programs (SMP). CBPP was launched on 2 July 2009, and ended on 30 June 2010 when it reached a nominal amount of 60 billion euro. CBPP2 was launched in November 2011, and ended on 31 October 2012 with a nominal amount of 16.4 billion euro. SMP was started on 10 May 2010 with the aim of "addressing the severe tensions in certain market segments which had been hampering the monetary policy transmission mechanism". The SMP focused on liquidity provision in the secondary sovereign bond markets in particular countries. However, following an ECB decision on 6 September 2012, SMP was terminated, and outright monetary transactions (OMT) was introduced. OMT will be considered by the ECB once a Eurozone government asks for financial assistance. Therefore, OMT is attached to the bailout program of European Financial Stability Facility or European Stability Mechanism. ${ }^{38}$

\footnotetext{
${ }^{36}$ See, for instance, http://www.zerohedge.com/contributed/ltro-users-manual.

${ }^{37}$ This number was 60 billion euros from March 2015 until March 2016.

${ }^{38}$ European Stability Mechanism (ESM) is a permanent bailout funding program introduced in 2012, replacing the previous temporary European Financial Stability Facility (EFSF) and European Financial Stabilization Mechanism.
} 


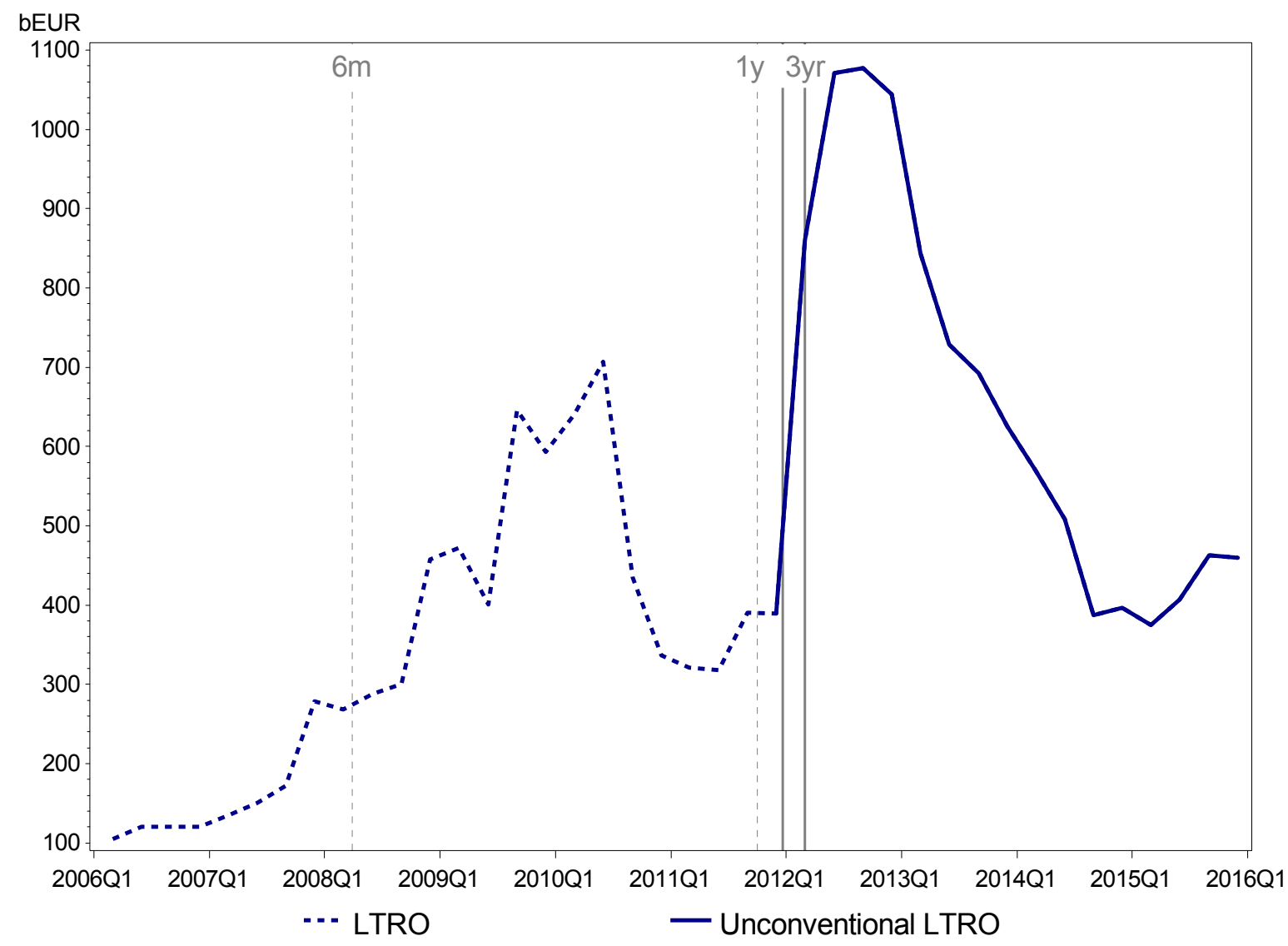

Figure A1

Time series of the ECB's Longer-term Refinancing Operations

This figure plots the amounts of the ECB's Longer-Term Refinancing Operations (LTROs). The numbers are given in billions of Euros. Unconventional LTROs refers to the two three-year LTROs. The data source is the ECB Statistical Warehouse, which publishes monthly numbers for the outstanding amounts. 


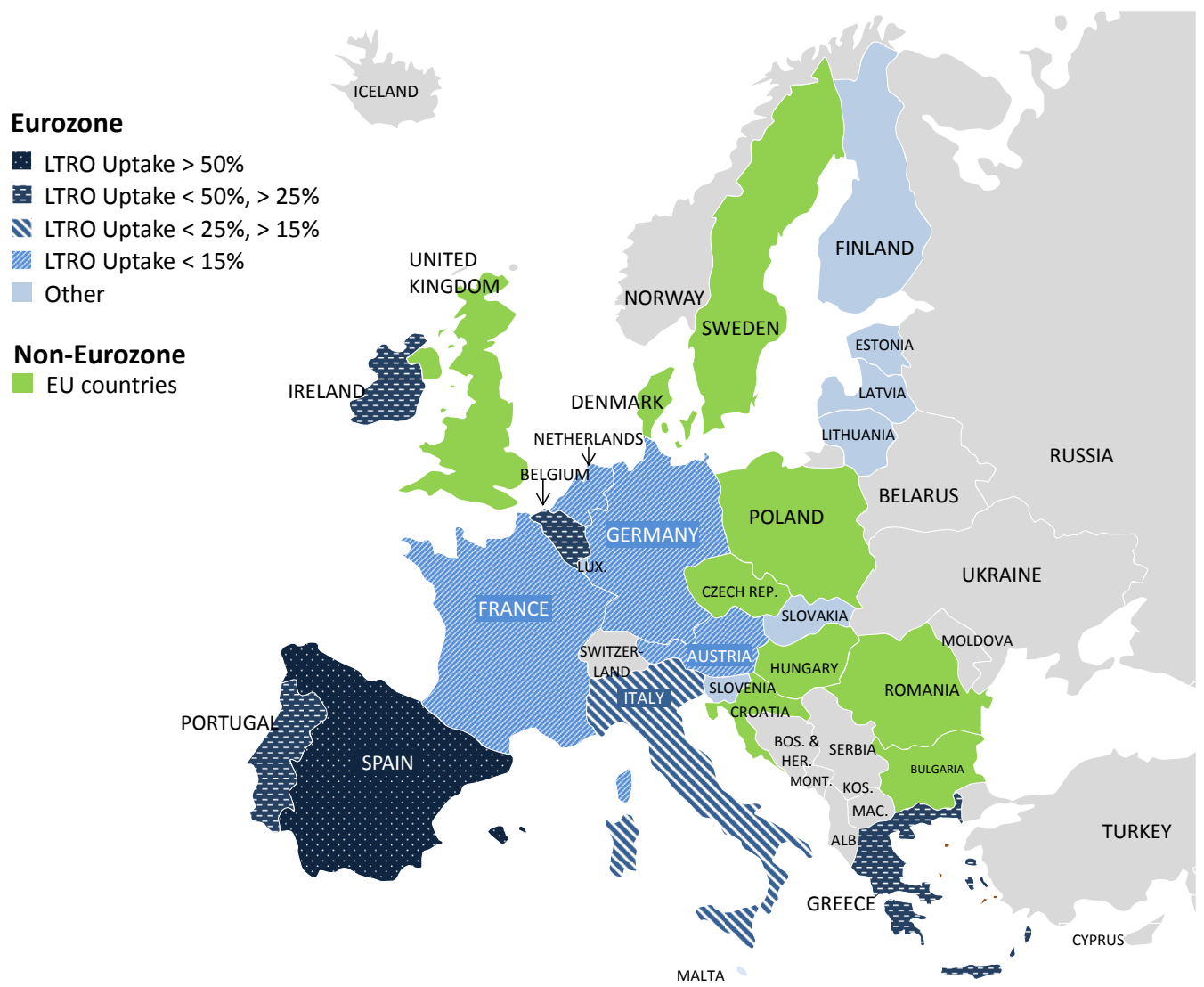

Figure A2

LTRO uptake in the Eurozone

This figure presents the total liquidity injection that countries within the Eurozone obtained from the three-year Longer-term Refinancing Operations (LTROs), which were initiated by the European Central Bank (ECB) on December 21, 2011 (LTRO I) and February 29, 2012 (LTRO II), respectively. The color scaling refers to the respective countries' total LTRO uptake, scaled by the central government debt. The information about the country-specific LTRO uptake is based upon hand-collected data from Bloomberg as well as central bank announcements and public commentaries. The information on central government debt by country is obtained from the World Bank Database. In the case of Greece, we only have information about the total LTRO amount that, besides the three-year LTROs, also includes the standard one-month and three-month LTROs. As we cannot separate the latter out, the number is not directly comparable to the uptake numbers for other countries. 


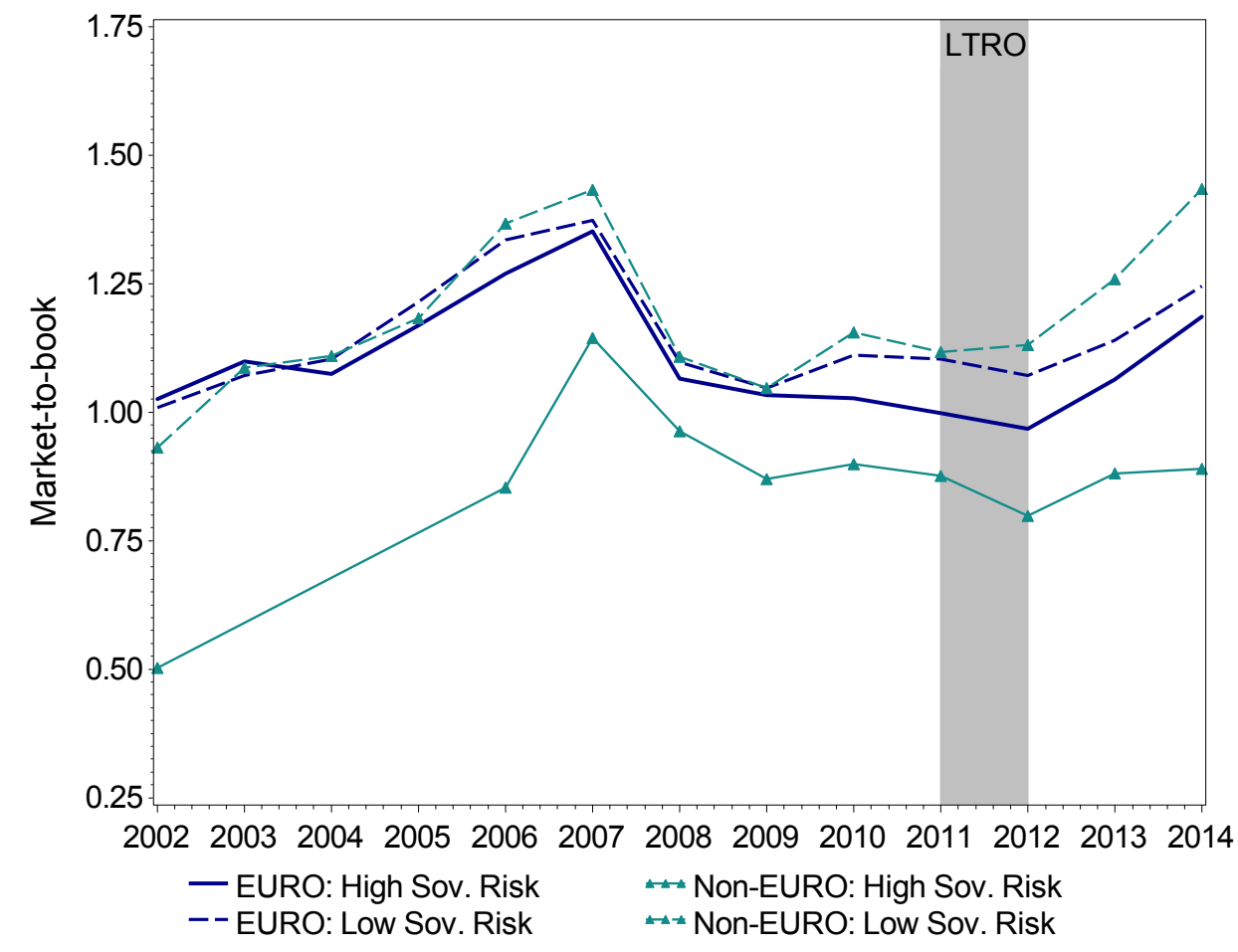

Figure A3

Time series of the corporations' market-to-book ratios and the LTRO announcement and implementation

This figure presents the corporations' average (median) market-to-book ratios as a proxy for the stock market reaction to the ECB's interventions. The market-to-book is measured by the ratio of corporations' market value of equity to the book value of equity, and presented on a yearly basis. The yearly measure is the median of quarterly observations. The time series are conducted for low and high-sovereign-risk countries, as well as Eurozone (EURO) and non-Eurozone (non-EURO) countries, respectively. The subsamples of high and low-sovereign-risk countries are based upon the countries CDS spreads two years before the LTRO intervention. 
Table A1

Sample countries

\begin{tabular}{|c|c|c|c|c|c|}
\hline \multicolumn{6}{|c|}{ Panel A: Eurozone } \\
\hline Country & Country Code & EU Membership & Euro Adoption & Region & Credit Rating (2011) \\
\hline Austria & AUT & 1995 & 1999 & Core & $\mathrm{AAA}$ \\
\hline Belgium & BEL & 1995 & 1999 & Core & $\mathrm{AA}$ \\
\hline Finland & FIN & 1995 & 1999 & Core & AAA \\
\hline France & FRA & 1995 & 1999 & Core & A \\
\hline Germany & DEU & 1995 & 1999 & Core & AAA \\
\hline Greece & GRC & 1995 & 2001 & Periphery & $\mathrm{CCC}$ \\
\hline Ireland & IRL & 1995 & 1999 & Periphery & BB \\
\hline Italy & ITA & 1995 & 1999 & Periphery & BB \\
\hline Netherlands & NLD & 1995 & 1999 & Core & AAA \\
\hline Portugal & PRT & 1995 & 1999 & Periphery & B \\
\hline Spain & ESP & 1995 & 1999 & Periphery & $\mathrm{BB}$ \\
\hline
\end{tabular}

Panel B: Non-Eurozone

\begin{tabular}{|c|c|c|c|c|c|}
\hline Country & Country Code & EU Membership & Euro Adoption & Region & Credit Rating (2011) \\
\hline Bulgaria & BGR & 2007 & & Periphery & $\mathrm{A}$ \\
\hline Czech Republic & $\mathrm{CZE}$ & 2004 & & Periphery & AA \\
\hline Denmark & DNK & 1995 & & Core & AAA \\
\hline Hungary & HUN & 2004 & & Periphery & B \\
\hline Lithuania & LTU & 2004 & 2015 & Periphery & A \\
\hline Latvia & LVA & 2004 & 2014 & Periphery & $\mathrm{A}$ \\
\hline Poland & POL & 2004 & & Periphery & AA \\
\hline Romania & ROU & 2007 & & Periphery & BB \\
\hline Sweden & SWE & 1995 & & Core & AAA \\
\hline United Kingdom & GBR & 1995 & & Core & AAA \\
\hline
\end{tabular}

This table presents details of the European countries included in our sample. Panel A covers the countries in our Eurozone sample, Panel B those in our non-Eurozone sample. The Eurozone sample only includes countries that agreed to use the Euro as a common currency in 1999, and adopted the Euro right from its introduction in January 2001, and for which data are available. The sample, Non-Eurozone, includes countries that are outside the Eurozone but are part of the European Union (EU). Accordingly, our sample of EU corporates is the combination of the Eurozone and non-Eurozone samples. EU Membership shows the year the respective country became a member of the EU. Likewise, Euro Adoption shows the year in which a given country adopted the Euro as its local currency. The Credit Rating is based on information from Markit Data as of end 2011. 
Table A2

Summary statistics for non-Eurozone corporations

\begin{tabular}{lrrrrrrrrrrr}
\hline \hline Country & GBR & SWE & POL & DNK & ROU & BGR & LTU & LVA & HUN & CZE & Total \\
\hline & & & & & & & & & & & \\
Cash & 9.38 & 8.94 & 5.23 & 6.05 & 1.64 & 4.07 & 2.36 & 2.72 & 7.74 & 3.33 & 7.94 \\
Investments & 2.55 & 1.90 & 4.04 & 3.36 & 4.37 & 4.66 & 4.66 & 4.07 & 6.77 & 4.32 & 2.74 \\
Wages & 0.09 & 2.65 & 2.17 & 3.76 & 1.68 & 1.44 & 1.96 & 0.46 & 7.75 & 5.36 & 1.12 \\
Leverage & 13.83 & 14.21 & 14.32 & 22.48 & 0.84 & 26.14 & 27.2 & 14.58 & 14.47 & 13.49 & 14.43 \\
Net Debt & 49.81 & 52.68 & 47.08 & 53.49 & 34.28 & 46.86 & 51.57 & 37.67 & 41.59 & 41.70 & 49.56 \\
Short-term Debt & 0.04 & 0.06 & 0.08 & 0.06 & 0.11 & 0.08 & 0.1 & 0.06 & 0.06 & 0.06 & 0.05 \\
Bank Debt & 11.86 & 12.91 & 12.92 & 17.38 & 15.22 & 19.63 & 23.4 & 17.41 & 23.09 & 7.89 & 12.99 \\
Size & 3.82 & 5.57 & 4.72 & 6.51 & 5.23 & 5.29 & 5.22 & 2.04 & 10.43 & 8.70 & 4.47 \\
Market-to-Book & 133.1 & 146.3 & 118.3 & 120.5 & 85.5 & 98.9 & 91.9 & 70.7 & 108.7 & 93.7 & 129.5 \\
Cash Flow & 3.04 & 2.68 & 2.54 & 4.42 & 6.33 & 6.07 & 5.18 & 4.22 & 5.13 & 4.96 & 3.03 \\
Ind. Sigma & 11.23 & 13.66 & 6.17 & 5.87 & 4.18 & 3.33 & 6.14 & 5.56 & 3.12 & 4.23 & 9.19 \\
NWC & -1.62 & 2.11 & 6.91 & 2.96 & 6.38 & 5.82 & 2.32 & 19.17 & 8.86 & 0.02 & 0.82 \\
R\&D/Sales & 0.00 & 0.00 & 0.00 & 0.00 & 0.00 & 0.00 & 0.00 & 0.00 & 0.00 & 0.00 & 0.00 \\
Acquisition & 0.00 & 0.00 & 0.00 & 0.00 & 0.00 & 0.00 & 0.00 & 0.00 & 0.00 & 0.00 & 0.00 \\
Sov. CDS & 42.11 & 13.66 & 79.50 & 20.08 & 213.09 & 180.56 & 110.20 & 125.86 & 45.50 & 32.00 & 34.14 \\
Sov. Export & 0.27 & 0.46 & 0.39 & 0.51 & 0.33 & 0.52 & 0.56 & 0.43 & 0.75 & 0.63 & 0.30 \\
& & & & & & & & & & \\
\# N & 67801 & 20122 & 17319 & 5980 & 2576 & 1018 & 1317 & 1370 & 797 & 420 & 118720 \\
\# Corp. & 2213 & 574 & 461 & 159 & 78 & 30 & 30 & 30 & 22 & 14 & 3611 \\
\hline \hline
\end{tabular}

This table provides sample averages (medians) of corporate characteristics for each country in our sample of non-Eurozone corporates. Cash is the ratio of cash and short-term investments to total assets. Investments is the ratio of capital expenditure to total assets. Wages is the total salaries and wages, given in logarithms. Leverage is the book value of the long-term debt plus debt in current liabilities, divided by total assets. Net Debt is the ratio of current plus non-current liabilities minus cash holdings to total assets. Short-term Debt is the ratio of current liabilities to total assets. Bank Debt is the amount of debt from bank loans, divided by total assets. Size is the total assets, given in logarithms. Market-to-Book is the book value of assets minus the book value of equity plus the market value of equity, all divided by the book value of assets. Cash Flow is the ratio of the cash flow to total assets, where cash flow is the earnings after interest and related expenses, income taxes, and dividends. Industry Sigma is industry cash flow risk, measured by the mean cash flow volatility across two-digit SIC codes. Net Working Capital (NWC) is the difference between current assets and current liabilities net of cash, divided by total assets. RED/Sales is the ratio of R\&D to sales. Acquisition is the ratio of acquisitions to total assets. Sovereign CDS is the five-year sovereign CDS spread for the country. Sovereign Export is the country's export-to-GDP ratio. The sample period for each country is 2002-2014, and the variables are based on quarterly observations. The firm fundamental data are obtained from Compustat Global, while country specific data are obtained from Markit, the World Bank, as well as, the ECB statistics Warehouse. For any data unavailable for a specific quarter, we replace the missing values with the yearly observations. Ratios are given in percentages. 
Table A3

Description of main variables

\begin{tabular}{|c|c|c|}
\hline \multicolumn{2}{|l|}{ Dependent Variables } & \multirow{2}{*}{$\begin{array}{l}\text { Description } \\
\text { Cash is defined as cash including marketable se- } \\
\text { curities. Source: Compustat. }\end{array}$} \\
\hline Cash & $\frac{\operatorname{Cash}_{t}}{\text { Total Assets }}$ & \\
\hline Leverage & $\frac{\operatorname{Debt}_{t}}{\text { Total Assets } t}$ & $\begin{array}{l}\text { Debt is the book value of debt, i.e., the sum of } \\
\text { current and long-term debt. Source: Compustat. }\end{array}$ \\
\hline Net Debt & $\frac{\text { Total liabilities }- \text { Cash }_{t}}{\text { Total Assets }_{t}}$ & $\begin{array}{l}\text { Net debt is current plus non-current liabilities } \\
\text { minus cash holdings. Source: Compustat. }\end{array}$ \\
\hline Short-term Debt & $\frac{\text { Debt due in one year }}{t}$ & Fraction of long-term debt that is due in one year \\
\hline Investments & $\frac{\text { Capital Expenditures }_{t}}{\text { Total Assets }_{t}}$ & Corporate capital spending. Source: Compustat. \\
\hline Wages & $\log (\text { Total Wage payments })_{t}$ & $\begin{array}{l}\text { The natural logarithm of total expenses related } \\
\text { to salaries and wages. Source: Compustat }\end{array}$ \\
\hline \multicolumn{2}{|c|}{ Main Explanatory Variables } & Description \\
\hline Post-LTRO & Dummy & $\begin{array}{l}\text { The variable is equal to } 1 \text { for the post- } \\
\text { intervention period, i.e., Q1-2012 to Q4-2014, } \\
\text { and } 0 \text { otherwise. }\end{array}$ \\
\hline LTRO-Country Uptake & $\frac{\text { Total Country LTRO Uptake }}{t, c}$ & $\begin{array}{l}\text { The total uptake is the sum of the Euro amounts } \\
\text { of the two three-year LTROs (LTRO I and II) for } \\
\text { each country. Accordingly, the variable is equal } \\
\text { to } 0 \text { until time Q4-2011 (first round of three- } \\
\text { year LTRO) and afterwards equal to each coun- } \\
\text { try's total uptake. We scale the total uptake by } \\
\text { the central government debt holdings in the year } \\
\text { 2011. Source: Bloomberg and the World Bank. }\end{array}$ \\
\hline LTRO-Bank Uptake & $\sum_{j=1}^{N_{i}}\left(\frac{\text { Bank LTRO Uptake } t, j}{\text { Bank Size } 2011, j^{\prime}}\right) / N_{i}$ & $\begin{array}{l}\text { The measure is equal to the average of re- } \\
\text { lated banks uptake in the two three-year LTRO } \\
\text { (LTRO I and II) scaled by their respective size. } \\
\text { Accordingly, the variable is equal to } 0 \text { until time } \\
\text { Q4-2011 (first round of three-year LTRO) and } \\
\text { afterwards equal to the average of related banks } \\
\text { total uptake. Source: Bloomberg and annual re- } \\
\text { ports. }\end{array}$ \\
\hline LTRO-Bank Relation & Dummy & $\begin{array}{l}\text { The dummy variable is equal to } 1 \text { for corpora- } \\
\text { tions that in the five years prior to the first LTRO } \\
\text { intervention had a loan relation to a Eurozone } \\
\text { bank that participated in the three-year LTROs } \\
\text { as of December } 2011 \text { and February 2012. Source: } \\
\text { LPC Dealscan. }\end{array}$ \\
\hline Non-Eurozone & Dummy & $\begin{array}{l}\text { Variable equal to } 1 \text { if the company is located in } \\
\text { a country outside the Eurozone, as of } 2014 \text {, and } \\
0 \text { otherwise. See also Appendix A1. }\end{array}$ \\
\hline
\end{tabular}




\begin{tabular}{|c|c|c|}
\hline Other Variables & & Description \\
\hline Size & $\log (\text { Total assets })_{t}$ & Book value of assets. Source: Compustat. \\
\hline Market-to-Book & $\frac{\text { Assets }- \text { Book E. }+ \text { Market E.t }}{\text { Total assets } t}$ & $\begin{array}{l}\text { Book equity is total assets minus total liabilities. } \\
\text { Market equity is the amount of shares outstand- } \\
\text { ing times the share price as of the end of the fiscal } \\
\text { quarter/year. Source: Compustat. }\end{array}$ \\
\hline Cash Flow & $\frac{\mathrm{EBIT}_{t}}{\text { total }_{\text {assets }}}$ & $\begin{array}{l}\text { EBIT is earnings after interest and taxes but be- } \\
\text { fore depreciation. Source: Compustat. }\end{array}$ \\
\hline Industry Sigma & Cash-flow risk & $\begin{array}{l}\text { Average standard deviation of corporates' cash } \\
\text { flow within the same two-digit SIC code (min. } 3 \\
\text { obs.). Source: Compustat. }\end{array}$ \\
\hline Net Working Capital & $\frac{(\text { Net working capital }- \text { Cash })_{t}}{\text { Total assets } t}$ & $\begin{array}{l}\text { The amount of working capital net of corporate } \\
\text { cash holdings. Source: Compustat. }\end{array}$ \\
\hline R\&D/Sales & $\frac{\mathrm{R} \& \mathrm{D}_{t}}{\text { Total sales }}$ & $\begin{array}{l}\text { Cost related to Research and Development. } \\
\text { Source: Compustat. }\end{array}$ \\
\hline Capital Expenditure & $\frac{\text { Capital expenditures }_{t}}{\text { Total assets }}$ & Corporate capital spending. Source: Compustat. \\
\hline Acquisition Activity & $\frac{\text { Acquisition }_{t}}{\text { Total assets }}$ & $\begin{array}{l}\text { The amount used for M\&A activities. Source: } \\
\text { Compustat. }\end{array}$ \\
\hline Dividends & Dummy & $\begin{array}{l}\text { The variable is equal to } 0 \text { if the corporate has } \\
\text { positive dividends in a given quarter/year, and } 0 \\
\text { otherwise. Source: Compustat. }\end{array}$ \\
\hline Rated & Dummy & $\begin{array}{l}\text { The variable is equal to } 0 \text { if the corporate has } \\
\text { a rating, and } 0 \text { otherwise. Source: S\&P Capital } \\
\text { IQ. }\end{array}$ \\
\hline Investment Rating & & $\mathrm{S} \& \mathrm{P}$ rating of BBB- or higher. Source: Markit. \\
\hline Sales & $\log (\mathrm{EBIT})$ & $\begin{array}{l}\text { Operating income before interest and taxes (after } \\
\text { depreciation). Source: Compustat. }\end{array}$ \\
\hline Competition & $\begin{array}{l}\text { Herfindahl-Hirschmann } \\
\text { index }(\mathrm{HHI})\end{array}$ & $\begin{array}{l}\text { The Herfindahl-Hirschmann index (HHI) mea- } \\
\text { suring the industry competition ande determined } \\
\text { as the squared sum of market shares within in- } \\
\text { dustries using the corporates' sales. Source: } \\
\text { Compustat. }\end{array}$ \\
\hline Bank Debt & $\frac{\text { Bank Debt }}{\text { Total Assets }_{t}}$ & $\begin{array}{l}\text { Bank debt is the amount of debt from bank loans. } \\
\text { Source: Capital IQ }\end{array}$ \\
\hline Sovereign CDS & 5-year CDS spread & $\begin{array}{l}\text { The variable is the end-of-quarter observation } \\
\text { of the countries' } 5 \text {-year CDS spreads. Source: } \\
\text { Markit. }\end{array}$ \\
\hline Corporate Tax & Corporate tax rate & $\begin{array}{l}\text { The measure reflect the country specific corpo- } \\
\text { rate tax rates, given on a quarterly basis. Source: } \\
\text { ECB Statistical Data Warehouse. }\end{array}$ \\
\hline Government Investment & $\begin{array}{l}\text { Investment expenditures } \\
\text { by governments, scaled by } \\
\text { GDP. }\end{array}$ & $\begin{array}{l}\text { The measure is determined as the local govern- } \\
\text { ments spending on investments, scaled by GDP } \\
\text { and given on a quarterly basis. Source: ECB } \\
\text { Statistical Data Warehouse. }\end{array}$ \\
\hline Government Debt & $\begin{array}{l}\text { Government Debt }(\% \text { of } \\
\text { GDP, by quarter })\end{array}$ & Source: ECB Statistical Data Warehouse. \\
\hline Early LTRO Repayment & $\frac{\Delta \text { LTRO Holdings }}{2012 t o 2013, \mathrm{NCB}}$ & $\begin{array}{l}\text { Source: National Central Bank Reports and } \\
\text { Bloomberg }\end{array}$ \\
\hline
\end{tabular}

This table provides descriptions of all the variables used in the analyses. All financial variables are winsorized at the 1st and 99th percentiles, and in our empirical specifications we use ratios given in percentages. 
Table A4

Export, competition and LTRO uptake effect on investment

\begin{tabular}{|c|c|c|c|c|}
\hline & \multicolumn{2}{|c|}{ Investments } & \multicolumn{2}{|c|}{ Investments } \\
\hline & $\begin{array}{c}\text { Low Export } \\
(1) \\
\end{array}$ & $\begin{array}{c}\text { High Export } \\
(2) \\
\end{array}$ & $\begin{array}{c}\text { High Competition } \\
(3) \\
\end{array}$ & $\begin{array}{c}\text { Low Competition } \\
(4) \\
\end{array}$ \\
\hline LTRO-Country Uptake & $\begin{array}{c}-1.504^{* * *} \\
(0.26)\end{array}$ & $\begin{array}{c}-0.411 \\
(0.59)\end{array}$ & $\begin{array}{c}-1.575^{* * *} \\
(0.27)\end{array}$ & $\begin{array}{c}-1.324^{* * *} \\
(0.43)\end{array}$ \\
\hline Cash Flow & $\begin{array}{c}0.006^{* * *} \\
(0.00)\end{array}$ & $\begin{array}{c}0.009^{* * *} \\
(0.00)\end{array}$ & $\begin{array}{c}0.010^{* * *} \\
(0.00)\end{array}$ & $\begin{array}{c}-0.000 \\
(0.00)\end{array}$ \\
\hline Market-to-Book & $\begin{array}{c}0.004^{* * *} \\
(0.00)\end{array}$ & $\begin{array}{c}0.004^{* * *} \\
(0.00)\end{array}$ & $\begin{array}{c}0.003^{* * *} \\
(0.00)\end{array}$ & $\begin{array}{c}0.005^{* * *} \\
(0.00)\end{array}$ \\
\hline Size & $\begin{array}{c}-0.013 \\
(0.04)\end{array}$ & $\begin{array}{c}0.467 * * * \\
(0.06)\end{array}$ & $\begin{array}{c}0.302^{* * *} \\
(0.04)\end{array}$ & $\begin{array}{c}0.472^{* * *} \\
(0.06)\end{array}$ \\
\hline Leverage & $\begin{array}{c}-0.013^{* * *} \\
(0.00)\end{array}$ & $\begin{array}{c}-0.015^{* * *} \\
(0.00)\end{array}$ & $\begin{array}{c}-0.013^{* * *} \\
(0.00)\end{array}$ & $\begin{array}{c}-0.022^{* * *} \\
(0.00)\end{array}$ \\
\hline Rated & $\begin{array}{l}0.194 \\
(0.14)\end{array}$ & $\begin{array}{c}0.721^{* * *} \\
(0.26)\end{array}$ & $\begin{array}{l}0.167 \\
(0.14)\end{array}$ & $\begin{array}{c}0.569^{* * *} \\
(0.21)\end{array}$ \\
\hline Sovereign CDS & $\begin{array}{c}-0.680^{* * *} \\
(0.10)\end{array}$ & $\begin{array}{c}-1.740 \\
(4.06)\end{array}$ & $\begin{array}{c}-0.623^{* * *} \\
(0.11)\end{array}$ & $\begin{array}{c}-0.786^{* * *} \\
(0.19)\end{array}$ \\
\hline Sovereign Export & $\begin{array}{c}-0.070 * * * \\
(0.00)\end{array}$ & $\begin{array}{l}0.011 \\
(0.00)\end{array}$ & $\begin{array}{c}-0.015^{* *} \\
(0.00)\end{array}$ & $\begin{array}{c}-0.009 \\
(0.01)\end{array}$ \\
\hline Time fixed effects & Yes & Yes & Yes & Yes \\
\hline Firm fixed effects & Yes & Yes & Yes & Yes \\
\hline$R$-square & 0.591 & 0.625 & 0.625 & 0.660 \\
\hline$N$ & 61206 & 25186 & 55646 & 30363 \\
\hline
\end{tabular}

This table presents estimates of the effect of demand uncertainty, product supply and the liquidity uptake from the ECB's three-year Longer-term Refinancing Operations (LTROs) on corporate investment in a sample of corporations located in the Eurozone. Our measure for corporates' investment is Capital Expenditure, which is the corporate capital expenditure scaled by total assets. The variable LTRO-Country Uptake is equal to zero until Q4-2011, and equal to the country-specific total LTRO uptake amount, scaled by the central government debt of the country, thereafter. In Models 1 and 2, corporations are separated into those with low and high sovereign exports, based on the home countries' exports-to-GDP ratio. The export data are on a yearly basis. High (Low) Export is defined as an export-to-GDP ratio above (below) the median in a given year. In Models 3 and 4, corporations are separated into those with high and low industry competition, based on the corporates' SIC-code classifications and the related industry's Herfindahl-Hirschman index (HHI). The HHI is given by the sum of the squared market shares of corporates within the same industry, for each given year. High (Low) Competition is defined by an HHI below (above) the median in a given year. The sample period is 2002-2014, based on quarterly observations. (*** denotes significance at the $1 \%$ level, ${ }^{* *}$ significance at the $5 \%$ level, and $*$ significance at the $10 \%$ level. The numbers in parentheses are standard errors.) 
Table A5

Summary statistics for sample of Eurozone corporations with existing loan information from LPC Dealscan

\begin{tabular}{|c|c|c|c|c|c|c|c|c|c|c|c|c|}
\hline Country & $\mathrm{DEU}$ & FRA & ITA & GRC & NLD & FIN & ESP & BEL & AUT & IRL & PRT & Total \\
\hline Cash & 8.49 & 8.97 & 7.36 & 4.44 & 6.84 & 5.41 & 6.71 & 6.73 & 8.20 & 9.49 & 4.17 & 7.65 \\
\hline Leverage & 22.0 & 24.3 & 30.3 & 42.6 & 25.1 & 27.8 & 32.6 & 26.8 & 26.4 & 30.2 & 39.0 & 26.5 \\
\hline Net Debt & 60.7 & 63.4 & 69.2 & 66.4 & 62.0 & 60.1 & 66.9 & 61.4 & 55.4 & 62.5 & 72.5 & 62.9 \\
\hline Short-term Debt & 0.05 & 0.05 & 0.10 & 0.15 & 0.04 & 0.08 & 0.08 & 0.05 & 0.08 & 0.03 & 0.08 & 0.06 \\
\hline Investments & 3.92 & 3.34 & 2.97 & 3.45 & 3.25 & 3.76 & 3.26 & 4.06 & 5.82 & 2.98 & 5.61 & 3.55 \\
\hline Wages & 3.10 & 3.62 & 3.34 & 2.35 & 3.83 & 3.93 & 3.96 & 2.90 & 3.76 & 2.01 & 4.12 & 3.43 \\
\hline Size & 6.32 & 6.82 & 6.60 & 5.90 & 7.21 & 6.83 & 7.09 & 6.52 & 6.53 & 7.18 & 7.82 & 6.72 \\
\hline Market-to-Book & 119 & 120 & 115 & 98.5 & 130 & 121 & 118 & 115 & 122 & 143 & 121 & 119 \\
\hline Cash Flow & 4.93 & 4.07 & 3.71 & 2.12 & 5.74 & 6.77 & 6.08 & 5.17 & 5.71 & 3.12 & 5.94 & 4.72 \\
\hline Industry Sigma & 6.43 & 5.04 & 3.01 & 2.75 & 4.50 & 4.07 & 2.53 & 4.76 & 3.30 & 2.80 & 2.78 & 4.44 \\
\hline Net Working Capital & 5.93 & -2.3 & -0.4 & 0.43 & 1.72 & 3.64 & -1.6 & -2.6 & 8.06 & 0.36 & -8.4 & 1.11 \\
\hline R\&D/Sales & 0.02 & 0.00 & 0.00 & 0.00 & 0.00 & 0.52 & 0.00 & 0.00 & 0.43 & 0.00 & 0.00 & 0.00 \\
\hline Acquisition Activity & 0.00 & 0.00 & 0.00 & 0.00 & 0.21 & 0.03 & 0.00 & 0.00 & 0.00 & 0.00 & 0.00 & 0.00 \\
\hline Bank Debt & 10.3 & 9.62 & 21.0 & 23.0 & 12.7 & 13.0 & 25.3 & 11.6 & 17.3 & 13.6 & 11.8 & 13.4 \\
\hline \# Observations & 1076 & 1000 & 3700 & 2015 & 3816 & 2473 & 2993 & 2039 & 1084 & 1232 & 475 & 4059 \\
\hline $\begin{array}{l}\text { \# Corporations } \\
\text { \# LTRO- }\end{array}$ & 245 & 238 & 93 & 43 & 101 & 54 & 70 & 43 & 24 & 32 & 10 & 953 \\
\hline Bank Rel. & 122 & 111 & 57 & 9 & 52 & 18 & 48 & 25 & 11 & 16 & 7 & 476 \\
\hline
\end{tabular}

This table presents sample characteristics of corporations a subsample of Eurozone corporations with existing loan information in LPC Dealscan. The table provides for each country sample averages (medians) of corporate characteristics. \# LTRO-Bank Rel. is the number of corporations that in the five years prior to the first LTRO intervention had a loan relation to a Eurozone bank that participated in the three-year LTROs as of December 2011 and February 2012. Cash is the ratio of cash and shortterm investments to total assets. Investment is the ratio of capital expenditure to total assets. Wages is the total salaries and wages, given in logarithms. Leverage is measured as the book value of the long-term debt plus debt in current liabilities, divided by total assets. Net Debt is defined as the ratio of current plus non-current liabilities minus cash holdings to total assets. Short-term Debt is defined as the ratio of current liabilities to total assets. Bank Debt is the amount of debt from bank loans, divided by total assets. Size is the logarithm of total assets. Market-to-Book is the book value of assets minus the book value of equity plus the market value of equity, all divided by the book value of assets. Cash Flow is the ratio of the cash flow to total assets, where cash flow is defined as the earnings after interest and related expenses, income taxes, and dividends. Industry Sigma is industry cash flow risk, measured by the mean cash flow volatility across two-digit SIC codes. Net Working Capital is measured as the difference between current assets and current liabilities net of cash, divided by total assets. RED/Sales is the ratio of R\&D to sales. Acquisition Activity is the ratio of acquisitions to total assets. Industry Competition is the Herfindahl-Hirschmann Index (HHI) industry competition measure. The sample period for each country is 2002-2014, and the variables are based on quarterly corporate fundamental observations. For any data unavailable for a specific quarter, we replace the missing values with the yearly observations. Ratios are given in percentages. The firm fundamental data are obtained from Compustat Global, while country specific data are obtained from Markit, the World Bank, as well as, the ECB statistics Warehouse. The loan information data is obtained from LPC Dealscan. 
Table A6

Total LTRO holdings by National Central Banks

\begin{tabular}{|c|c|c|c|c|c|}
\hline \multirow[b]{3}{*}{ Country } & \multicolumn{4}{|c|}{ Total LTRO Holdings } & \multirow{3}{*}{$\begin{array}{c}\text { Repayment Ratio } \\
2012 \text { to } 2013 \\
\% \\
(5)\end{array}$} \\
\hline & 2010 & 2011 & 2012 & 2013 & \\
\hline & $\begin{array}{c}\text { EUR billion } \\
\text { (1) }\end{array}$ & $\begin{array}{c}\text { EUR billion } \\
(2)\end{array}$ & $\begin{array}{c}\text { EUR billion } \\
(3)\end{array}$ & $\begin{array}{c}\text { EUR billion } \\
\text { (4) }\end{array}$ & \\
\hline Austria & 3.49 & 7.18 & 15.71 & 5.87 & -62.62 \\
\hline Belgium & 4.12 & 17.97 & 39.92 & 14.29 & -64.22 \\
\hline France & 20.22 & 123.14 & 172.88 & 61.53 & -64.41 \\
\hline Germany & 33.46 & 47.11 & 69.65 & 13.77 & -80.23 \\
\hline Greece & 78.38 & 60.94 & 1.95 & 1.39 & -28.79 \\
\hline Ireland & 56.03 & 76.29 & 63.09 & 34.50 & -45.31 \\
\hline Italy & 31.01 & 160.61 & 268.30 & 213.71 & -20.35 \\
\hline Netherlands & 0.92 & 3.19 & 24.48 & 8.81 & -63.99 \\
\hline Portugal & 22.97 & 39.03 & 49.26 & 42.69 & -13.33 \\
\hline Spain & 39.66 & 156.68 & 315.35 & 178.06 & -43.53 \\
\hline Total & 290.26 & 692.13 & 1020.58 & 574.62 & -43.70 \\
\hline
\end{tabular}

This table presents the holdings and repayment of longer-term refinancing operations (LTROs) by National Central Banks (NCB) in the Eurozone. The Total LTRO Holdings include all longer-term refinancing operations, i.e., the three-month to the three-year longer-term refinancing pperations initiated by the European Central Bank (ECB) on December 21, 2011 (LTRO I) and February 29, 2012 (LTRO II), respectively, and are end-of year values. In column 5, the table outlines the percentage change in the total LTRO holdings by national central banks from 2012 to 2013 . The information about the national central bank LTRO holdings is based upon hand-collected data from the national central banks websites. 
Table A7

Uptake and early repayment of LTRO and firm size effect on corporate investments

\begin{tabular}{|c|c|c|c|c|c|c|}
\hline \multicolumn{7}{|c|}{ Panel A: Low early LTRO repayment } \\
\hline & \multicolumn{2}{|c|}{ Cash } & \multicolumn{2}{|c|}{ Leverage } & \multicolumn{2}{|c|}{ Investments } \\
\hline & $\begin{array}{c}\text { Small } \\
(1)\end{array}$ & $\begin{array}{c}\text { Large } \\
(2)\end{array}$ & $\begin{array}{c}\text { Small } \\
(3)\end{array}$ & $\begin{array}{c}\text { Large } \\
(4)\end{array}$ & $\begin{array}{l}\text { Small } \\
(5)\end{array}$ & $\begin{array}{c}\text { Large } \\
(6)\end{array}$ \\
\hline LTRO-Bank Uptake & $\begin{array}{c}-7.418 \\
(6.04)\end{array}$ & $\begin{array}{c}6.419^{* * *} \\
(1.82)\end{array}$ & $\begin{array}{c}30.849 * * * \\
(10.3)\end{array}$ & $\begin{array}{c}16.826 * * * \\
(2.65)\end{array}$ & $\begin{array}{c}13.449 * * * \\
(3.83)\end{array}$ & $\begin{array}{c}-3.204^{* * *} \\
(0.81)\end{array}$ \\
\hline$R$-square & 0.668 & 0.613 & 0.746 & 0.774 & 0.519 & 0.618 \\
\hline$N$ & 2633 & 1907 & 2633 & 1907 & 2740 & 2003 \\
\hline
\end{tabular}

Panel B: Medium early LTRO repayment

\begin{tabular}{|c|c|c|c|c|c|c|}
\hline & \multicolumn{2}{|c|}{ Cash } & \multicolumn{2}{|c|}{ Leverage } & \multicolumn{2}{|c|}{ Investments } \\
\hline & $\begin{array}{l}\text { Small } \\
(1)\end{array}$ & $\begin{array}{l}\text { Large } \\
(2)\end{array}$ & $\begin{array}{c}\text { Small } \\
(3)\end{array}$ & $\begin{array}{l}\text { Large } \\
(4)\end{array}$ & $\begin{array}{c}\text { Small } \\
(5)\end{array}$ & $\begin{array}{l}\text { Large } \\
(6)\end{array}$ \\
\hline LTRO-Bank Uptake & $\begin{array}{l}-0.72 \\
(0.56)\end{array}$ & $\begin{array}{c}-0.898^{* * *} \\
(0.21)\end{array}$ & $\begin{array}{c}2.419^{* * *} \\
(0.80)\end{array}$ & $\begin{array}{c}-1.502^{* * *} \\
(0.31)\end{array}$ & $\begin{array}{c}-0.617^{* *} \\
(0.25)\end{array}$ & $\begin{array}{c}-0.413^{* * *} \\
(0.12)\end{array}$ \\
\hline$R$-square & 0.784 & 0.743 & 0.733 & 0.824 & 0.577 & 0.683 \\
\hline$N$ & 6996 & 8980 & 6996 & 8980 & 7299 & 9349 \\
\hline
\end{tabular}

Panel C: High early LTRO repayment

\begin{tabular}{|c|c|c|c|c|c|c|}
\hline & \multicolumn{2}{|c|}{ Cash } & \multicolumn{2}{|c|}{ Leverage } & \multicolumn{2}{|c|}{ Investments } \\
\hline & $\begin{array}{c}\text { Small } \\
(1)\end{array}$ & $\begin{array}{c}\text { Large } \\
(2)\end{array}$ & $\begin{array}{l}\text { Small } \\
(3)\end{array}$ & $\begin{array}{c}\text { Large } \\
(4)\end{array}$ & $\begin{array}{c}\text { Small } \\
(5)\end{array}$ & $\begin{array}{c}\text { Large } \\
(6)\end{array}$ \\
\hline LTRO-Bank Uptake & $\begin{array}{l}7.164 \\
(19.7)\end{array}$ & $\begin{array}{c}17.134^{*} \\
(9.68)\end{array}$ & $\begin{array}{c}-40.075^{*} \\
(21.1)\end{array}$ & $\begin{array}{l}0.287 \\
(12.2)\end{array}$ & $\begin{array}{c}14.495^{* *} \\
(7.00)\end{array}$ & $\begin{array}{c}8.388^{*} \\
(4.71)\end{array}$ \\
\hline$R$-square & 0.716 & 0.622 & 0.749 & 0.799 & 0.568 & 0.591 \\
\hline$N$ & 4683 & 3961 & 4683 & 3961 & 4853 & 4113 \\
\hline
\end{tabular}

This table presents estimates of the effect of the liquidity uptake from the ECB's three-year Longer-term Refinancing Operations (LTROs) by loan-related banks, and LTRO repayment policies and corporations size on corporate polices, in a subsample of Eurozone corporations with existing loan information in LPC Dealscan. The variable LTRO-Bank Uptake is equal to zero until Q4-2011, and equal to the LTRO uptake amount of the corporate's related banks, scaled by the size of each bank, thereafter. In Panels A through Panels C corporations are separated based on their location and the respective country's LTRO repayment policy, compared to the initial LTRO-country uptake. Low (Medium, High) early LTRO repayment is defined as a LTRO repayment ratio from 2012 to 2013, i.e., at the first possible LTRO repayment date, that is below 30\% (between 30\% and $70 \%$, above $70 \%$ ). Further, corporations are separated into small and large corporations, where Small (Large) refers to corporations with an asset value one year before the LTRO intervention, 2010-Q4, below (above) the medium value. The sample period is 2002-2014, and based on quarterly observations. Control variables, as well as, firm and time fixed effects are included in all specifications. (*** denotes significance at the $1 \%$ level, ${ }^{* *}$ significance at the $5 \%$ level, and $*$ significance at the $10 \%$ level. The numbers in parentheses are standard errors.) 